RODRIGO VIDAL NITRINI

Liberdade de informação e proteção ao sigilo de fonte: desafios constitucionais na era da informação digital

DISSERTAÇÃO DE MESTRADO

Professor Titular Virgílio Afonso da Silva

Orientador

UNIVERSIDADE DE SÃO PAULO

FACULDADE DE DIREITO

SÃO PAULO - 2013 
RODRIGO VIDAL NITRINI

\section{Liberdade de informação e proteção ao sigilo de fonte: desafios constitucionais na era da informação digital}

DISSERTAÇÃO DE MESTRADO

Dissertação apresentada como requisito parcial à obtenção do grau de Mestre em Direito pelo Programa de Pós-Graduação da Faculdade de Direito da Universidade de São Paulo

Área de Concentração: Direito do Estado

Orientador: Professor Titular Virgílio Afonso da Silva

UNIVERSIDADE DE SÃO PAULO

FACULDADE DE DIREITO SÃO PAULO - 2013 
Banca Examinadora:

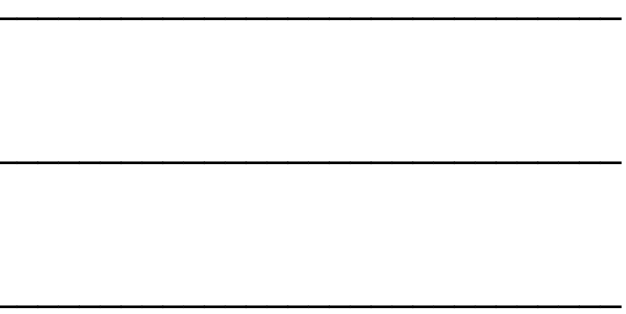


Aos meus pais,

Dacio e Tania,

e à Mariana Beatriz 


\section{Agradecimentos}

A sessão inicial de agradecimentos em um trabalho acadêmico é rotineira, e pode parecer apenas um clichê burocrático, que retarda o encontro do leitor com o sumário. Ao menos isso é o que já passou pela minha cabeça, algumas vezes.

Mas ao entregar a versão final desta dissertação, percebo que é inevitável relembrar o percurso dos últimos anos e, então, agradecer a quem tornou esse período no programa de pós-graduação bastante enriquecedor e prazeroso.

Agradeço ao orientador Virgílio Afonso da Silva, primeiro, pela confiança depositada no meu projeto de pesquisa inicial e, principalmente, pela disposição com que trabalha para assegurar que o mestrado não seja equivalente a uma dissertação, mas a um processo de formação acadêmica em um ambiente de discussões críticas e livres. A organização das turmas de monitoria na graduação, dos seminários mensais de pesquisa em direito constitucional e das confraternizações em mesas de bares foram cruciais para isso.

Aos professores Eugênio Bucci e Octávio Luiz Motta Ferraz, agradeço a gentileza de terem aceitado o convite para a composição da banca de qualificação. Deles, assim como dos professores Diogo Coutinho e Marcos Paulo Veríssimo, recebi valiosas críticas e sugestões, após uma leitura atenta de versões iniciais da pesquisa.

Os colegas alunos com quem convivi nos últimos dois anos tornaram esse trajeto não apenas mais fácil, mas muito mais interessante. Agradeço a todos pelo clima de camaradagem, bom-humor e colaboração mútua - e, em especial, a Caroline Medeiros, Paula Gorzoni, Flávio Beicker, Adriana Vojvodic, Rafael Lima, Daniel Wang, Fabio Oliveira, Luciana de Oliveira Ramos, Leonardo Orth, Natália Pires, Luiza Corrêa e Dennys Antonialli.

Aos colegas da Defensoria Pública de SP e da equipe de sua Coordenadoria de Comunicação Social, agradeço o apoio com que sempre posso contar.

Aos amigos de sempre, obrigado pelo essencial de sempre - vocês sabem quem são!

Aos meus pais e à Mabe tenho tanto a agradecer que o mínimo que posso fazer é dedicar a eles o resultado de tudo isso. 


\section{Resumo}

Este trabalho procura debater a liberdade constitucional de informação sob um viés não usual ao direito constitucional brasileiro.

Seu ponto de partida é a proteção ao sigilo de fonte para jornalistas profissionais, consagrada pelo texto constitucional. Essa regra parece pressupor uma distinção possível e clara entre jornalistas e demais cidadãos.

Mas como compreendê-la em um cenário atual no qual: a) as condições tecnológicas permitem que qualquer cidadão, a um custo baixo ou quase inexistente, publique informações para um número indistinto de pessoas, e; b) o Supremo Tribunal Federal tenha reconhecido que o Estado não pode exigir a obtenção de um diploma de ensino superior para diferenciar a categoria de jornalistas?

Logo, o pano de fundo deste trabalho é a possibilidade de o Estado diferenciar jornalistas de demais cidadãos com relação à concessão de prerrogativas para o exercício da liberdade de informação.

Nos Estados Unidos, esse é um debate relevante ao menos desde a década de 1970. São apresentados seus principais aspectos: por um lado, a jurisprudência de sua Suprema Corte, que se negou sistematicamente a diferenciar direitos próprios à liberdade de imprensa ("Press Clause") em comparação com a liberdade de expressão ("Speech Clause"); por outro, as abordagens "funcional" e "institucional" à liberdade de imprensa, composta respectivamente por autores favoráveis e críticos àquela linha jurisprudencial.

Ao final, a partir de uma perspectiva crítica e da adoção de fundamentos jurídicos, busca-se analisar a regra constitucional do sigilo de fonte e propor parâmetros interpretativos para sua aplicação.

Palavras-chave: liberdade de informação, liberdade de imprensa, liberdade de expressão, jornalismo, sigilo de fonte, interpretação constitucional. 


\section{Abstract}

This paper seeks to debate the constitutional freedom of information under an aspect not common to Brazilian constitutional law.

The departure point is the reporter's privilege, constitutionally protected for professionals by law. That rule seems assume a possible and clear distinction between journalists and other citizens.

But how to understand it under a scenario where: a) the technological conditions allow any citizen, with very cheap or barely existing costs, to publish information for an indistinct number of people, and; b) the Supreme Federal Court has recognized that the State may not license journalists by a college degree diploma?

Thus, the background subject of this paper is the possibility that the State differentiates journalists from other citizens in regard to the concession of prerogatives for the exercise of the freedom of information.

In the United States, this has been a relevant debate at least since de 1970s. The main aspects are presented: on one hand, the Supreme Court's case law that has systematically denied to differentiate exclusive rights deriving from the Press Clause in comparison to the Speech Clause; on the other hand, the "functional" and "institutional" approaches to freedom of the press, respectively representing the authors favorable and critics to that judicial construction.

Finally, taking on from a critic perspective and adopting legal fundaments, it seeks to analyze the constitutional rule of the reporter's privilege and to propose interpretative standards for it.

Keywords: freedom of information, freedom of press, freedom of speech, journalism, reporter's privilege, constitutional interpretation 
Capítulo 1

Introdução.

1.a - Tema a ser desenvolvido e suas limitações.

10

1.b - Pressupostos teóricos do trabalho: direitos fundamentais como princípios jurídicos

Capítulo 2

Uma breve contextualização histórica .19

2.a - Liberdade de impressão . .19

2.b - Liberdade de expressão .23

2.c - A imprensa profissional. .25

2.d - Informações e expressões em rede. .28

2.e - Considerações finais do capítulo. 30

Capítulo 3

A liberdade de imprensa no direito constitucional norte-americano: o papel da press clause para sua Suprema Corte. .31

3.a - A imprensa "auto-evidente" das primeiras décadas do século XX......................32

3.b - New York Times Co. v. Sullivan (1964)...........................................................33

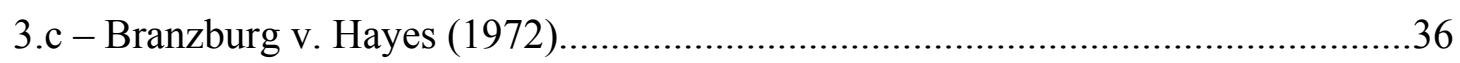

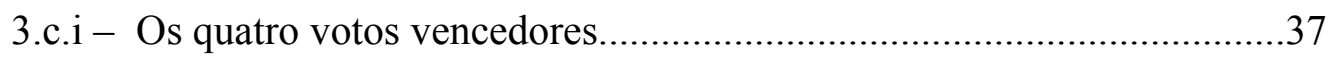

3.c.ii - O quinto e influente voto de minerva de Powell...................................38

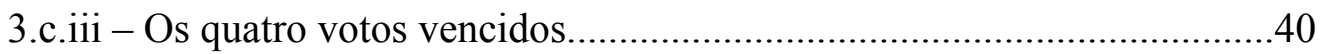

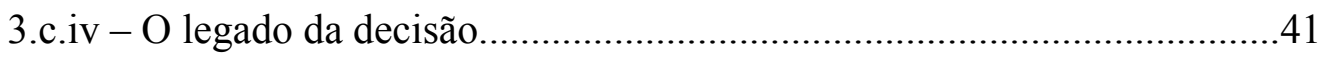

3.d - Landmark Communications v. Virginia (1978)...............................................43

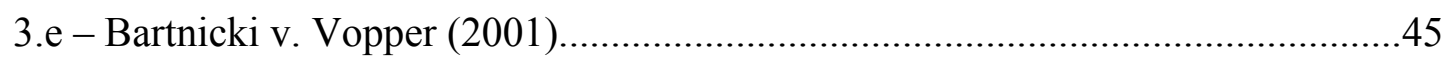

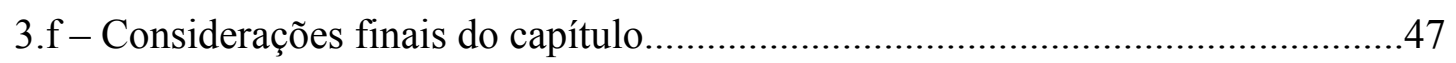

Capítulo 4

Liberdade de imprensa: as abordagens "institucional" e "funcional".................48

4.a - Os modelos de impresa livre ("free press") e imprensa aberta (“open press")..48

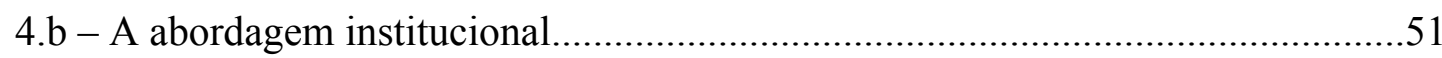


4.b.i - Os argumentos de Potter Stewart...........................................................52

4.b.ii - Os argumentos de Frederick Schauer...................................................53

4.b.iii - Os argumentos de David Anderson...................................................56

4.b.iv - Os argumentos de Paul Horwitz.......................................................58

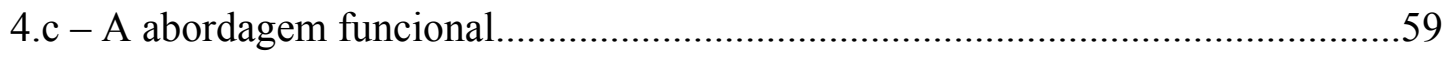

4.c.i. - Apresentação de casos da jurisprudência norte-americana..................62

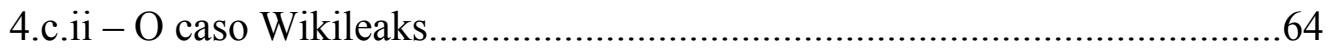

4.d - O julgamento do recurso extraordinário $n^{0} 511.961$ pelo STF e a afirmação de argumentos tendentes a um modelo de imprensa aberta.

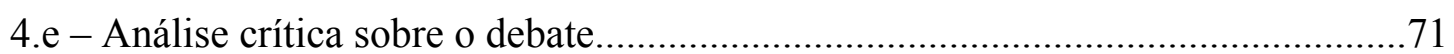

4.e.i. - Relevância jurídica versus relevância de fato.....................................74

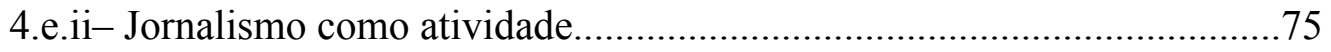

4.e.iii - Julgamento editorial e objetividade jornalística................................78

4.e.iv- Independência ou isenção jornalística? ..............................................80

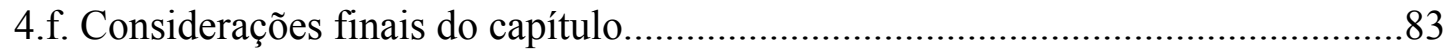

Capítulo 5

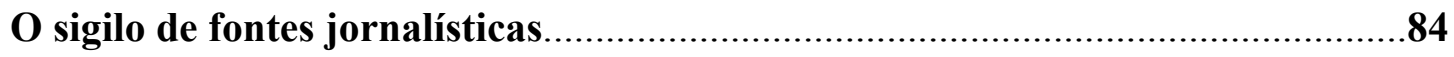

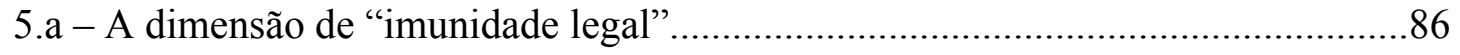

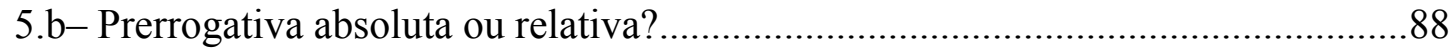

5.c - A proteção ao sigilo de fonte na Constituição brasileira: uma proposta interpretativa sob a abordagem funcional à liberdade de imprensa............................95

5.d - Critérios para a expansão do sigilo de fonte......................................................97

5.d.i - O'Grady v. Superior Court of Santa Clara (2006) ...............................98

5.d.ii - Too Much media LLC v. Hale (2011) ..............................................99

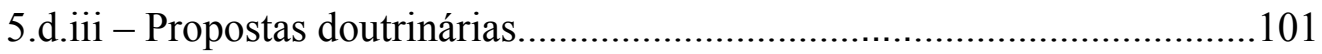

5.d.iv - Perspectiva crítica e propostas........................................................104

5.e - A possibilidade de criação de regras pelo legislativo.........................................106

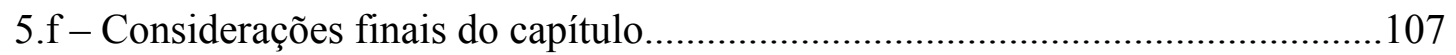

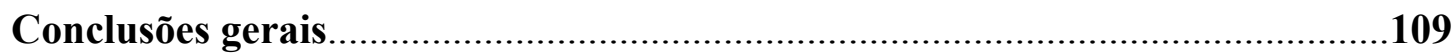

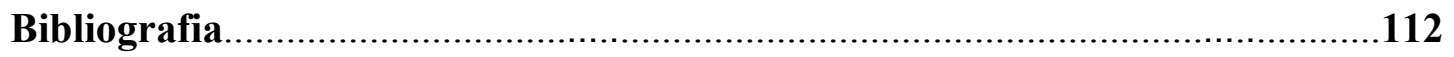




\section{Capítulo 1 - Introdução}

\section{1.a - Tema a ser desenvolvido e suas limitações}

A Constituição brasileira enuncia em seu art. $5^{\circ}$, inciso XIV, ser "assegurado a todos o acesso à informação e resguardado o sigilo da fonte, quando necessário ao exercício profissional". Embora esse dispositivo não seja normalmente objeto de grandes controvérsias, é possível tomá-lo como ponto de partida para relevantes debates que costumam passar ao largo de discussões sobre os temas "liberdade de imprensa" ou "liberdade de informação".

O exercício da liberdade de informação e a proteção ao sigilo de fonte encaram um atual quadro de realidade social que implica a necessidade de se refletir sobre as compreensões tradicionais desses direitos, com consequentes desafios em sede de interpretação constitucional. Há dois fundamentos em especial que justificam esse cenário.

Em junho de 2009, o Supremo Tribunal Federal decidiu ser inconstitucional a exigência formal de diploma em curso superior de jornalismo para o exercício dessa atividade. A corte entendeu que o requisito, previsto no decreto-lei $\mathrm{n}^{\circ} 972$ de 1969, não foi recepcionado pela Constituição de 1988, pois constituía um embaraço injustificado às liberdades de expressão e de informação pelos cidadãos. $\mathrm{O}$ tribunal apontou, ainda, violações a dispositivos correlatos da Convenção Americana de Direitos Humanos ${ }^{1}$.

A decisão nivelou o Brasil com significativas democracias constitucionais, onde o exercício da atividade de jornalismo sempre prescindiu de formação específica. Historicamente, pessoas sem formação superior ou habilitadas em outros campos do saber - como direito, história, economia, medicina, entre demais áreas sempre puderam exercer o jornalismo em veículos de imprensa ${ }^{2}$.

\footnotetext{
${ }^{1}$ Recurso extraordinário $\mathrm{n}^{\mathrm{o}}$ 511.961, julgado em 17.11.2009. A decisão será analisada no capítulo 4 ${ }^{2}$ Exemplificativamente: Alemanha, Argentina, Austrália, Áustria, Bélgica, Estados Unidos, Espanha, França, Inglaterra, Holanda, Finlândia, Grécia, Chile, Irlanda, Itália, Japão, Suécia e Suíça não
} 
Paralelamente, a última década consolidou uma irreversível revolução tecnológica que alterou profundamente o exercício da liberdade de informação e seu potencial. Durante o século XX, a comunicação em massa era atributo exclusivo de empresas da área - por meio de jornais impressos, rádio e televisão. A veiculação ampla de uma notícia ou opinião demandava estrutura e suporte físicos alcançados, em regra, apenas mediante investimentos substanciais.

A realidade hoje é outra. $\mathrm{O}$ avanço exponencial da internet e a popularização de suportes para informação em rede (smartphones, tablets, notebooks e televisão digital, como exemplos) permitem que qualquer cidadão expresse sua opinião e exerça sua liberdade de informação sem qualquer custo extraordinário e com a possibilidade de alcançar imediatamente um número indistinto de pessoas ${ }^{3}$.

Há blogs pessoais que possuem dezenas de milhares de leitores diários. Não é raro que veículos tradicionais de imprensa repercutam assuntos discutidos há dias naquela difusa esfera digital. As últimas campanhas eleitorais em diversos países têm sido consideravelmente afetadas por essa mobilização informativa online.

"A História nos ensina que quando mídias antigas são confrontadas por outras mais novas, debates sobre a natureza das notícias e do jornalismo frequentemente

possuem a exigência do diploma, ao contrário de África do Sul, Congo, Arábia Saudita, Colômbia, Costa do Marfim, Croácia, Equador, Honduras, Indonésia, Síria, Tunísia, Turquia e Ucrânia - "Saiba que outros países exigem ou não o diploma de jornalismo", Portal UOL, reportagem publicada em 02.07.2009 < disponível em http://virgula.uol.com.br/ver/noticia/vestiba/2009/07/02/210121-saiba-queoutros-paises-exigem-ou-nao-o-diploma-de-jornalismo, último acesso em 27.12.2012>.

3 "Como essas características da era digital mudam as condições sociais para a liberdade de expressão? Diminuir os custos de transmissão, distribuição, criação e modificação de informações gera importantes efeitos democratizadores e descentralizadores. Pois também diminui os custos de formar comunidades de interesse, de interagir com pessoas, de fazer coisas novas a partir de velhas, de inovar, copiar, alterar e modificar, de distribuir as ideias de um indivíduo para um amplo número de pessoas. A mídia de massa que se desenvolveu no século XX é assimétrica - uma entidade falando para muitas pessoas, e é unidirecional - um transmissor envia informação pelo rádio ou pela televisão, mas esses aparelhos não podem ser usados para falar de volta (...). A Internet é bastante diferente. Não é nem assimétrica, nem unidirecional: muitas pessoas podem transmitir e falar de volta uma com as outras. Igualmente importante é que a Internet possibilita que você drible os intermediários e guardiões ("gatekeepers") da mídia de massa tradicional. Você pode publicar seu livro na Web. Você pode fazer seu próprio filme ou demo tape e distribuí-los em seu website. Você pode dizer o que quiser em seu próprio weblog" - Jack Balkin, "How Rights Change: Freedom of Speech in the Digital Era", Sidney Law Review 26 (2004), p. 3. 
surgem" ${ }^{4}$. Esse certamente é o caso dos vigorosos debates provocados pelas publicações do Wikileaks - um ótimo exemplo para ilustrar a discussão "o que é jornalismo" nos dias atuais. Não se discute apenas se o que esse website faz é jornalismo, mas também sobre se seus editores podem ser judicialmente compelidos a fornecerem suas fontes ou se têm o direito de invocar um direito de sigilo ${ }^{5}$.

Este trabalho, contudo, não pretende aderir a um tom de deslumbramento sobre o impacto da internet para a liberdade de informação e o jornalismo, em especial. Não são poucas as vozes críticas que problematizam atuais e possíveis consequências da difusão maciça de informações pela internet ${ }^{6}$.

De qualquer modo, as recentes condições tecnológicas motivam indagações sobre a conveniência de se tratar cidadãos não-profissionais como "imprensa". Em uma época em que não se sabe ao certo "quem" é o jornalista, aprofunda-se a discussão sobre a possibilidade de se diferenciar direitos e prerrogativas entre os “membros da imprensa" e cidadãos em geral". No limite, a proteção ao sigilo de fonte, por ser a mais aguda e complexa prerrogativa tradicionalmente reconhecida à imprensa, é o exemplo mais emblemático desse cenário ${ }^{8}$.

Há, portanto, um quadro atual quanto ao exercício da liberdade constitucional de informação, marcado pela reconhecida inconstitucionalidade da exigência formal de diploma em jornalismo e pela ampliação relevante das condições tecnológicas à disposição da sociedade, que muito diferem do cenário do século passado 9 .

\footnotetext{
${ }^{4}$ Scott Gant, We're All Journalists Now: The Transformation of the Press and Reshaping of the Law in the Internet Age. New York: Free Press, 2007, p. 38.

${ }^{5} \mathrm{O}$ caso Wikileaks será apresentado no capítulo 4 (item 4.c.ii).

${ }^{6}$ A esse respeito, ver capítulo 2 (item 2.d).

7 "Fim do diploma gera dúvidas sobre aplicação do direito de sigilo da fonte" - Portal Comunique-se $<w w w . c o m u n i q u e-s e . c o m . b r>$, reportagem publicada em 22.07.2009; David A. Logan, "A reporter's privilege for Twitterers", The Boston Globe, artigo publicado em 26.09.2006; "At a Suit's Core: Are Bloggers Reporters, too?", The New York Times, reportagem publicada em 07.03.2005; "Reporters Comitee asks court to apply reporter's privilege to Web Site”, The Reporter's Comitee for Freedom of the Press <www.rcfp.org>, texto publicado em 22.06.2009; "Blogger not covered by New Jersey shield law, court says", The Reporter's Comitee for Freedom of the Press <www.rcfp.org $>$, texto publicado em 06.07.2009.

${ }^{8} \mathrm{O}$ assunto será aprofundado no capítulo 5 .

${ }^{9}$ Esse quadro tecnológico é relevante porque potencializa a novos patamares o exercício da liberdade de informação na sociedade. Embora o cenário atual seja importante para as reflexões propostas por este trabalho, ele não é responsável pelas questões suscitadas: a possibilidade de o Estado diferenciar "quem é" a imprensa frente aos demais cidadãos, como será visto, é um debate que alcançou proeminência nos Estados Unidos ao longo da década de 170, muito antes do surgimento da internet. O
} 
É seguro dizer que uma diferenciação entre liberdade de imprensa (se compreendermos esse termo como historicamente referente às empresas de comunicação e seus profissionais) e liberdade de informação (se compreendida como um direito inerente à cidadania) é difícil e problemática - tanto por seus efeitos práticos quanto por suas identificações conceituais.

Este trabalho pretende discutir, como ponto de partida, a consistência de uma identificação conceitual nesse sentido. As obras de direito constitucional brasileiro costumam saudar a liberdade de imprensa sem atentar para as dificuldades inerentes à proposta de se diferenciar "quem é" ou não seu representante e "o que" ela faz a ponto de se diferenciar dos cidadãos em geral, tornando-se merecedora de prerrogativas constitucionais, legais e administrativas - exclusivas.

Como decorrência, propõe-se também a avaliar sob quais parâmetros deve ser compreendida a regra constitucional que garante o sigilo de fonte, enquanto proteção ao exercício da liberdade de informação, em um contexto de liberdade de informação na era digital - especialmente diante da ressalva "quando necessário ao exercício profissional" feita pelo texto constitucional.

A proteção ao sigilo de fonte é restrita a funcionários remunerados de empresas jornalísticas? Ou qualquer cidadão pode fazer uso dessa prerrogativa? O sigilo de fonte é decorrência do interesse público constante na suposta informação? O suporte da informação (jornal, livro, documentário, blog) é relevante? A decisão do STF em sede do recurso extraordinário $\mathrm{n}^{\mathrm{o}} 511.961$ fornece critérios constitucionais consistentes para abordar essas questões? Enfim, quais parâmetros interpretativos são adequados para uma compreensão da regra contida no art. $5^{\circ}$, inciso XIV, da nossa Constituição?

assunto gerou a publicações de artigos acadêmicos relevantes, especialmente após a decisão Branzburg v. Hayes pela Suprema Corte do país, em 1972 (ver capítulo 3 - item 3.c). É importante anotar, portanto, que não há uma relação de causalidade entre a liberdade de informação promovida pela internet e o tema deste trabalho - o que não afasta sua relevância, pelos motivos já apontados. Não é por outro motivo que, também nos Estados Unidos, o tema voltou à tona em publicações dos últimos anos. 
Os problemas aqui propostos, até onde se sabe, não foram abordados por obras de direito constitucional brasileiro.

É comum a doutrina apontar que a proteção constitucional ao exercício da liberdade de informação, ainda que em caráter individual, reflete e justifica-se pelo direito coletivo da sociedade ao livre fluxo de informações relevantes ${ }^{10}$. Quanto ao sigilo de fonte, em geral limita-se a saudar sua proteção constitucional como condição de efetiva liberdade de imprensa ${ }^{11}$. Essas considerações foram ressonadas pelo Supremo Tribunal Federal em despacho monocrático do ministro Celso de Mello sobre a proteção constitucional ao sigilo de fonte, datado de $1996^{12}$.

O direito comparado, entretanto, oferece perspectivas mais férteis para este projeto. O direito norte-americano, em especial, apresenta-se como um conveniente ponto de partida para essa discussão, em virtude de debates que subsistem naquele país há pelo menos quatro décadas.

Ao longo do século XX, especialmente durante sua segunda metade, a jurisprudência da Suprema Corte relegou a cláusula de liberdade de imprensa a uma irrelevância - ou redundância - posta ao lado da liberdade de expressão, no texto da Primeira Emenda ${ }^{13}$. Como será apresentado ao longo do capítulo 3, embora nenhuma decisão tenha enfrentado definitivamente essa questão, aquela corte constitucional

\footnotetext{
10 "É nesta [liberdade de informação jornalistica] que se centra a liberdade de informação, que assume características modernas, superadoras da velha liberdade de imprensa. Nela se concentra a liberdade de informar e é nela ou através dela que se realiza o direito coletivo à informação, isto é, a liberdade de ser informado" - José Afonso da Silva, Curso de Direito Constitucional Positivo. São Paulo: Malheiros, 20 ed., 2002, p. 245. No mesmo sentido: Luís Roberto Barroso, "Liberdade de expressão versus direitos da personalidade. Colisão de direitos fundamentais e critérios de ponderação", Temas de direito constitucional: Tomo III. Rio de Janeiro: Renovar, 2 ed., 2005, p. 103.

${ }^{11}$ Para um trabalho específico sobre o tema: Maria Cecília Labate Maiolini Rebello Pinho, O sigilo da fonte como garantia da liberdade de informação jornalística. Dissertação de mestrado apresentada à Faculdade de Direito da Universidade de São Paulo em 2007.

12 "Trata-se, na realidade, de expressiva garantia de ordem jurídica, que, outorgada a qualquer jornalista em decorrência de sua atividade profissional, destina-se, em última análise, a viabilizar, em favor da própria coletividade, a ampla pesquisa de fatos ou eventos cuja revelação se impõe como conseqüência ditada por razões de estrito interesse público. (...) Isso claramente significa que a prerrogativa concernente ao sigilo da fonte, longe de qualificar-se como mero privilégio de ordem pessoal ou estamental, configura, na realidade, meio essencial de concretização do direito constitucional de informar, revelando-se oponível, em conseqüência, a quaisquer órgãos ou autoridades do Poder Público, não importando a esfera em que se situe a atuação institucional dos agentes estatais interessados" (Inquérito $\mathrm{n}^{\mathrm{0}} 870-2$, grifos no original).

13 "Congress shall make no law respecting an establishment of religion, or prohibiting the free exercise thereof; or abridging the freedom of speech, or of the press; or the right of the people peaceably to assemble, and to petition the Government for a redress of grievances".
} 
negou sistematicamente o reconhecimento de qualquer prerrogativa especial à imprensa em comparação à liberdade de expressão comumente gozada pelos cidadãos - um cenário que gerou considerável polêmica acadêmica.

A jurisprudência norte-americana possui diversos precedentes, ainda, nos quais se discutiu se o sigilo de fonte de informação aplica-se também a diretores de documentários, autores de livros investigativos, escritores free-lancers, acadêmicos, entre outros - cujas razões fornecem sólidos parâmetros para o tema deste trabalho.

Embora o direito norte-americano tenha em larga medida enfrentado problemas resultantes desse tema, no Brasil o sigilo de fonte decorre de regra disposta pelo art. $5^{\circ}$, inciso XIV, da Constituição. A constitucionalização dessa proteção implica diferentes parâmetros para a liberdade de informação e o sigilo de fonte no Brasil - cujo sistema de justiça, igualmente aos demais países, inevitavelmente terá de lidar com desafios e conflitos gerados pela massificação da informação digital.

Há, portanto, questões controversas e problemáticas que até o momento passaram ao largo de obras brasileiras de direito constitucional. No âmbito da temática relativa aos direitos fundamentais, este trabalho pretende contribuir para esse debate.

\section{1.b - Pressupostos teóricos do trabalho: direitos fundamentais como princípios jurídicos}

Ainda nesta parte introdutória, é conveniente desenvolver em um tópico destacado as seguintes premissas de teoria constitucional, que serão adotadas ao longo do trabalho e utilizadas para desenvolver algumas das questões apresentadas nos próximos capítulos. Trata-se da teoria que reconhece no conjunto das normas jurídicas uma diferença estrutural entre regras e princípios, tal como formulada por Robert Alexy.

Obviamente, diversos pontos complexos e polêmicos emergem dessa proposição teórica. No entanto, o objetivo aqui é apenas pontuar seus principais 
aspectos, por meio de uma sucinta apresentação, para que sirvam de modo instrumental às análises sobre a oposição entre as abordagens institucional e funcional à liberdade de imprensa e à aplicação da regra constitucional de proteção ao sigilo de fonte.

Em síntese, a teoria formulada por Robert Alexy propõe que as normas jurídicas podem ter a estrutura de regras ou de princípios (distinção qualitativa) ${ }^{14}$. As regras jurídicas impõem direitos ou deveres definitivos, uma vez que os resultados jurídicos previstos por elas devem sempre incidir quando forem aplicáveis a um caso concreto - ou seja, quando sua hipótese de incidência for confirmada. As regras, portanto, são aplicadas por um esquema de subsunção. Se uma regra deixar de gerar efeitos em um determinado caso, isso significa, em geral, que ela é inválida e inaplicável aos demais casos análogos ${ }^{15}$. Como exemplos de regras jurídicas, podemos mencionar o inciso LVI do artigo $5^{\circ}$ da Constituição brasileira ("são inadmissíveis, no processo, as provas obtidas por meios ilícitos") ou o artigo 121 do Código Penal ("matar alguém: pena de reclusão de 6 a vinte anos").

Os princípios jurídicos, por sua vez, devem ser compreendidos como "mandamentos de otimização" - ou seja, normas jurídicas que determinam que algo deve ser realizado na máxima medida possível, a depender das circunstâncias fáticas e jurídicas existentes. Dessa definição decorre que os princípios jurídicos devem sempre ser considerados em uma análise jurídica de uma situação cujo tema os envolva. Os princípios, contudo, não enunciam direitos ou deveres definitivos: como sua estrutura normativa maximiza o âmbito de proteção e aplicação da norma, eles sempre enunciam um direito ou dever prima facie, ou seja, que somente será confirmado (ou tornado definitivo) após uma avaliação sobre as circunstâncias fáticas e jurídicas de um determinado cenário. Isso se explica exatamente porque diversos

\footnotetext{
${ }^{14}$ Robert Alexy, Teoria dos direitos fundamentais. São Paulo: Malheiros Editores, 2008.

${ }^{15}$ Robert Alexy, Teoria dos direitos fundamentais, pp. 92-93; Virgílio Afonso da Silva, Direitos Fundamentais: conteúdo essencial, restrições e eficácia. São Paulo: Malheiros, 2008, pp. 45-50. Há casos, porém, em que os efeitos de uma regra deixam de incidir em um caso concreto - não porque foram declaradas inválidas, mas porque foram superadas por um princípio jurídico. Sobre essa questão, ver: Rafael Scavone Bellem de Lima, Otimização de princípios, separação de poderes e segurança jurídica: o conflito entre princípio e regra. Dissertação de mestrado apresentada à Faculdade de Direito da Universidade de São Paulo em 2012.
} 
princípios jurídicos podem incidir em um determinado caso - cada qual determinando uma resolução diversa ou até mesmo contraditória ${ }^{16}$.

A consideração aos demais princípios jurídicos é, assim, uma circunstância que condiciona a própria aplicação de um determinado princípio. Os princípios, nesse sentido, costumam ser aplicados pelo método de sopesamento. Logo, se as consequências previstas por um princípio não preponderarem em um determinado caso, isso não significa que a norma seja inválida, nem que resultado diverso possa ocorrer em outro caso futuro. Os direitos fundamentais são, em regra, dispostos por normas jurídicas com estrutura de princípios.

O conceito de princípios como mandamentos de otimização está intimamente ligado à ideia de um suporte fático amplo para os direitos fundamentais. Com isso se quer rejeitar o conceito de que é possível definir previamente que uma determinada conduta ou situação esteja incluída ou excluída do âmbito de proteção a um direito fundamental.

Essa ideia pode ser apresentada de modo mais breve e direto a partir da seguinte ilustração: uma polêmica jurídica é causada porque um artista plástico utiliza aves vivas em cativeiro na instalação de uma obra sua, exposta em uma reconhecida galeria de arte. A polêmica consiste na discussão sobre se o artista tem ou não direito a utilizar aves vivas para sua manifestação intelectual. A adoção de um suporte fático restrito para a liberdade de expressão artística justifica dizer previamente que tal direito não compreende o uso de animais em obras artísticas. A negativa para a pretensão do artista, portanto, é rejeitada preliminarmente, com fundamento em alguma concepção a priorística sobre o que esse direito deve ou não permitir.

Ao contrário, a defesa de um suporte fático amplo para os direitos fundamentais contempla que a pretensão do artista é a priori protegida pela liberdade de manifestação artística - mas essa proteção preliminar deve ser analisada diante das demais condições fáticas e jurídicas do caso - como, por exemplo, os princípios que

\footnotetext{
${ }^{16}$ Robert Alexy, Teoria dos direitos fundamentais. São Paulo: Malheiros Editores, 2008, pp. 90 e seguintes; Virgílio Afonso da Silva, Direitos Fundamentais: conteúdo essencial, restrições e eficácia. São Paulo: Malheiros, 2008, pp. 47-50.
} 
fundamentam a proteção ambiental dos animais, bem como as regras jurídicas existentes sobre o tema ${ }^{17}$. Cria-se, assim, a necessidade de justificar uma eventual restrição ao reclamo do artista. E, se há uma ênfase no ônus argumentativo que motiva a restrição a um direito fundamental, evita-se um cenário no qual eles são restringidos de maneira imotivada ou obscura.

$\mathrm{Na}$ realidade, o principal mérito dessa proposição teórica - frise-se, apresentada de modo bastante resumido neste tópico - é rechaçar a ideia de que aquilo que é ou não protegido de modo definitivo por um direito fundamental pode ser delineado previamente. Ao conceber os princípios jurídicos como mandamentos de otimização, a teoria faz uma proposta bastante generosa de situações jurídicas potencialmente protegidas e joga luzes sobre a necessidade de apresentação de um ônus argumentativo para explicar porque eventualmente determinada proteção jurídica não deve prosperar em um determinado caso ${ }^{18}$.

Como já apontado, esses conceitos serão retomados algumas vezes ao longo do trabalho, em caráter instrumental para análises jurídicas que serão suscitadas. Feita esta apresentação inicial, passo ao tema da pesquisa.

\footnotetext{
17 “(...) toda ação, estado ou posição jurídica que tenha alguma característica que, isoladamente considerada, faça parte do 'âmbito temático' de um determinado direito fundamental deve ser considerada como abrangida por seu âmbito de proteção, independentemente da consideração de outras variáveis". Virgílio Afonso da Silva, Direitos Fundamentais: conteúdo essencial, restrições e eficácia, pp. 47-50.

${ }^{18}$ Virgílio Afonso da Silva, Direitos Fundamentais: conteúdo essencial, restrições e eficácia, pp. 123125 .
} 


\section{Capítulo 2 - Uma breve contextualização histórica}

Ao longo deste trabalho, um tema recorrente será o entrelaçamento, sob diferentes enfoques e propostas, das liberdades de imprensa e de expressão. De fato, em suas origens e evoluções históricas, as compreensões sobre esses dois direitos fundamentais se aproximam e por vezes se confundem ${ }^{19}$. Embora isso possa parecer bastante natural, torna-se desejável compreender algumas razões para essa colocação.

Para além de um breve relato cronológico, este capítulo busca relatar as principais mudanças de contextos e concepções que condicionam o atual estágio da discussão sobre o tema desta pesquisa. Condensado em uma apresentação inicial, espera-se que sirva como pano de fundo para as discussões que serão apresentadas a seguir - a apresentação da jurisprudência constitucional norte-americana, as abordagens institucional e funcional à liberdade de imprensa e uma proposta de contribuição para a interpretação constitucional brasileira.

Essa reconstrução histórica será apresentada em quatro movimentos sucessivos: "liberdade de impressão", "liberdade de expressão", “jornalismo profissional" e "informações e expressões em rede".

\section{2.a - Liberdade de impressão}

Durante os séculos XVIII e XIX, quando foi incorporada pelos principais textos do constitucionalismo moderno, a liberdade de imprensa era compreendida como a liberdade de imprimir qualquer texto sem a necessidade de licença prévia por parte do governo - fosse um jornal periódico ou um livro com aspirações filosóficas e políticas, em uma época de revoluções. Ou seja: liberdade de imprensa referia-se à liberdade de uso da tecnologia disseminada por Gutenberg.

\footnotetext{
19 “Até o último quarto do século XVIII, liberdade de expressão referia-se não a um direito civil, mas essencialmente a um direito parlamentar: a imunidade do legislador quanto a uma punição por algo dito em sua atribuição oficial durante a sessão legislativa. $O$ direito pessoal do cidadão à liberdade de expressão desenvolveu-se a partir da liberdade de imprensa e da liberdade de religião - a liberdade de falar livremente sobre governo e religião desenvolveram-se mais tarde" - Leonard W. Levy, Emergence of a Free Press. Chicago: Ivan R. Dee, 2004, p. 3.
} 
À época da invenção de Gutemberg, ainda no século XV, era natural que o ato de imprimir fosse tomado como uma prerrogativa exclusiva da coroa de qualquer regime absolutista, a quem caberia monopolizá-la ou autorizá-la a terceiros, se de acordo com os textos a serem divulgados.

A Inglaterra foi o primeiro país a superar a necessidade de licença prévia estatal. O rei Henrique VIII havia estabelecido a licença prévia para escritos de todos os tipos - inicialmente baseado em um sistema de censura contra manuscritos considerados hereges pela Igreja, com aprovação do Parlamento. Todos os manuscritos deveriam ser aprovados por oficiais reais antes de sua publicação e a falta dessa licença prévia significava que a publicação seria considerada criminosa. A despeito de algumas mudanças pontuais ao longo dos anos, esse sistema foi mantido pelo Parlamento durante o período da Restauração, até ser finalmente abolido em $1694^{20}$.

Na tradição jurídica britânica, nenhum autor resumiu essa ideia melhor do que William Blackstone - sua obra "Comentários às leis da Inglaterra", publicada originalmente entre 1765 e 1769 , é considerada o primeiro tratado sobre a common law inglesa na era moderna. Não apenas teve influência predominante e duradora em sua terra natal, mas era considerada a principal fonte interpretativa sobre a common law pelas cortes da colônia americana. Para Blackstone, essencialmente, liberdade de imprensa significava "freedom from prior restraint". Ou seja: a liberdade de se imprimir textos sem a necessidade de autorização prévia ${ }^{21}$.

O mais importante sobre essa definição, contudo, é o que estava excluído do seu âmbito de proteção: a common law inglesa criminalizava qualquer crítica contra a coroa, por meio de suas libel laws (leis de sedição, em tradução livre). Predominava a noção de que palavras ou ideias, se prejudiciais à ordem pública ou à moral e reputação dos governantes, deveriam ser punidas. Essa concepção garantia o direito de publicar, mas não afastava a possibilidade de punição criminal por afronta às autoridades constituídas.

\footnotetext{
${ }^{20}$ A esse respeito: Leonard W. Levy, Emergence of a Free Press, p. 6.

${ }^{21}$ William Blackstone, Commentaries on the Laws of England. Charles River Editors (versão digital), livro IV, capítulo XI.
} 
Para Blackstone, "nas situações em que difamações blasfemas, imorais, traiçoeiras, cismáticas, sediciosas ou escandalosas são punidas pela lei inglesa, a liberdade de imprensa, entendida corretamente, não é de forma alguma infringida ou violada. A liberdade de imprensa é de fato essencial para um estado livre; mas isso consiste em não estabelecer nenhuma restrição prévia a publicações, e não na liberdade de censura para material criminoso quando publicado. Todo homem livre tem sem dúvidas o direito de levar ao público os sentimentos que quiser: proibir isso é destruir a liberdade de imprensa; mas se ele publicar o que é impróprio, perverso, ou ilegal, ele deve encarar as consequências de sua própria temeridade"22.

Essa influente e duradoura doutrina jurídica - como não poderia deixar de ser - refletia um pensamento político mais amplo e há muito tempo consolidado. Radical para sua época, o notório panfleto "Aeropagitica: discurso pela liberdade de imprensa ao Parlamento da Inglaterra" foi publicado e distribuído ilegalmente em 1644 por John Milton - tratava-se de um libelo contra o ato do Parlamento que reinstituiu o sistema de licença prévia no ano anterior ${ }^{23}$. Até hoje, mais de três séculos depois de escrito, é reverenciado como um clássico do liberalismo político e da defesa da pluralidade de ideias - e dotado de trechos célebres que representam esse ideário ${ }^{24}$.

Apesar de estar à frente de seu tempo, mesmo Milton - ressonado por Blackstone, cerca de um século depois - advogava que a liberdade de imprimir não implicava a tolerância posterior de publicações impróprias: "não nego que seja da maior importância para a Igreja e a Commonwealth manter um olhar vigilante tanto sobre o comportamento dos livros quanto dos homens. E, por conseguinte, confinálos, encarcerá-los e submetê-los à mais rigorosa justiça como malfeitores. Porque os

\footnotetext{
${ }^{22}$ William Blackstone, Commentaries on the Laws of England, livro IV, capítulo XI.

${ }^{23} \mathrm{O}$ sistema de licença prévia havia sido revogado em 1641 por ter sido considerado "illegal e tirânico". Segundo consta, foi restabelecido dois anos depois após Milton publicar uma defesa da legalização do divórcio após um casamento frustrado - "A doutrina e disciplina do divórcio" -, o que gerou fortes reações dos parlamentares. Felipe Fortuna, "John Milton e a Liberdade de Imprensa", in John Milton, Aeropagítica: discurso pela liberdade de imprensa ao Parlamento da Inglaterra. Rio de Janeiro: Topbooks, 1999, pp. 11-12.

${ }^{24}$ John Milton, Aeropagítica: discurso pela liberdade de imprensa ao Parlamento da Inglaterra: "Daime a liberdade para saber, para falar e para discutir livremente, de acordo com a consciência, acima de todas as liberdades" (p. 169); "Que a verdade e a impostura se digladiem. Quem jamais ouviu dizer que a verdade perdesse num confronto em campo aberto? Sua refutação é a melhor e mais eficaz das proibições" (p. 173).
} 
livros não são absolutamente coisas mortas; contêm uma espécie de vida em potência, tão prolífica quanto a da alma que as engendrou (...). E que, uma vez semeados aqui e ali, podem dar nascimento a homens armados"25.

No Brasil, a proibição total de produção de impressos perdurou até 1808 - ano em que a corte portuguesa desembarcou no país, em fuga da metrópole motivada pelas guerras napoleônicas ${ }^{26}$. A chegada de d. João VI motivou inúmeros avanços econômicos e sociais à principal colônia portuguesa - entre eles, a tecnologia de impressão. O jornal oficial Gazeta do Rio de Janeiro passou a publicar os atos da coroa e elogios à família real ${ }^{27}$.

O primeiro jornal brasileiro, contudo, foi o Correio Braziliense - impresso na Inglaterra pelo brasileiro Hipólito da Costa exatamente para fugir da censura prévia imposta à época. O Correio Braziliense circulou entre 1808 e 1822 (ano da independência), advogando os ideais do liberalismo e as vantagens de um sistema constitucional de governo ${ }^{28}$.

O Brasil "alcança" a concepção de Blackstone de liberdade de imprensa apenas em 1821, quando d. João VI promove a abolição da censura prévia, estendendo à colônia, após pressões de liberais brasileiros, uma medida que já vigorava em Portugal desde a Revolução Liberal do Porto do ano anterior ${ }^{29}$.

\footnotetext{
${ }^{25}$ John Milton, Aeropagitica: discurso pela liberdade de imprensa ao Parlamento da Inglaterra, p. 61. Outros trechos igualmente reforçam essa preocupação de Milton: "quanto à regulamentação da imprensa, que ninguém se arrogue a honra de vos dar conselhos. Nada melhor que a vossa Ordenação publicada antes desta última, segundo a qual nenhum livro será impresso, a não ser que o nome do impressor e o nome do autor, ou pelo menos, o do impressor esteja registrado. Para os livros que vêm a lume de outro modo, caso sejam considerados daninhos e caluniosos, o fogo e o carrasco serão o remédio mais oportuno e eficaz oferecidos à ação preventiva das autoridades" (p. 185); "até então os livros sempre foram admitidos livremente no mundo como qualquer outro nascimento. Os frutos do cérebro não eram mais sufocados do que os do útero (...). Produzisse ele, porém, um monstro, e todos achariam justo que fosse queimado ou lançado ao mar. Mas nunca se ouvira dizer que um livro, em pior situação do que uma alma pecadora, devesse ficar postado diante de um júri antes de vir ao mundo (...)." (p. 79).

26 "O Brasil colonial, ao contrário de alguns de seus vizinhos na América Latina, não tinha universidades. Era também um dos únicos países do mundo, excetuados os da África e da Ásia, que não produzia palavra impressa. Até 1808 , data da chegada de d. João VI, as letras impressas eram proibidas por aqui. As poucas tentativas de se estabelecerem tipografias esbarraram na intransigência das autoridades portuguesas" - Isabel Lustosa, O nascimento da imprensa brasileira. Rio de Janeiro: Jorge Zahar Editor, 2003, p. 7.

${ }^{27}$ Oscar Pilagallo, História da imprensa paulista. São Paulo: Três Estrelas, 2012, p. 17.

${ }^{28}$ Isabel Lustosa, O nascimento da imprensa brasileira, p. 8.

${ }^{29}$ Oscar Pilagallo, História da imprensa paulista, p. 17.
} 
Ao longo do final do século XVIII e do século XIX entretanto, o exercício da liberdade de imprensa iria incorporar uma nova dimensão substancial relacionada às liberdades políticas democráticas, que muito se aproxima do que normalmente se considera como liberdade de expressão. Esse movimento pode ser bem observado no pioneiro exemplo norte-americano.

\section{2.b - Liberdade de expressão}

Nos Estados Unidos, os jornais da época pré-revolucionária e de independência caracterizavam-se por textos claramente partidários, críticos ou apoiadores de governos e facções políticas.

Embora inicialmente predominante, a concepção jurídica de Blackstone sobre a liberdade de imprensa seria cada vez menos adequada à realidade de uma república construída sobre governos representativos, em contraste com uma monarquia calcada na relação entre súditos e soberanos. Nesse novo sistema político, criticar as autoridades livremente não poderia mais ser considerado um ato de sedição, mas sim um direito.

Historicamente, o principal debate histórico que sucedeu a promulgação da Constituição americana e de sua Primeira Emenda - e que teve importância definitiva para os valores atrelados à retórica da liberdade de imprensa e de expressão - dizia respeito à possibilidade de se processar criminalmente alguém por opiniões críticas feitas contra autoridades.

Esse debate desenvolveu-se principalmente pela publicação do Sedition Act de 1798, que criminalizava, entre outras condutas, "escritas, impressões ou publicações" com imputações "falsas, escandalosas ou maliciosas" contra o governo norteamericano, o Congresso Nacional ou o presidente.

A lei foi aprovada durante a presidência de John Adams (federalista). Não era previsto o ato de sedição contra o cargo de vice-presidente, então ocupado por Thomas Jefferson (republicano). A lei tinha validade estipulada previamente até 3 de 
março de 1801, véspera do término do mandato de Adams. Após assumir a presidência, Jefferson, que sempre sustentou a inconstitucionalidade da lei em virtude da liberdade de expressão prevista pela Primeira Emenda, concedeu perdão presidencial a todos os condenados, com direito a indenizações pelo governo federal. A lei foi um dos tópicos mais abordados durante as eleições de 1800, quando os federalistas foram em grande medida derrotados pelos republicanos ${ }^{30}$.

As críticas contra essa lei consideravam-na inconstitucional com fundamento nas liberdades de imprensa e de expressão. Não se trata de mudança trivial. A concepção "blackstoniana" de liberdade de imprensa, voltada exclusivamente à liberdade de disseminação de escritos por meio da tecnologia de impressão, começa a adquirir em debates judiciais e públicos uma dimensão substancial, relacionada à prerrogativa - defendida como inerente à democracia, ao autogoverno e à cidadania de liberdade de crítica contra autoridades públicas. Nessa época ganha corpo a ideia de imprensa como um quarto-poder, cuja razão de ser é fiscalizar ("watchdog") os três poderes oficiais.

Leonard Levy avalia como "libertária" a corrente de pensamento que promoveu o abandono da concepção de Blackstone sobre a liberdade de imprensa e a incorporação a seu significado de um amplo direito de crítica decorrente do autogoverno democrático - à época, não custa lembrar, uma exceção à forma de governo predominante no ocidente. Na prática, isso significou a derrubada da concepção de que era possível "criminalizar palavras ou críticas contra o governo", um significativo distanciamento da tradição inglesa sobre o tema ${ }^{31}$.

Essa mudança de concepção jurídica acompanhava o cenário da imprensa daquele país: os jornais eram aguerridos, panfletários e opinativos, e tiveram

\footnotetext{
${ }^{30}$ Ela nunca chegou a ser analisada pela Suprema Corte americana, que reconheceu a si a prerrogativa de avaliar a constitucionalidade de leis apenas em 1803, no julgamento de Marbury v. Madison. O histórico do Sedition Act, entretanto, foi um dos argumentos utilizados pelo juiz Brennan em seu voto no caso New York Times Co. v. Sullivan (1964), que será analisado no capítulo 3 (item 3.b).

${ }^{31}$ Levy busca argumentar que historicamente houve uma evolução política pioneira da sociedade americana para uma "teoria libertária" de liberdade de imprensa. Ele busca desmistificar a ideia de que os "founding fathers" sempre tiveram uma percepção efetivamente democrática sobre esse direito para ele, à época da promulgação da Constituição, prevalecia o conceito de Blackstone, consagrado pela common law, entre legisladores e juristas - uma interpretação que se tornou anacrônica apenas anos após a instalação da república - Leonard W. Levy, Emergence of a Free Press, p. 349.
} 
importância fundamental para o processo de independência e de disputas políticas internas. Essas características não eram fruto do acaso. Até aproximadamente o final do século XIX, não existia tecnologia capaz de disseminar informações a um grande público em um curto espaço de tempo. Não havia repórteres profissionais. Os jornais eram essencialmente locais e partidarizados; seu conteúdo era em regra formado por editoriais opinativos e cartas de leitores, cujos textos eram voltados a círculos sociais e comunidades restritas.

De um modo geral, esse quadro de imprensa engajada e militante do século XIX também pôde ser observado no Brasil. Além do proselitismo liberal do Correio Braziliense, merecem menção os panfletos e jornais Despertador Braziliense, Malagueta e Revérbero Constitucional Fluminense, que tiveram papel proeminente para sublevação de D. Pedro I contra as cortes portuguesas, culminando no "Dia do Fico". Após a decretação da independência, os impressos passaram a refletir as divergências sobre os rumos que deveriam ser tomados pelo país - dividindo-se, em especial, entre defensores do regime republicano e da monarquia constitucional. A oposição a D. Pedro I feita principalmente por meio de artigos em jornais da época levou o monarca a dissolver a primeira assembleia constituinte brasileira, em $1823^{32}$. Para Isabel Lustosa, "esse curto período de nossa história”, na qual o Brasil viveu um período de intensas e profundas transformações, "foi o contexto em que política e imprensa se confundiram da maneira mais radical",33.

Ao longo do século seguinte, esse perfil de imprensa seria drasticamente alterado.

\section{2.c - A imprensa profissional}

\footnotetext{
${ }^{32}$ Isabel Lustosa, $O$ nascimento da imprensa brasileira, pp. 24-52.

${ }^{33}$ Isabel Lustosa, O nascimento da imprensa brasileira, pp. 58-59. Também no Brasil uma atuação política engajada da imprensa local iria motivar tensões com os poderes constituídos. Oscar Pilagallo narra que uma carta de lei de D. Pedro I de 1823 "apesar de defender a liberdade de imprensa como um dos firmes sustentáculos dos governos constitucionais, previa punições por abusos. Por exemplo: a negação de dogmas da religião católica era punida com um ano de prisão; zombar de Deus, seis meses de detenção; incitar rebeliões, dez anos de degredo; atacar a forma de governo monárquico constitucional, cinco anos de degredo; caluniar funcionário público, seis meses de prisão" - História da imprensa paulista, p. 18. Essa regulamentação sobre os "abusos da imprensa" foi feita após episódios de crises e de processos criminais instaurados contra jornalistas, ainda sob aplicação de antigas leis portuguesas (Isabel Lustosa, O nascimento da imprensa brasileira, p. 31).
} 
Na virada do século XX, o processo de produção da imprensa beneficiou-se de um quadro de significativas alterações tecnológicas: avanços de técnicas de impressão, desenvolvimento de infraestrutura viária de distribuição, além de uma popularização cada vez mais veloz de telégrafos e telefones para a apuração de notícias em locais distantes, entre outros fatores, permitiram que os jornais passassem a mirar um mercado de leitores cada vez mais amplo - e de massas.

Consolida-se a era industrial de produção de notícias. Se os custos de produção mantinham os empreendimentos restritos a seletos grupos, a expansão do alcance de leitores criava as condições para o modelo que sustentaria esse negócio pelas décadas seguintes: a publicidade pagaria boa parte das contas, e o preço do produto poderia ser acessível.

A "vanguarda" desse movimento é a penny press de Nova York, inaugurada ainda na década de 1830. Em setembro de 1833, Benjamin Day lançou seu novo jornal - The Sun, que se ocupava principalmente dos crimes mais comoventes da época - ao preço de um centavo por edição, seis vezes mais barato que a maior parte da concorrência. A estratégica funcionou: em dois anos, o Sun vendia 15 mil exemplares diários, cerca de quatro vezes mais do que o jornal outrora mais popular da época, o também nova-iorquino Courier and Enquirer ${ }^{34}$. A experiência de Nova York - já uma metrópole à época - foi precoce, mas anunciou um modelo que iria marcar o século $\mathrm{XX}^{35}$.

A alta circulação atraiu anunciantes e possibilitou a tomada do mercado com um produto a baixo preço. "Era um ótimo negócio para todos os envolvidos: os leitores recebiam notícias a preço baixo, anunciantes podiam alcançar um público

\footnotetext{
34 "Special report: The news industry", The Economist, reportagem publicada na edição de 09.07.2011. David Mindich aponta ainda que os então tradicionais jornais de "seis pennies" eram ligados a partidos politicos, em continuação ao perfil da imprensa desde a época da Independência, e cobriam as disputas políticas e os interesses comerciais de seus respectivos grupos de leitores. Os novos jornais de "um penny" desconectaram-se dessa tradição e passaram a cobrir assuntos de interese geral - em especial, crimes - David Mindich, Just the facts: how 'objectivity' came to define American journalism. New York: New York University Press, 1998, p. 17.

${ }^{35}$ Nesse sentido: Paul Horwitz, "Or Of The Blog", Nexus 11 (2006), p. 10; David S. Allen, "The Institutional Press and Professionalization: Defining the Press Clause in Journalist's Privilege", The Free Speech Yearbook 34 (1997): 49-62.
} 
amplo e os jornais podiam arcar com repórteres profissionais ao invés de dependerem de amadores" 36 .

Os jornais passam a ser produzidos no âmbito de empresas inseridas em uma lógica industrial, com jornalistas remunerados e profissionais, responsáveis por disseminar as informações ao grande público. "Pela primeira vez, a distribuição vertical de notícias, de uma elite especializada para o público, teve uma vantagem decisiva sobre a distribuição horizontal entre os cidadãos. Essa tendência se acelerou com o advento do rádio e da televisão no século vinte" ${ }^{37}$.

Não por acaso, é nesse contexto que se consolida a pretensão de oferecer à sociedade relatos técnicos e objetivos - o ideal de "objetividade jornalística": "quando se é o único jornal na cidade, não se pode arriscar irritar os liberais por ser muito conservador - e vice-versa",38. Quanto menos os jornais alienassem o público por suas preferências ideológicas, mais os anunciantes poderiam direcionar suas campanhas a todos. A influência política de um jornal, por outro lado, também poderia ser medida pela sua posição no mercado.

Para Carlos Eduardo Lins e Silva, "o pluralismo e o apartidarismo são necessários não porque eles representam uma objetividade eticamente desejável, nem porque eles signifiquem que o jornal é capaz de representar o real sem deformações, mas apenas porque o público que consome o jornal é composto por pessoas com diferentes visões de mundo e, como o jornal não pode prescindir de nenhum grupo significativo de seus leitores, deve representar cada um deles no noticiário e não discriminar nenhum". O comentário do jornalista é feito em análise ao projeto editorial implementado pelo jornal Folha de S. Paulo na década de 1980, do qual participou, que buscava prezar pelo pluralismo de ideias e pelo apartidarismo ${ }^{39}$.

\footnotetext{
36 "Special report: The news industry", The Economist, edição de 09.07.2011.

37 "Special report: The news industry", The Economist, edição de 09.07.2011.

38 "Special report: The news industry", The Economist, edição de 09.07.2011.

${ }^{39}$ Carlos Eduardo Lins da Silva, Mil dias: seis mil dias depois. São Paulo: Publifolha, 2005, p. 130. A questão da objetividade jornalística será retomada no capítulo 4 (item 4.e.iii).
} 
Novamente, a mudança é significativa. A liberdade de imprensa passa a ser conectada não a um direito de crítica ou de opinião, mas à atividade específica de disseminar informações corretas e objetivas sobre temas de interesse público.

A capacidade dos "membros da imprensa" e dos veículos jornalísticos de fornecerem à sociedade esse "serviço público", mediante tecnologia e know-how específicos, é que permite que seus profissionais justifiquem para si prerrogativas próprias - como o sigilo de fonte - que decorreriam do interesse social subjacente à colheita e divulgação de informações.

Nos Estados Unidos, a judicialização de demandas por prerrogativas próprias de jornalistas atinge seu ápice nas décadas de 1960 e 1970. Trata-se da época de pioneira relevância social do jornalismo investigativo naquele país, simbolizado pelos casos Watergate e Pentagon Papers ${ }^{40}$.

Nesse contexto, a constitucionalização da proteção ao sigilo de fonte ocorrida no Brasil em 1988 situa-se cronologicamente em um período de auge da afirmação de prerrogativas da imprensa profissional, poucos anos antes da massificação da liberdade de informação promovida pela internet.

\section{2.d - Informações e expressões em rede}

O cenário atual que motiva este trabalho já foi exposto, em linhas gerais, na apresentação de seu tema. De qualquer modo, cabem aqui algumas considerações que, por um lado, complementam esta breve contextualização histórica e, por outro, buscam afastar qualquer tom de deslumbramento sobre o impacto da internet para a liberdade de informação.

De um modo geral, a ideia bastante difundida de que a internet necessariamente implica uma ampliação de liberdades democráticas é alvo de críticas contundentes. A rede não está imune às relações de poder ou a contextos geopolíticos. E, se por um lado ela possibilita maior articulação entre as pessoas e seus pontos de

\footnotetext{
${ }^{40}$ Os casos Watergate e Pentagon Papers são apresentados no início do capítulo 3.
} 
vista, ela também pode aperfeiçoar o monitoramento de indivíduos e os mecanismos de repressão de regimes autoritários ${ }^{41}$.

Jornalistas profissionais também chamam a atenção para a rápida proliferação de boatos com graves consequências ${ }^{42}$, para o compartilhamento gratuito de textos publicados por veículos pagos ${ }^{43}$ e pela concorrência que, de um modo geral, coloca em xeque o modelo que sustentou ao longo do último século o jornalismo profissional e especializado, idealmente capaz produzir custosas reportagens investigativas.

Para Otávio Frias Filho, publisher da Folha de S. Paulo, “(...) muito desse novo jornalismo tem qualidade discutível, quando não é produto de mera pirataria. Os blogs e o jornalismo cidadão parecem oportunidades promissoras, mas quase sempre seu alcance fica limitado, seja em termos de recursos ou abrangência, seja porque expressam visões demasiado particulares e engajadas (...). Durante décadas, o jornalismo clássico, dito de qualidade - que cultiva compromissos com a exatidão do que publica, com a relevância coletiva dos termos que aborda, com a manutenção do debate público - foi sustentado por um modelo econômico hoje em risco"44.

$\mathrm{O}$ aspecto mais interessante sobre o impacto da internet para as liberdades de informação e de expressão, contudo, foi apontado em reportagem da revista britânica The Economist. Segundo o texto, "há uma grande ironia histórica no centro das transformações atuais das notícias". A publicação argumenta que a internet - e os

\footnotetext{
${ }^{41}$ A esse respeito: Evgeny Morozov, The Net Delusion: the dark side of internet freedom. New York: Public Affairs, 2011. O autor critica o que denomina de "utopia cibernética", minimizando o "potencial revolucionário" de mobilizações por redes sociais e enfatizando a inserção da internet em contextos políticos de relações internacionais e de conjunturas internas. Outras discussões igualmente importantes se colocam com relação à internet: a regulação do trâmite de dados por meio dos servidores, com eventual facilitação ou restrição a alguns canais ou serviços; o impacto das restrições de políticas de uso de empresas (como Google ou Apple) sobre a liberdade de expressão dos usuários; políticas de privacidade dos dados dos usuários, etc.

42 "Um post de um internauta no site iReport, área de jornalismo-cidadão da CNN, no qual afirmava que Steve Jobs, presidente da Apple, tinha morrido de um ataque do coração derrubou em 5,4\% as ações e obrigou a empresa a desmentir publicamente a informação. (...) o boato chamou a atenção para o risco de as redes sociais serem utilizadas com o objetivo de manipular e de ganhar dinheiro no mercado". "Mídia social dissemina boatos e desafia mercados", Folha de S. Paulo, reportagem publicada em 20.06.2011.

${ }^{43}$ Bill Keller, "All the Aggregation That's Fit to Aggregate", New York Times Magazine, artigo publicado em 10.03.2011 <disponível em http://www.nytimes.com/2011/03/13/magazine/mag-13ledet.html>.

${ }^{44}$ Octávio Frias Filho, "7 vidas do jornalismo", Folha de S. Paulo, artigo publicado em 23.05.2011.
} 
hábitos das redes sociais, em particular - têm aproximado o exercício atual do jornalismo à sua realidade pré-industrial ${ }^{45}$.

A internet teria desestabilizado o modelo vertical do século XX e permitido que o aspecto social da mídia ressurgisse. Câmeras, blogs, Facebook e Twitter podem parecer inteiramente novos, mas eles "ecoam as formas em que as pessoas costumavam colher, compartilhar e trocar informações no passado". Segundo a publicação, as notícias têm se tornado mais diversificadas na medida em que as ferramentas se tornam mais disponíveis. Mas, ao mesmo tempo, "notícias têm se tornado mais opinativas, polarizadas e partidárias, como costumava ser nos tumultuados dias do panfletarismo". A avaliação é de que "a maior mudança é que o jornalismo não é mais uma prerrogativa exclusiva de jornalistas. Pessoas comuns têm tido um papel mais ativo no sistema de notícias, em conjunto com empresas de tecnologia, iniciantes e grupos sem interesse lucrativo" ${ }^{46}$.

\section{2.e - Considerações finais do capítulo}

A apresentação de sucessivos movimentos históricos buscou não apenas enfatizar os principais pontos da evolução da imprensa nos últimos séculos, mas também denotar como as compreensões relativas a essa liberdade são contingentes e relativas em face às condições da época.

Este trabalho não pretende analisar ou fazer prognósticos sobre o impacto de novas tecnologias na qualidade do jornalismo ou nos eventuais modelos econômicos que sustentarão sua produção. Essas circunstâncias dependerão de inúmeros fatores e nenhum deles parece ser jurídico.

Mas ao se constatar essa ruptura da estrutura de um antigo modelo vertical e concentrado de liberdade de imprensa, torna-se conveniente problematizar se, à luz de liberdades constitucionais, pode o Estado diferenciar os cidadãos em geral de jornalistas profissionais - conferindo ou não a estes últimos uma liberdade de informação qualificada.

\footnotetext{
45 "Special report: The news industry", The Economist, edição de 09.07.2011.

46 "Special report: The news industry", The Economist, edição de 09.07.2011.
} 


\section{Capítulo 3 - A liberdade de imprensa no direito constitucional norte- americano: o papel da press clause para sua Suprema Corte}

No capítulo anterior, apontei que ao longo do século XX - à luz de uma série de novas condições tecnológicas e de um novo modelo de negócio - a liberdade de imprensa passou a ser compreendida como a liberdade/capacidade de disseminar informações corretas e objetivas sobre temas de interesse público.

Os membros da imprensa, ao advogarem técnicas e know how específicos, passaram a se apresentar como profissionais de uma atividade especializada. Esse movimento é acompanhado de uma demanda crescente por prerrogativas próprias como o sigilo de fonte - que seriam justificadas pelo benefício gerado à sociedade por um robusto fluxo de informações.

Como apontado anteriormente, nos Estados Unidos, a judicialização de demandas por prerrogativas próprias para a imprensa atinge seu ápice nas décadas de 1960 e 1970 - época de pioneira relevância do jornalismo investigativo naquele país, simbolizado pelos casos Watergate $^{47}$ e Pentagon Papers ${ }^{48}$. Conforme será demonstrado, entretanto, a Suprema Corte americana nunca admitiu uma diferenciação entre imprensa e cidadãos comuns.

\footnotetext{
${ }^{47}$ Escândalo político que levou à renúncia do presidente Richard Nixon, em 1974, após ficar comprovado que ele e sua equipe tentaram acobertar as investigações sobre uma invasão ao escritório do Partido Democrata em Washington, dois anos antes. As reportagens publicadas pelo jornal Washigton Post, contendo importantes informações sob sigilo de fonte, foram determinantes para pressionar as autoridades policiais a investigarem os integrantes do governo federal e para que o Senado criasse uma comissão investigativa a respeito.

${ }^{48}$ Em 1971, o jornal New York Times publicou reportagem sobre um relatório confidencial feito pelo Departamento de Defesa a respeito do envolvimento político e militar dos Estados Unidos no Vietnã, entre os anos de 1945 e 1967. O texto buscava demonstrar contradições entre as posições públicas do governo federal de Lyndon Johnson e suas reais intenções e decisões, em um contexto de crescentes críticas públicas à guerra. Em um primeiro momento, o governo obteve uma decisão judicial impedindo a continuação da cobertura, sob o argumento de que ela colocava em risco a segurança nacional. Em junho daquele ano, a Suprema Corte decidiu pela constitucionalidade da publicação, argumentando - com bastante ênfase aos limites concretos daquele caso - que o governo falhou em demonstrar que havia real risco à segurança nacional capaz de justificar uma censura prévia - New York Times Co. v. United States (1971). Para um relato detalhado sobre o caso Pentagon Papers, ver: Floyd Abrams, Speaking Freely: Trials of the First Amendment. New York: Penguin Books, 2005, pp.1-61.
} 
Neste capítulo, será feita uma apresentação da jurisprudência da Suprema Corte norte-americana - que consistirá em uma análise sobre como uma das cortes mais influentes do mundo relegou a previsão constitucional da "liberdade de imprensa" ("press clause") a uma irrelevância - ou redundância - posta ao lado da "liberdade de expressão" ("speech clause") 49

\section{3.a - A imprensa "auto-evidente" das primeiras décadas do século XX}

Na primeira metade do século XX, a Suprema Corte costumava fundamentar importantes decisões através de referências diretas e exclusivas à liberdade de imprensa ("press clause").

Como exemplos, podem ser mencionados os seguintes $\operatorname{casos}^{50}$ : a) Grosjean $v$. Am. Press Co. (1936), no qual a corte julgou inconstitucional por ofensa à liberdade de imprensa a instituição de um tributo pelo estado da Louisiana destinado apenas aos jornais com tiragem superior a 20 mil exemplares por semana, considerando a imposição da taxa uma forma branda de licença prévia, que buscava silenciar às críticas ao governo; b) Lovell v. City of Griffin (1938), no qual a corte explicitou a desnecessidade de uma testemunha de Jeová obter autorização do município conforme previsto por uma lei local - para distribuir panfletos religiosos em sua cidade e, ainda; c) Mills v. Alabama (1966), no qual a corte reconheceu o direito de um editor de um jornal local publicar um editorial exortando os eleitores a votarem em determinado candidato, no dia da eleição, a despeito de uma vedação prevista pela legislação do estado do Alabama.

\footnotetext{
49 "A liberdade de imprensa ("Press Clause") hoje nada mais é do que uma força invisível no direito constitucional: influencia nossa interpretação da liberdade de expressão ("Speech Clause"), mas não gera nenhum efeito independente. Isso não foi sempre o caso. Nos primeiros anos da jurisprudência da Primeira Emenda, a Suprema Corte com freqüência se utilizava expressamente da liberdade de imprensa como fonte de direitos para a imprensa. Mas pelos últimos 30 ou 40 anos, a Corte tem se recusado a dar à liberdade de imprensa qualquer significado diferente daquela da liberdade de expressão. Quando confrontada com reclamos baseados na liberdade de imprensa, a Corte normalmente utiliza a liberdade de expressão de forma ampla o suficiente para proteger o direito em questão, e quando isso não é possível - quando os direitos reclamados não podem ser ampliados a todos - a corte os nega"- David Anderson, "Freedom Of The Press in Wartime", University of Colorado Law Review 77 (2006), p. 66. No mesmo sentido: Scott Gant, We're all Journalists Now, p. 55; Frederick Schauer, "Towards an Institutional First Amendment", Minnesota Law Review 89 (2005), p. 2.

${ }^{50}$ Todos apresentados por David Anderson: "Freedom Of Press in Wartime", p. 69.
} 
Para Anderson, "em retrospecto, esses primeiros casos parecem naturais e ingênuos. Os requerentes eram claramente imprensa por qualquer definição, então porque seus pedidos não deveriam ser analisados sob a liberdade de imprensa? (...) Ao mesmo tempo, parece que o potencial problema de decidir quem deve ser considerado imprensa nunca incomodou a Corte naqueles casos. As decisões simplesmente presumiam que os litigantes eram imprensa e não levavam em conta como essa identificação poderia ser feita se isso não fosse óbvio" 51 .

A relevância jurídica da "press clause", entretanto, começaria a diminuir na retórica da Suprema Corte. Em casos nos quais as decisões iriam beneficiar conjuntamente jornalistas e cidadãos em geral - New York Times Co. v. Sullivan (1964) é seu principal exemplo e será analisado no próximo tópico - a corte promoveria os fundamentos de "freedom of speech and press" ou "freedom of expression". Eventualmente, a corte minimizaria as referências à "liberdade de imprensa" mesmo em casos que envolviam exclusivamente jornalistas profissionais as decisões favoráveis seriam concedidas com fundamento em ambas "speech and press clauses" ${ }^{\prime 2}$.

Ao final, esse processo de perda de relevância da "press clause" iria se firmar com a correspondente negativa da corte, por repetidas vezes, de reconhecer quaisquer prerrogativas especiais à imprensa em comparação aos cidadãos em geral.

Para demonstrar esse cenário, quatro casos merecerão especial atenção: New York Times Co. v. Sullivan (1964), Branzburg v. Hayes (1972), Landmark Communications v. Virginia (1978) e Bartnicki v. Vopper (2001).

\section{3.b - New York Times Co. v. Sullivan (1964)}

O caso New York Times Co. v. Sullivan é comumente considerado um marco de proteção constitucional à liberdade de imprensa ${ }^{53}$. A decisão derrubou à época uma

\footnotetext{
${ }^{51}$ David Anderson, "Freedom Of Press in Wartime", pp. 69-70.

52 David Anderson, "Freedom Of Press in Wartime", pp. 69-70.

53 "Nenhuma decisão da Suprema Corte neste século é mais importante para nossa noção sobre o que significa liberdade de imprensa. Foi uma daquelas raras decisões que forneceram um quadro conceitual e um idioma para sua época" - Lee C. Bollinger, Images of a Free Press. Chicago: University of
} 
condenação por difamação que implicava pesada condenação financeira contra o New York Times e, em seu aspecto mais importante, firmou o entendimento de que um relato crítico feito contra um agente público só poderia ser considerado difamatório se feita por má-fé (ciência de sua falsidade) ou com grave negligência quanto à atribuição equivocada de condutas - regra que, em seus termos originais, é conhecida como "actual malice or reckless disregard".

Em 1960, um chefe de polícia de Montgomery, cidade do Alabama, processou o jornal New York Times e quatro ativistas do movimento de direitos civis por considerar que havia sido pessoalmente difamado por um "anúncio público pago" publicado pelo jornal e contratado por aquele grupo - que criticava a conduta de policiais locais em episódios de manifestações públicas contra a segregação racial. A despeito de o texto criticar a operação policial de um modo geral, Sullivan, ocupante do cargo de comissário de polícia, sentiu-se pessoalmente ofendido em sua honra.

Um de seus principais argumentos era o fato de que o anúncio continha alguns erros factuais: durante um dos protestos, as pessoas haviam cantado o hino nacional, e não a música "My Country, "Tis of Thee", como havia constado no texto; embora nove estudantes tivessem sido expulsos do sistema público de educação, isso não havia ocorrido pelo protesto em frente à casa legislativa, mas sim por exigirem serem servidos na lanchonete do fórum local; a maioria (e não a totalidade) do corpo discente havia protestado contra as expulsões, recusando-se a freqüentar as aulas em um determinado dia, ao invés de deixarem de efetuar suas matrículas - entre outros argumentos afins.

A decisão da Suprema Corte reverteu uma condenação milionária imposta pelo júri local - cujo valor colocava em risco a própria existência do jornal - e fixou parâmetros liberais para a liberdade de expressão no país, especialmente ao considerar

Chicago Press, 1994, p. 2. Para Timothy Cook, "New York Times v. Sullivan seria um marco se não tivesse feito nada além de instituir as leis de difamação mais liberais do mundo. Mas igualmente importante foi a racionalidade de Brennan para essa decisão" - Timothy Cook, "Introductory Essay", in Timothy Cook (org.), Freeing the Presses: The First Amendment in action. Baton Rouge: Louisiana State University Press, 2006, p. 23. O juiz William Brennan foi o relator do voto da maioria. 
que erros factuais contidos em uma reportagem só poderiam gerar o direito a uma reparação legal se cometidos por má-fé ou grave negligência ${ }^{54}$.

A seguinte passagem se tornaria célebre: "avaliamos este caso sob o pano de fundo do profundo compromisso nacional de que o debate sobre questões públicas deve ser livre, robusto e amplo, e de que ele pode incluir veementes, cáusticos e por vezes desagradáveis e enfáticos ataques contra o governo ou servidores públicos (...). Como Madison disse, 'algum grau de abuso é inseparável do uso apropriado de tudo; e em nada isso é mais verdade do que com relação à liberdade de imprensa". A decisão conclui: “afirmações erradas são inevitáveis em um debate livre, e isso deve ser protegido para que a liberdade de expressão tenha o 'ar' ("breathing space”) de que necessita... para sobreviver".

Como resultado, a decisão da Suprema Corte limitou o alcance de ações por difamação, impondo um ônus considerável aos ocupantes de cargos públicos que pleiteassem eventuais reparações: "as garantias constitucionais determinam, a nosso ver, uma regra federal que proíbe um servidor público de obter indenização por reparação de danos por uma falsidade difamatória relacionada à sua função, ao menos que ele provê que essa atribuição foi feita por má-fé ("actual malice”) - ou seja, com conhecimento de que era falso, ou com grave negligência ("reckless disregard") sobre se era falsa ou não". 55

A decisão, entretanto, não foi construída sobre um argumento de direitos exclusivos ou próprios à imprensa. A condenação alcançava também quatro réus que

\footnotetext{
${ }^{54}$ Para um histórico completo sobre o caso: Anthony Lewis, Make No Law: The Sullivan Case and The First Amendment. New York: Vintage Books, 1992. Embora tenham concordado com o resultado, os juízes Goldberg e Douglas consignaram em votos apartados o entendimento de que o direito de crítica contra condutas de oficiais públicos seria absoluto e, portanto, não caberia sequer hipoteticamente a viabilidade de uma acusação de difamação por parte deles: "um direito absoluto de dizer o que se quer sobre questões públicas é o que eu considero ser a garantia mínima da Primeira Emenda" (Hugo Black).

${ }^{55}$ Esse aspecto até hoje não resta incontroverso. Anthony Lewis opina: "A imprensa ficou satisfeita com o fato de mais queixosos de difamação terem de arcar com o pesado ônus da prova, mas eu não fui convencido de seu acerto na época, nem depois. Se um tablóide de supermercado publica uma matéria sensacionalista sobre uma atriz de cinema, por que ela deveria fazer o mesmo que um político estaria obrigado a fazer se processasse o jornal por difamação? O que ela tem a ver com o que a decisão (...) chamou de 'o significado central da Primeira Emenda", o direito de criticar funcionários do governo? (...) Sejam quais forem as discordâncias sobre o impacto do caso (...), uma coisa é clara. A decisão finalmente eliminou a ideia de difamação sediosa nos Estados Unidos. E isso não é pouca coisa" Anthony Lewis, Liberdade para as ideias que odiamos. São Paulo: Aracati, 2011.
} 
não eram jornalistas, mas sim ativistas do movimento de direitos civis, signatários do “anúncio público pago" que motivou a acusação de difamação. A eles foi igualmente reconhecido o direito de crítica sobre a regra do "actual malice or reckless disregard". Desde então, o precedente tem sido aplicado indistintamente também a casos que não envolvem nenhum jornalista ${ }^{56}$.

$\mathrm{Na}$ análise de Timothy Cook, "a decisão [...] não foi alcançada tendo como base uma 'liberdade de imprensa' distinta. É difícil imaginar que seu voto seria diferente se fosse um caso de difamação falada, e não escrita. (...) Sullivan talvez seja melhor compreendido como um em uma série de casos sobre direitos civis, na esteira de Brown v. Board of Education. Sullivan, assim como a maior parte das decisões da Suprema Corte e de especialistas, não distingue 'liberdade de expressão' e 'liberdade de imprensa, ${ }^{57}$.

\section{3.c - Branzburg v. Hayes (1972)}

Uma controvérsia jurídica se instala nos anos 1970, quando jornalistas profissionais passam a reivindicar direitos próprios e exclusivos - como sigilo de fonte, direito de entrevistar detentos e de resistir a mandados de busca e apreensão, além de ordens judiciais. "Se a liberdade de imprensa criava direitos distintos daqueles baseados na liberdade de expressão, tornava-se, pela primeira vez, algo que deveria ser decidido" 58 .

Em 1972, a Suprema Corte decide o caso Branzburg v. Hayes. Trata-se do único caso em que aquela corte constitucional debruçou-se sobre a questão do sigilo de fonte para repórteres - e que se tornou a principal referência jurisprudencial para as cortes inferiores nas décadas seguintes ${ }^{59}$.

\footnotetext{
${ }^{56}$ David Anderson, "The Origins of the Press Clause", University of California Law Review 30 (1983), p. 457.

${ }^{57}$ Timothy Cook, "Introductory Essay", p. 5. No original: "like most Court decisions and most Court watchers, does not distinguish between 'freedom of speech' and 'freedom of the press' under the rubric of 'freedom of expression'".

${ }^{58}$ David Anderson, "Freedom of the Press in Wartime", pp. 70-71.

${ }^{59}$ Segundo Anthony Lewis, o primeiro caso em que um jornalista apresentou um argumento constitucional de proteção ao sigilo de fonte para a justiça nos Estados Unidos ocorreu em 1957. Marie Torre era colunista de televisão do New York Herald Tribune e havia publicado, citando um executivo anônimo da rede de televisão CBS, que a atriz Judy Garland, recém contratada pela emissora, não havia
} 
A decisão abarcava recursos de três casos distintos. Paul Branzburg, repórter do jornal Louisville Courier, havia escrito reportagens nas quais narrava o processo de produção e consumo de haxixe, após ter tido contato com traficantes e usuários da droga. Após a publicação, autoridades conseguiram uma ordem judicial para compelilo a identificar suas fontes. A decisão tratou também de casos de outros dois repórteres - Earl Caldwell, do New York Times, e Paul Pappas, de uma televisão de Massachusetts - que haviam feito longas entrevistas com membros do grupo "Panteras Negras" ("Black Panthers"). Eles também foram intimados a identificar suas fontes no curso de investigações criminais. Todos os repórteres se recusaram a cumprir as ordens judiciais, invocando a liberdade constitucional de imprensa, e foram considerados como incursos no delito de desobediência ("contempt of court").

Dividida em uma votação de 5 a 4, a corte não deu provimento aos recursos dos jornalistas e deixou de reconhecer a eles uma prerrogativa do sigilo de fonte decorrente de direitos constitucionais. No entanto, a composição da decisão deixou um caminho livre para que a controvérsia jurídica continuasse instalada. Seu resultado é comumente classificado como confuso ${ }^{60}$. Isso porque o próprio lado vencedor, formado por 5 votos, foi substancialmente dividido: foram quatro votos capitaneados pelo juiz White e um quinto voto redigido à parte pelo juiz Powell - este último, causa de significativa controvérsias interpretativa.

\section{3.c.i - Os quatro votos vencedores}

estreado ainda seu novo programa porque ela estava "terrivelmente gorda". Garland processou a CBS por difamação e quebra de contrato e pediu que, no âmbito do processo, fosse revelada a identidade do executivo. A jornalista se recusou a fornecê-la, pois, segundo ela, se o fizesse, "ninguém do meio iria voltar a falar comigo". Torre foi condenada por desacato e passou dez dias presa. Em sede de apelação, o juiz federal Potter Stewart, futuro integrante da Suprema Corte, não aceitou seus argumentos. A Suprema Corte recusou-se a analisar o caso. Após a prisão da jornalista, Garland desistiu do processo Anthony Lewis, Liberdade para as ideias que odiamos, pp. 103-105.

${ }^{60}$ Por exemplo: David Anderson, "Confidential Sources Reconsidered", Florida Law Review 61 (2009), pp. 889-892; Floyd Abrams, Speaking Freely: Trials of the First Amendment, p. 294 e, ainda; “A Justice's Scribbles on Journalist's Rights", The New York Times, reportagem publicada em 7.10.2007 - segundo a qual "graças a um enigmático voto concorrente do juiz Lewis F. Powell Jr.,até hoje ninguém sabe ao certo o que a decisão determina”. 
Em linhas gerais, o voto do juiz White - acompanhado por outros três juízes defende que o sigilo de fonte não decorre da proteção constitucional à imprensa.

Em um primeiro momento, White coloca em xeque a própria noção de que é socialmente conveniente garantir esse tipo de sigilo. Para ele, não é evidente a ideia de que um repórter poderia se recusar a depor a um júri caso fosse convocado para esclarecer como obteve suas informações, sob o argumento de que "é melhor escrever sobre um crime do que fazer algo para punir seu autor". Um dos fundamentos do voto de White é que, embora uma regra legal possa abrir caminho para um sigilo de fonte aos repórteres, a base constitucional americana privilegia a prerrogativa do Estado e de seus júris de investigar e punir infrações criminais.

Adicionalmente, White recusa o argumento de que o Estado poderia diferenciar juridicamente os jornalistas de demais cidadãos: "a função informativa referida pelos representantes da imprensa organizada ("organized press") nos casos ora em exame é também desempenhada por palestrantes, políticos, escritores, pesquisadores acadêmicos e dramaturgos. Praticamente qualquer autor pode razoavelmente dizer que está contribuindo para o fluxo de informações ao público. No mais, agregar valor constitucional ao julgamento sobre quem é um membro da imprensa sugere uma das poucas coisas que certamente a Primeira Emenda foi criada para evitar: condicionar o discurso à obtenção de uma licença. (...). Não há licença para a imprensa nos Estados Unidos porque, efetivamente, todos já têm uma licença, e ocasionalmente um dever, de agir como imprensa".

O voto de White deixa clara sua preocupação com a necessidade de se diferenciar "quem é ou não imprensa" como base para uma aplicação do sigilo de fonte para jornalistas: "mais cedo ou mais tarde, seria necessário definir as categorias de jornalistas que fariam jus ao privilégio - um procedimento questionável à luz da tradicional doutrina de que a liberdade de imprensa é direito de um panfletário solitário que usa papel carbono ou um mimeógrafo tanto quanto é de um grande publisher metropolitano".

\section{3.c.ii - O quinto e influente voto de minerva de Powell}


$\mathrm{O}$ voto concorrente de Powell, apesar de unir-se à maioria, pontua que o alcance daquela decisão deveria ser "naturalmente limitado". Ele defende a realização de um teste "caso a caso", a ser aplicado pelo Judiciário, para sopesar o princípio de proteção à liberdade de imprensa e a obrigação de cidadãos de fornecerem informações sobre atividades criminosas, conforme previsões legais:

"Eu adiciono esse breve voto para enfatizar o que para mim parece ser a natureza limitada da decisão da Corte. Como indicado na parte conclusiva de meu voto, a Corte aponta que nenhum assédio à imprensa deve ser tolerado. Se um jornalista acredita que uma investigação de um grande júri não está sendo conduzida de boa-fé, ele terá remédios legais para usar. De fato, se um jornalista for chamado para dar informações que dizem respeito apenas marginalmente ao objeto da investigação, ou se ele tiver outra razão para acreditar que seu depoimento implica fontes sigilosas sem uma justificativa legítima por parte da investigação, ele poderá pedir a uma corte uma ordem judicial protetiva. $\mathrm{O}$ argumento do sigilo deve ser julgado diante dos fatos por meio de uma apropriada ponderação entre a liberdade de imprensa e a obrigação de todos os cidadãos de darem relevantes depoimentos com relação a uma conduta criminal. $O$ sopesamento desses vitais interesses constitucionais e sociais em uma análise caso a caso está de acordo com a tradicional maneira de adjudicar tais questões" ${ }^{\prime \prime 1}$.

O voto de Powell foi o pendor que levou ao indeferimento dos recursos. Mas ao possibilitar uma maioria apresentando esses argumentos, ele abriu caminho para que cortes inferiores posteriormente invocassem, assim como ele, o alcance limitado daquele precedente - o que possibilitou a construção de uma linha jurisprudencial que reconhecia, em análises concretas, a prerrogativa do sigilo de fonte, conforme será

\footnotetext{
${ }^{61}$ Em 2007, foram descobertas anotações feitas por Powell após uma conferência interna com seus colegas, às vésperas do julgamento: "Vou deixar claro em meu voto - a não ser que o voto da maioria seja claro - que existe um privilégio de sigilo de fonte análogo a um privilégio comprovável por provas ("analogous to na evidentiary one"). Meu voto resume-se à minha conclusão - após ouvir diversos argumentos dos advogados e reler os memoriais do caso - que nós não devemos estabelecer um privilégio constitucional. Se fizéssemos isso, os problemas decorrentes seriam muito difíceis de prever: e,g, aplicar um privilégio de dimensões constitucionais - a grandes júris, pequenos júris, comissões parlamentares, etc... E quem são ‘jornalistas' - como defini-los?” - “A Justice's Scribbles on Journalist's Rights”, The New York Times, reportagem publicada em 7.10.2007.
} 
apontado a seguir. Sob esse prisma, é possível dizer que o placar final de votos foi, na realidade, 4-1-4.

\section{3.c.iii - Os quatro votos vencidos}

Os juízes Potter Stewart, William Brennan Jr. e Marshall subscreveram um influente voto dissidente. O juiz Willliam Douglas redigiu por si só outro voto vencido.

O voto vencido de Stewart (acompanhado pelos outros dois juízes) reconhece um privilégio qualificado de sigilo de fonte decorrente da proteção constitucional à liberdade de imprensa. A posição de Stewart se baseia em uma visão institucional de imprensa, como um "quarto poder" previsto pela Constituição americana para servir como fiscal dos três poderes oficiais ${ }^{62}$. Essa construção é cética quanto a qualquer tipo de interferência - inclusive judicial - sobre as decisões tomadas pela imprensa.

Segundo ele, “(...) o direito de um repórter de proteger sua fonte está arraigando na garantia constitucional de um livre fluxo de informações ao público. Um direito pessoal do jornalista no âmbito da Primeira Emenda ou um direito associativo de jornalistas e de fontes estão inseridos naquele amplo interesse social protegido pela Primeira Emenda".

Para Stewart, o sigilo de fonte só poderá ceder em um caso concreto se o Estado demonstrar sucessivamente que: a) há indícios de que o jornalista tem informações claramente relevantes à investigação de uma ilegalidade; b) essas informações não podem ser obtidas por meios menos danosos aos direitos decorrentes da Primeira Emenda; c) demonstrar a preponderância de interesse público sobre essa informação em relação à liberdade de imprensa ${ }^{63}$.

\footnotetext{
${ }^{62}$ O juiz Stewart iria desenvolver posteriormente essa construção. Sua “abordagem institucional” será analisada detidamente no capítulo 4 (item 4.b.i).

${ }^{63}$ É interessante notar que esse voto dissidente, ao reconhecer um "privilégio qualificado" (ou seja: não absoluto) quanto ao sigilo de fonte, estabeleceu critérios sucessivos para sua superação que são exatamente análogos à máxima da proporcionalidade nos moldes propostos por Robert Alexy (Teoria dos Direitos Fundamentais. São Paulo: Malheiros, 2008, pp. 116 e ss.): razoabilidade, necessidade e proporcionalidade em sentido estrito. As etapas foram sugeridas em manifestação do jornal New York Times, a título de amicus curiae, no processo - o que rendeu à publicação uma dura crítica do juiz Douglas, último dos vencidos em posição isolada: “O New York Times, cujas funções de reportar estão
} 


\section{3.c.iv - O legado da decisão}

"A Suprema Corte se pronunciou apenas uma vez, e o que ela disse foi ambíguo o bastante para deixar as cortes inferiores criar as proteções que entendiam necessárias e, ao mesmo tempo, encorajar legislativos estaduais a aprovarem leis de proteção ao sigilo de fonte ('shield statutes')", avalia David Anderson ${ }^{64}$.

No campo jurisprudencial, desde a decisão Branzburg em 1972, a maior parte das cortes federais passou a entender, com fundamento no voto decisivo do juiz Powell, que a Primeira Emenda conferia uma prerrogativa qualificada ${ }^{65}$ de sigilo de fonte para jornalistas em casos cíveis. Em casos criminais, em especial de competências de "grand juries", a maior parte das cortes americanas entende que essa prerrogativa não existe - embora haja exceções, inclusive em sede de cortes de apelações $^{66}$.

No geral, porém, mantém-se um quadro judicial extremamente controvertido algo causado não apenas pelas divergências interpretativas sobre o direito constitucional e o precedente de Branzburg v. Hayes, mas também pela incidência de

em jogo aqui, assume a incrível posição de que os direitos da Primeira Emenda devem ser sopesados contra outras necessidades ou conveniências do governo. Eu entendo que todo o 'sopesamento' já foi feito por aqueles que escreveram o Bill of Rights. Ao lançarem a Primeira Emenda em termos absolutos, eles repudiaram a tímida, aguada e mutilada versões que são defendidas pelo Governo e pelo New York Times neste caso".

${ }^{64}$ David Anderson, “Confidential Sources Reconsidered”, pp. 889-892. Ainda segundo o autor, "anos após essa decisão, tornou-se claro que Branzburg não apresentou o caso pela proteção constitucional ao sigilo de fonte em sua forma mais forte, por duas razões não compreendidas à época. Primeiro, Branzburg apresentou a controvérsia de ordem judicial em um contexto criminal ordinário, ao invés de um contexto de campanha de intimidação a vazamentos implementada pelo governo ("Justice Department”) (...). Segundo, as especificidades de um privilégio constitucional para repórteres, cuja criação os jornalistas pediram à Corte, tiraram sua atenção da questão fundamental - a revelação compulsória de fontes confidenciais ameaça a liberdade de imprensa? Como resultado, a Corte não decidiu essa questão. Ao invés isso, a maioria que acompanhou o voto do juiz White dedicou a maior parte de sua atenção a preocupações sobre como o privilégio iria funcionar: quem poderia invocá-lo? Quão eficaz ele seria para amenizar o receio de potenciais informantes? Como as cortes iriam determinar se as condições para o privilégio em um caso foram alcançadas? Como as cortes iriam sopesar a necessidade de revelação pública contra os interesses na manutenção do sigilo?"

${ }^{65}$ Utiliza-se aqui o termo "prerrogativa qualificada" como contraponto a uma "prerrogativa absoluta" ou seja, qualificada porque aplicável a priori. No original em ingles: "qualified privilege".

${ }^{66}$ Floyd Abrams, Speaking Freely: Trials of the First Amendment, p. 294; Editorial "Protecting the New Media: Application of the Journalist's Privilege to Bloggers", Harvard Law Review 120 (2007), pp. 998-999. 
múltiplas legislações estaduais, além de fatores de competência judicial (cível ou criminal, federal ou estadual, etc).

As controvérsias jurídicas que envolveram a jornalista Judith Miller ilustram bem esse legado de Branzburg v. Hayes. Em 2005, Miller, então do New York Times, ficou presa por 85 dias após se recusar a identificar sua fonte em uma investigação federal, feita no âmbito de um "grand jury", sobre o crime de divulgação de identidade de uma agente da CIA, Valerie Palmer. Miller não havia publicado a informação em nenhuma reportagem sua (o que por si só levantou dúvidas sobre se poderia invocar a prerrogativa de sigilo), mas foi arrolada como testemunha pelo procurador responsável pelo caso.

Ao final, descobriu-se que o responsável pelo vazamento criminoso era o chefe de gabinete do vice-presidente, que passou a informação para vários jornalistas. Miller foi solta após aceitar fornecer seu depoimento, o que fez somente depois de ter obtido a concordância de sua fonte. A Suprema Corte já havia se negado a analisar seu recurso ${ }^{67}$.

Ainda em 2005, Miller, por outro lado, beneficiou-se de uma decisão de outro juiz federal de Nova York que, ao reconhecer a prerrogativa de sigilo de fonte da jornalista nos moldes propostos pelo juiz Powell, negou um pedido daquele mesmo procurador de abrir o sigilo de todas as comunicações dela e de um colega do mesmo jornal, referente a um período de três meses, no âmbito de uma investigação de extremistas islâmicos, que teriam sido avisados sobre a realização de uma futura operação de busca e apreensão. O juiz apontou que não havia justificativas suficientes por parte do governo para superar o privilégio. No ano seguinte, no entanto, a decisão seria revertida em segunda instância, pelo placar de 2 a $1^{68}$.

Atualmente, 40 estados americanos e o distrito federal possuem leis locais que conferem proteção ao sigilo de fontes para jornalistas ("shield law statutes"). As leis variam bastante: algumas se aplicam a processos civis, excluindo expressamente

\footnotetext{
${ }^{67}$ Floyd Abrams, Speaking Freely: Trials of the First Amendment, pp. 289-302.

${ }^{68}$ Floyd Abrams, Speaking Freely: Trials of the First Amendment, pp. 295-296; "U.S. wins access to reporter phone records", The New York Times, reportagem publicada em 02.08.2006.
} 
processos criminais; outras protegem apenas a identidade das fontes, mas não outras informações correlatas; há casos que apenas formalizam proteções já garantidas pelos precedentes judiciais do respectivo estado ${ }^{69}$. Subsiste, ainda, um relevante debate sobre a conveniência de promulgação de uma lei protetiva federal.

\section{3.d - Landmark Communications v. Virginia (1978)}

Merece registro neste capítulo também o julgamento pela Suprema Corte do caso Landmark Communications v. Virginia (1978).

O jornal Virginian Pilot - que pertencia à empresa Landmark Communications - havia publicado uma reportagem sobre uma investigação disciplinar em curso contra um juiz. A legislação estadual de Virginia revestia esse procedimento de caráter sigiloso e criminalizava sua divulgação. $\mathrm{O}$ editor do jornal foi condenado em primeira instância a uma pena de multa pela publicação, em decisão mantida pelo tribunal local. A publicação recorreu à Suprema Corte, argumentando que a penalidade só poderia ser imposta a pessoas que participassem da comissão processante e tivessem o dever de sigilo - e não a jornalistas responsáveis por reportagens sobre os procedimentos. Nenhum repórter ou empregado da empresa de comunicação havia participado dos procedimentos da comissão como testemunha ou em outra qualidade afim.

A decisão afastou de modo unânime a possibilidade de condenação criminal, com fundamento na Primeira Emenda. A Suprema Corte considerou que o desempenho profissional de juízes constituía assunto de notório interesse público, o que justificava o interesse em se produzir notícias e promover críticas públicas a respeito. Embora tenha reconhecido e dado peso ao argumento de que a confidencialidade de procedimentos servisse a interesses estatais legítimos, concluiu que a imposição de sanções criminais a pessoas externas baseava-se em suposições vagas de que as punições eram necessárias para viabilizar as investigações e cultivar a credibilidade do sistema judiciário. De acordo com a decisão, "é verdade que algum risco de dano ao juiz investigado, ao sistema de justiça, ou aos trabalhos da Comissão

\footnotetext{
${ }^{69}$ Wikipedia <www.wikipedia.org>, pesquisa pelo verbete "Shield laws in the United States", acesso em 20.07.2012.
} 
Disciplinar Judicial pode ser gerado por uma divulgação prematura (...), mas muito dos riscos podem ser eliminados por cuidadosos procedimentos internos que protejam a confidencialidade dos procedimentos da Comissão".

Ainda que o caso dissesse respeito claramente ao reclamo de um jornal impresso tradicional, a opinião da Corte, redigida pelo juiz Burger, deixou bem clara a determinação do colegiado em não promover uma diferenciação de direitos dos cidadãos em geral e de jornalistas profissionais: "a estreita e limitada questão apresentada, portanto, é se a Primeira Emenda permite uma punição criminal a terceiras pessoas que são estranhas à investigação disciplinar, incluindo a imprensa ('news media'), por divulgarem ou publicarem informações verdadeiras a respeito de procedimentos confidenciais da Comissão Disciplinar Judicial. Nós não estamos aqui preocupados com a possível aplicação dessa lei a alguém que obtém as informações por meios ilegais e as divulga" (grifo meu) ${ }^{70}$.

Esse ponto em especial - que interessa ao debate desta pesquisa - motivou uma declaração de divergência, embora em voto concorrente, do juiz Potter Stewart. Em síntese, ele concordava com a posição de seus pares porque o caso tratava da publicação de uma reportagem por um veículo tradicional de imprensa - mas admitia a validade de uma punição criminal a pessoas em geral que divulgassem as informações tidas pela lei como sigilosas.

Para Potter, "o estado de Virginia publicou uma lei tornando uma infração criminal para 'qualquer pessoa' a divulgação de informações confidenciais sobre procedimentos em trâmite perante a Comissão Disciplinar Judicial. Eu não posso concordar que essa lei viola a Constituição, como aponta esta Corte. Dificilmente pode haver um interesse governamental mais forte do que o interesse de um estado na qualidade de seu judiciário (...). Eu não acho nada na Constituição que impeça Virginia de punir aqueles que violem essa confidencialidade (...). Mas, neste caso, Virginia estendeu essa lei para punir um jornal, e isso não é constitucional. Se a

\footnotetext{
${ }^{70}$ Durante as argüições do caso, o presidente da Corte, Warren Burger, indagou a James Kulp, que defendia a decisão do tribunal de Virginia, o seguinte: "se um advogado chamasse uma coletiva de imprensa para divulgar uma cópia de sua reclamação à comissão processante, isso seria ilegal; mas se fizesse uma declaração pública e não protocolasse uma reclamação formal, isso seria permitido sob a liberdade de expressão?" Kulp concordou com a hipótese. Floyd Abrams, Speaking Freely: Trials of the First Amendment, pp. 78-79.
} 
proteção constitucional à imprensa significa algo, é que o governo não pode decidir o que um jornal pode ou não publicar. Embora o governo possa negar acesso à informação e punir sua subtração ilegal ('theft'), o governo não pode proibir ou punir uma publicação daquela informação uma vez que ela caia nas mãos da imprensa, a não ser que a necessidade de sigilo seja manifestamente preponderante ("manifestly overwhelming')".

Ele admitia, assim, uma diferenciação entre imprensa e cidadãos em geral quanto ao direito de publicação e divulgação de fatos. A abordagem institucional de Stewart à liberdade de imprensa, que fundamenta esse entendimento, será apresentada no capítulo a seguir (item 4.b.i).

\section{3.e - Bartnicki v. Vopper (2001)}

Em 2001, a Suprema Corte julgou o caso Bartnicki v. Vopper. Barticki era um dos líderes sindicais de professores do estado do Wyoming. Entre os anos de 1992 e 1993, os professores entraram em uma tensa negociação coletiva com o sistema público de educação local, que envolveu paralisações dos profissionais e uma ampla cobertura por parte da imprensa.

Em um de seus programas de rádio, Vopper - que promovia uma cobertura bastante crítica ao movimento sindical - divulgou trechos de uma interceptação ilegal de uma ligação telefônica feita entre Bartnicki e outro sindicalista, dotada de um conteúdo polêmico: eles não apenas discutiam as estratégicas de paralisação, objetivos e metas para a negociação, mas também comentaram entre si que, se os gestores públicos fossem intransigentes, eles deveriam tomar alguma atitude, "como ir explodir as portas das casas dessas pessoas"71. Posteriormente, descobriu-se que a gravação foi fornecida ao jornalista por um representante de um grupo de defesa dos contribuintes, Jack Youcum, que se opunha ao movimento sindical - ele argumentou que a gravação havia sido entregue anonimamente em sua caixa de correio.

\footnotetext{
${ }^{71}$ No original: "if they're not gonna move for three percent, we're gonna have to go to their, their homes... To blow off their front porches, we'll have to do some work on some of those guys".
} 
A legislação federal e estadual proibiam não apenas a gravação ilegal de conversas telefônicas, mas também sua divulgação intencional - e não continha nenhum tipo de exceção prevista para jornalistas.

A Suprema Corte decidiu por maioria de votos que a divulgação da conversa era protegida pela Primeira Emenda - embora não tenha exatamente aceito os argumentos dos réus de que a imprensa tem o direito de publicar informações sobre questões de interesse público, ainda que obtidas ilegalmente por terceiros.

A corte assumiu as seguintes premissas em sua decisão: a interceptação da conversa havia sido ilegal e Yocum, bem como os jornalistas que divulgaram posteriormente a conversa, encontravam-se incursos em leis federais e estaduais aplicáveis, que previam o pagamento de indenização às vítimas. Restava saber, então, "se a aplicação dessas leis nessas circunstâncias violava a Primeira Emenda".

Considerando que os réus não haviam participado diretamente da interceptação ilegal e que seu conteúdo era dotado de interesse público e jornalístico ("newsworthy"), a corte promoveu um balanceamento entre o interesse de se proteger a privacidade das conversas privadas, promovida pela legislação aplicável, e o "escudo da Primeira Emenda para debates sobre questões de interesse público" - ao final, decidindo em favor deste último. O texto da decisão enfatiza reiteradamente seu caráter limitado às circunstâncias do caso concreto ${ }^{72}$.

Em nenhum momento a corte acenou que poderia haver conseqüências jurídicas distintas para Jack Youcum e Vopper. Ao contrário, a decisão pela validade da divulgação da conversa buscou analisar os aspectos objetivos daquele caso concreto, após aceitar o pressuposto de que não havia prova que qualquer um deles era o autor da interceptação telefônica.

\footnotetext{
${ }^{72}$ Os juízes Breyer e O’Connor desenvolveram em um voto concorrente e conjunto suas preocupações sobre como a decisão da maioria não garantia uma "imunidade constitucional" para a imprensa. Eles enfatizaram que a incitação ao crime mencionada na conversa divulgada, além da própria natureza pública do assunto em pauta, garantiam naquele caso uma "exceção" à proteção constitucional ao caráter privado da conversa. Vencidos os juízes Rehnquist, Scalia e Thomas, que consideram "questões de interesse público" um "conceito amorfo, que a Corte sequer tenta definir". Para eles, a decisão da maioria contrariou a Primeira Emenda exatamente por atentar contra a liberdade de as pessoas discutirem assuntos com a expectativa de privacidade.
} 
Esse raciocínio, aliado às menções genéricas à Primeira Emenda e ao "speech of public concern", reiteram a falta de disposição da Suprema Corte em reconhecer prerrogativas próprias aos jornalistas com fundamento na "liberdade de imprensa".

\section{3.f - Considerações finais do capítulo}

$\mathrm{O}$ desenvolvimento da jurisprudência norte-americana demonstra como uma conceituação sobre o significado da liberdade de imprensa nos leva a questões extremamente controversas, em geral ignoradas nos empregos usuais desse termo.

Para Scott Gant, "mais importante que seu uso de terminologias é o fato de que a Suprema Corte nunca determinou que a liberdade de imprensa ("press clause") tem qualquer significado distinto da liberdade de expressão ("speech clause") na Primeira Emenda. Em suas diversas decisões envolvendo organizações da imprensa ("media and news organizations"), a Corte baseou suas determinações no direito de liberdade de expressão que pertence igualmente à imprensa e às demais pessoas". Ao fazê-lo, "a Suprema Corte evitou decidir se há quaisquer circunstâncias sob as quais 'a imprensa' tem direitos ou privilégios constitucionais não disponíveis a todos" 73 .

A jurisprudência da Suprema Corte americana, em resumo, até hoje não reconheceu qualquer tipo de prerrogativa ou privilégio próprio aos "jornalistas" ou "membros da imprensa". Esse posicionamento resulta não apenas da relutância em se diferenciar quem está dentro ou fora desse grupo e se ele é, em si, identificável, mas também de uma compreensão histórica que aproxima o próprio jornalismo às liberdades individuais de expressão e de crítica. No mais, essa linha jurisprudencial não foi implementada sem críticas. Elas serão apresentadas no próximo capítulo, mediante uma análise das abordagens "institucional" e "funcional" à liberdade de imprensa.

\footnotetext{
${ }^{73}$ Scott Gant, We're all Journalists Now, p. 59. O autor lembra que a Suprema Corte americana decide "a portas fechadas" quais casos ela irá ou não apreciar e aponta que, nos últimos anos, diversos recursos que levantavam questões relativas à liberdade de imprensa não foram recebidos. Para ele, "os ministros têm se esforçado nas décadas recentes para evitar casos que abordam a questão sobre se a liberdade de imprensa possui qualquer significado distinto da liberdade de expressão" (pp. 71-72).
} 


\section{Capítulo 4 - Liberdade de imprensa: as abordagens "institucional" e "funcional"}

A jurisprudência constitucional norte-americana sobre a liberdade de imprensa não é incontroversa. Desde a década de 1970, autores promovem análises jurídicas sobre se a relutância da Suprema Corte em reconhecer prerrogativas próprias à imprensa é ou não acertada. A discussão ganhou novo fôlego naquele país com a massificação do uso da internet e a consolidação da importância da blogsfera no debate público.

Esse debate será apresentado neste capítulo, cujo objetivo será promover uma apresentação e análise crítica de visões que serão classificadas como "abordagem institucional" e "abordagem funcional" à liberdade de imprensa. Embora alguns autores tenham sido agrupados sob essas rubricas, obviamente há algumas distinções relevantes entre componentes do mesmo grupo, que serão tratadas a seguir.

Ao final, como hipótese de trabalho, pretende-se afastar a viabilidade de uma abordagem institucional e defender a pertinência de uma abordagem funcional à liberdade de imprensa. Como será visto, entretanto, a adoção de uma ótica funcional de imprensa (ou "jornalismo") dá início a questões igualmente controversas.

\section{4.a - Os modelos de impresa livre ("free press") e imprensa aberta (“open press")}

A judicialização de demandas por prerrogativas próprias, na esteira da profissionalização da imprensa, permite a seguinte observação: quanto mais se acredita na existência de uma técnica de reportagem e edição capaz de fornecer um relato isento e imparcial dos fatos - uma expertise restrita a um corpo de profissionais ou "membros da imprensa" - mais fácil se torna defender uma distinção entre liberdade de imprensa e liberdade de expressão. Ou seja: torna-se mais justificável defender uma diferenciação pelo Estado entre os cidadãos em geral e esse grupo de pessoas. A elas, bastaria satisfazer o ônus de justificar em que medida algumas 
prerrogativas fortalecem o exercício de sua atividade e o alcance do interesse público na disseminação de informações.

O raciocínio inverso é igualmente válido: a defesa de que os jornalistas - ainda que com o uso de técnicas consagradas, tradicionais e pretensamente objetivas de reportagem -, ao oferecerem à sociedade os seus relatos sobre temas de interesse público, exercem um atributo inerente à crítica, à expressão e à cidadania, necessariamente os confunde com os cidadãos em geral e torna mais difícil a sustentação de constitucionalidade de qualquer prerrogativa ou privilégio.

De certa maneira, o cerne desse debate pode ser condensado pela apresentação do que Robert Martin denominou de modelos de imprensa livre ("free press") e imprensa aberta ("open press"), ao promover uma análise histórica da liberdade de imprensa nos Estados Unidos desde sua época como colônia inglesa.

Para Martin, o modelo de "imprensa livre" cultiva a imprensa como a principal defensora das liberdades públicas, em seu papel de baluarte contra a tirania governamental ${ }^{74}$. É também chamada de "modelo de cão de guarda" ("watchdog model"), "o que implica dizer que a imprensa é independente do governo para garantir que jornalistas possam fiscalizar livremente as ações e palavras das autoridades, descobrindo situações de abuso de poder"75.

O modelo de "imprensa aberta", por outro lado, enfatiza "o direito individual de cada homem de expressar seus sentimentos perante os outros, independente de sua convicção política ou das consequências que isso irá gerar para a liberdade dos demais" "76. Também denominada de "marketplace of ideas model", é a racionalidade de liberdade de imprensa adotada pela Suprema Corte Americana no caso New York Times Co. v. Sullivan ${ }^{77}$.

\footnotetext{
${ }^{74}$ Robert W. T. Martin, The Free and Open Press: The Fouding of American Democratic Press Liberty, 1640-1800. New York: New York University Press, 2001, p. 3.

${ }^{75}$ Timothy Cook, "Introductory Essay", in Timothy Cook (org.), Freeing the Presses: The First Amendment in action. Baton Rouge: Louisiana State University Press, 2006, p. 3.

${ }^{76}$ Robert W. T. Martin, The Free and Open Press, p. 3

${ }^{77}$ Timothy Cook, "Introductory Essay", p. 3.
} 
Em linhas gerais, uma compreensão baseada no modelo de "imprensa livre", que atribui à liberdade de imprensa uma função institucional especializada, consistente em vigiar os poderes públicos oficiais, fornece um lastro conveniente para justificar prerrogativas e garantias exclusivas para seu exercício ${ }^{78}$. Por outro lado, essa mesma razão de ser costuma vincular a liberdade de imprensa exclusivamente à cobertura e discussões sobre "assuntos públicos e oficiais" (ligados a um dos três poderes) - uma distinção que, por si só, é bastante difícil de se sustentar ${ }^{79}$.

O modelo de "imprensa aberta" evita essa dificuldade conceitual, bem como qualquer crítica de elitismo, ao afastar a ideia de que a atividade informativa socialmente relevante deve ser desempenhada apenas por "uma elite auto-declarada". Mas não se propõe a ter o mesmo grau de efetividade e combatividade que o modelo de "imprensa livre" 80 . Corre, ainda, um maior risco de se tornar redundante à liberdade de expressão.

Para Timothy Cook, ambos os modelos procuram intensificar a autonomia da atividade jornalística. "E cada modelo contém uma hipótese implícita: que aumentar essa autonomia leva a resultados desejados, seja isso um aumento do espectro de pontos de vista expressados em um sistema político ou um aprimoramento da fiscalização pública do governo" ${ }^{\natural 1}$.

Embora esses modelos tenham coexistido nos Estados Unidos durante o período de afirmação da independência do país e de seu modelo constitucional,

\footnotetext{
78 "Entender a liberdade de imprensa ("Press Clause") sob a perspectiva de um modelo de imprensa livre ("free press") leva a uma compreensão mais específica e especializada do papel da imprensa. (...) Na medida em que a imprensa desempenha um papel estrutural de ontrole aos "ramos oficiais" do governo, está a apenas um pequeno passo de distância - embora não um que seja inevitável argumentar que a liberdade de imprensa gera algum grau de privilégios e imunidades" - Paul Horwitz, "Or Of The Blog", Nexus 11 (2006), pp. 8-9.

${ }^{79}$ Cabe aqui uma referência à tentativa de se definir se determinado assunto ou ato é "político" ou não. O que dizer sobre reportagens sobre moda, arte e comportamento, por exemplo? Além disso, no mundo contemporâneo, pode haver tanto interesse público em informações sobre os negócios de conglomerados, empresas e instituições financeiras quanto há nos clássicos exemplos de limites ao governo nos séculos passados. Nesse sentido, "na medida em que o modelo de imprensa livre ("free press') é baseado diretamente na função da imprensa como fiscal ("watchdog") do governo, ele oferece pouca base para uma proteção institucional da imprensa quando ela discute questões outras que assuntos públicos ("public affairs')" - Paul Horwitz, "Or Of The Blog", pp. 8-9.

${ }^{80}$ Paul Horwitz, "Or Of The Blog", p. 8-9.

${ }^{81}$ Timothy Cook, "Introductory Essay", p. 3.
} 
segundo análise de Robert Martin ${ }^{82}$, é razoável dizer que eles bem resumem os mais comuns argumentos valorativos em defesa de uma liberdade de imprensa em sociedades democráticas. Em relação aos problemas propostos por este trabalho, esses modelos condensam as encruzilhadas postas à interpretação constitucional.

Essa oposição entre os modelos de "imprensa livre" e "imprensa aberta" será aprofundada de forma mais detida a seguir, a partir de suas respectivas conceituações jurídicas contemporâneas no debate norte-americano: a oposição entre uma abordagem institucional e uma abordagem funcional da liberdade de imprensa.

\section{4.b - A abordagem institucional}

As principais críticas feitas à jurisprudência da Suprema Corte norteamericana partem de autores que defendem uma abordagem institucional ao conceito de liberdade de imprensa. Argumenta-se principalmente que o papel constitucional desempenhado por essa cláusula difere dos demais direitos previstos pela Primeira Emenda (liberdade de expressão, liberdade religiosa, etc) - que são, esses sim, exercidos a título individual. Os defensores dessa abordagem apontam claramente a necessidade de se abandonar a "tradicional doutrina da primeira emenda" com relação à imprensa ${ }^{83}$.

De um modo geral, a abordagem institucional defende que a interpretação constitucional deve levar em conta "instituições pré-jurídicas", afastando de si um "agnosticismo institucional" que ignora importantes diferenças históricas, estruturais, econômicas e culturais entre os diversos canais e órgãos de comunicação em uma sociedade.

\footnotetext{
${ }^{82}$ Robert W. T. Martin, The Free and Open Press, p. 3. Timothy Cook aponta que essas duas tradições de liberdade de imprensa são observadas concomitantemente em dispositivos diversos da Constituição do Estado da Pennsylvania de 1776, transcritos a seguir: "the people have a right to freedom of speech, and of writing, and publishing their sentiments; therefore the freedom of the press ought not to be restrained", bem como "the printing presses shall be free to ever person who undertakes to examine the proceedings of the legislature, or any part of government" - Timothy Cook, "Introductory Essay", p. 7. 83 "O argumento de que a imprensa pode ser protegida sob a "Press Clause" sem que se dê os mesmos direitos para todos que possam ser considerados como imprensa requer um estilo não familiar de interpretação constitucional. É difícil de aceita-lo porque ele difere de modo dramático da jurisprudência da liberdade de expressão, na qual a proibição de discriminação entre os sujeitos ('speakers') é um ponto de fé" - David Anderson, "Freedom Of The Press in Wartime", University of Colorado Law Review 77 (2006), p. 96.
} 
Sob essa visão, a imprensa é uma "instituição", cuja razão de ser é fiscalizar e promover a crítica dos três poderes públicos oficiais. Essa ideia pode ser condensada assim: para o sistema constitucional norte-americano, a imprensa é um quarto poder, exercido por um tipo especial de iniciativa comercial da sociedade civil. Esse fundamento justificaria prerrogativas próprias aos membros da imprensa "reconhecida" e "organizada" - como o sigilo de fonte, por exemplo. Essa natureza institucional distinta é a razão pela qual é incorreto tentar compreender a liberdade de imprensa como sendo um direito individual, característica esta que se aplica a outros dispositivos da Primeira Emenda.

Em geral, esses autores pontuam que a interpretação jurídica - e as cortes, em especial - já levam em consideração o papel que as instituições sociais desempenham ao julgar casos relativos às liberdades da Primeira Emenda. Para eles, assumir esse fundamento apenas daria maior transparência à lógica decisória e afastaria descompassos argumentativos ${ }^{84}$.

A seguir, serão apresentados os principais argumentos de quatro autores que integram essa corrente interpretativa, com especial ênfase às contribuições originais de cada.

\section{4.b.i - Os argumentos de Potter Stewart}

O modelo de "abordagem institucional" à liberdade de imprensa foi articulado abertamente pela primeira vez pelo então juiz da Suprema Corte americana Potter Stewart, em palestra proferida em 1974 na Faculdade de Direito de Yale ${ }^{85}$.

\footnotetext{
84 “o custo desse agnosticismo institucional é que a Suprema Corte se força para encaixar o complexo mundo real no qual o discurso ocorre nos limites de sua doutrina da Primeira Emenda, gerando uma míriade de exceções ou simplesmente distorcendo-a" - Paul Horwitz, "Or Of The Blog", p. 21. No mesmo sentido: David Anderson, "Freedom of the Press in Wartime", p. 75-78; Frederick Schauer, "Towards an Institutional First Amendment", Minnesota Law Review 89 (2005); do mesmo autor, "Principles, Institutions and First Amendment", Harvard Law Review 112 (1999). Para uma defesa da compatibilidade e complementaridade entre a abordagem institucional da Primeira Emenda e o conceito de "livre mercado de idéias": Jospeh Blocher, "Institutions in the Marketplace of Ideas", Duke Law Journal 57 (2008).

${ }^{85}$ Publicada posteriormente: Potter Stewart, "Or Of The Press", Hastings Law Journal 26 (1975). O título da palestra é uma ênfase ao respectivo trecho da Primeira Emenda constitucional americana, uma provocação sobre em que medida a "Press Clause" se diferencia da "Speech Clause": "Congress shall
} 
Para Stewart, a liberdade de imprensa é uma "norma estrutural" da Constituição americana, que garante à imprensa uma autonomia institucional que a permite ser um fiscal permanente dos poderes públicos oficiais: "ao instituírem os três ramos do Governo Federal, os Pais Fundadores ('Founders') deliberadamente criaram um sistema competitivo interno. (...) O principal propósito da garantia constitucional de uma imprensa livre foi similar: criar uma quarta instituição fora do Governo como um fiscal adicional ('adittional check') aos três ramos oficiais" ${ }^{\text {" } 86}$. A tensão e a adversariedade permanentes entre imprensa e governo seriam o resultado da própria estrutura constitucional de uma sociedade democrática - a institucionalização de um sistema de checks and balances entre cidadãos e seus governantes ${ }^{87}$.

Stewart buscava recuperar um significado autônomo à liberdade de imprensa, diante da jurisprudência da Suprema Corte que ele próprio integrava, "responsável" por torná-la uma redundância à liberdade de expressão. Para ele, a maior parte dos direitos previstos no Bill of Rights - como liberdade de expressão, liberdade de religião, vedação à auto-incriminação, entre outros - são direitos individuais. "Em contraste, a liberdade de imprensa ('Free Press Clause') concede proteção a uma instituição. Em suma, o mercado de publicações ('publishing business') é a única organização privada a que é dada explícita proteção constitucional”88. Quem seria a imprensa organizada? "Os jornais diários e outras formas estabelecidas de imprensa" 89

\section{4.b.ii - Os argumentos de Frederick Schauer}

\footnotetext{
make no law respecting an establishment of religion, or prohibiting the free exercise thereof; or abridging the freedom of speech, or of the press; or the right of the people peaceably to assemble, and to petition the Government for a redress of grievances" (negrito nosso).

${ }^{86}$ Potter Stewart, "Or Of The Press", p. 634. Também nesse sentido: Floyd Abrams, "The Press is Different: Reflections on Justice Stewart and the Autonomous Press", Hofstra Law Review 7 (1979).

${ }^{87}$ Proferida em 02/11/1974, poucos meses após a renúncia de Richard Nixon do cargo de presidente do país $(8 / 8 / 1974)$, a palestra de Stewart tornou-se uma referência para as discussões sobre a liberdade de imprensa no direito americano. Stewart começou por apontar: "as pesquisas de opinião pública que eu tenho visto indicam que alguns americanos acreditam firmemente que o último presidente e antigo vice-presidente dos Estados Unidos foram tolhidos de seus gabinentes por uma arrogante e irresponsável imprensa que havia usurpado o poder de forma ditatorial" - Potter Stewart, "Or Of The Press", p. 631.

${ }^{88}$ Potter Stewart, "Or Of The Press", p. 633.

${ }^{89}$ No original: "the daily newspapers and other established news media". Potter Stewart, "Or Of The Press", p. 631.
} 
Frederick Schauer aponta um provável motivo pelo qual a jusprudência constitucional americana tenha pouca consideração pela "identidade do autor do discurso ou do ambiente institucional em que ele ocorre" ${ }^{90}$. Historicamente, os casos mais relevantes sobre liberdade de expressão na Suprema Corte diziam respeito a ideias ou discursos de grupos "que viviam à margem da sociedade" ou que eram "ruins e com ideias perigosas a dizer" - socialistas, nazistas ou membros da Ku Klux Klan" ${ }^{91}$. "Parte dessa preocupação - de que se a Primeira Emenda fosse muito orientada por grupos ou pessoas isso iria enfraquecê-la, seja isso apropriado ou não parece ter avançado também para a questão da especificidade institucional" 92 .

Para ele, porém, é possível observar uma incoerência com relação a esse “agnosticismo institucional”. Schauer aponta que é normalmente aceito que as decisões judiciais diferenciem diversas situações e problemas a partir de categorias jurídicas abstratas e conceituais - muitas vezes de contornos confusos, quando não problemáticos.

Apesar das dificuldades intrínsecas a essas definições jurídicas - elas próprias muitas vezes casuísticas e contingentes - os juízes e demais profissionais do direito costumam desenvolver seus argumentos sempre a partir de uma suposta segurança sobre esses conceitos, mas relutam em agregar às suas razões as estruturas igualmente contigentes e variáveis do mundo real. "O que distingue categorias como discriminação por ponto de vista ("viewpoint discrimination"), regulação de conteúdo, fórum público e censura prévia de categorias como universidades, bibliotecas, eleições e a imprensa é que as primeiras existem na Primeira Emenda, enquanto as últimas existem no mundo real (...). Parece que para muitos juízes delinear os contornos dessas instituições seria uma empreitada não jurídica"93.

\footnotetext{
${ }^{90}$ Frederick Schauer, "Towards an Institutional First Amendment", p. 2. Nesse artigo, o autor desenvolve de modo mais detido algumas ideias inicialmente apresentadas em "Principles, Institutions, and The First Amendment", Harvard Law Review 112 (1998).

${ }^{91}$ Frederick Schauer, "Towards an Institutional First Amendment", p. 14.

${ }^{92}$ Frederick Schauer, "Towards an Institutional First Amendment", p. 15.

${ }^{93}$ Frederick Schauer, "Towards an Institutional First Amendment", p. 12. Outra razão adicional para esse "agnosticismo institucional" seria a retória do direito constitucional, construída sobre "argumentos de princípios" - ou seja, valorativos e universalizáveis - e, portanto, avessos às considerações baseadas nas diferenças observadas na vida real (p. 11).
} 
Para superar esse equívoco, Schauer sugere ${ }^{94}$ ser necessário identificar quais “instituições sociais existentes em geral, senão em particular, desempenham funções que a Primeira Emenda considera especialmente importantes, ou que carregam riscos que a Primeira Emenda reconhece como especialmente perigosos" ${ }^{95}$. Essas instituições devem ser "ao menos moderadamente identificáveis"96.

Esse critério constitucional, portanto, busca analisar e justificar em que medida uma instituição "pré-jurídica" desempenha os valores constitucionais pertinentes. A partir desse critério inicial, a jurisprudência constitucional poderia de modo mais aberto e consciente tratar essas instituições a partir de regras - às quais caberia a missão de estabilizar relações jurídicas concretas e determinar eventuais tratamentos diferenciados.

Schauer exemplifica: "se há um privilégio de sigilo de fonte para repórteres, por exemplo, não devemos nos perguntar se um determinado exercício desse privilégio serve a propósitos da Primeira Emenda, mas sim se a pessoa que o reclama é ou não um repórter. Obviamente, definir a categoria de pessoas que terão direito a esse privilégio será algo baseado tanto nas razões para se ter o privilégio, quanto nas razões para alocá-lo em uma instituição em particular, mas os casos concretos consistirão, em sua grande maioria, na aplicação de uma regra, em vez de se aplicar a eles as razões que fundamentam essa regra"97",

Schauer entende que uma jurisprudência indisposta a diferenciar o panfleteiro solitário, o blogueiro e o repórter profissional promove a tendência de não reconhecer prerrogativas a qualquer um deles. O custo constitucional (argumentativo, jurídico e de impacto social) de universalização de prerrogativas seria tão elevado que, ao final, as prerrogativas se tornam tênues ou inexistentes - como no próprio caso americano ${ }^{98}$.

\footnotetext{
${ }^{94}$ É importante ressaltar que o objetivo principal declarado de Schauer é promover uma crítica ao "agnosticismo institucional" do direito constitucional americano no âmbito da Primeira Emenda - e, apenas em menor grau, rascunhar um esboço sobre como essa abordagem institucional efetivamente ocorreria - Frederick Schauer, "Towards an Institutional First Amendment", p. 27.

${ }^{95}$ Frederick Schauer, "Towards an Institutional First Amendment", p. 21.

${ }^{96}$ Frederick Schauer, "Towards an Institutional First Amendment”, p. 23.

${ }^{97}$ Frederick Schauer, "Towards an Institutional First Amendment", p. 23.

${ }^{98}$ Frederick Schauer, "Towards an Institutional First Amendment", p. 20. No mesmo sentido: David Anderson, "Freedom of the Press", p. 510.
} 
No limite, Schauer entende que não há um fundamento moral e individual forte para a liberdade de expressão. Para ele, a maior parte dos fundamentos aceitos para esse direito sempre parte da premissa do benefício que a livre circulação de ideias produz para a sociedade. "Se aceitarmos a Primeira Emenda porque ela promove os valores de um mercado livre de ideias ou de facilitação da busca pela verdade, ou os valores de fiscalização de abusos governamentais, ou ainda os valores de facilitar as deliberações democráticas entre as pessoas, por exemplo, então iremos perceber que o direito à liberdade de expressão não possui um fundamento moral, mas é empiricamente contingente e instrumental a algo mais profundo. (...) então, seria muito menos estranho pensar nele em termos empíricos e contingentes do que compreendê-lo simplesmente como uma incorporação de um direito humano irredutível" 99 .

\section{4.b.iii - Os argumentos de David Anderson}

David Anderson igualmente promove a defesa de uma abordagem institucional à liberdade de imprensa. Em um de seus textos, faz isso com uma preocupação bastante específica para a realidade norte-americana: para ele, somente é possível pensar na garantia de uma imprensa livre e independente na cobertura de guerras se a proteção jurídica da "Press Clause" possuir um significado distinto da "Speech Clause" ${ }^{\prime 100}$.

Anderson admite que um direito constitucional de garantia de coberturas de guerra seria "difícil de definir e de administrar", mas defende que há circunstâncias em que as cortes devem reconhecê-lo e aplicá-lo. "Pode-se considerar que uma proibição completa de acesso - a uma zona de guerra, a prisões, à equipe que conduz a batalha, a seus líderes - é presumivelmente inconstitucional”. Se a presença direta

\footnotetext{
${ }^{99}$ Frederick Schauer, “Towards an Institutional First Amendment”, pp. 15-16.

${ }^{100}$ Anderson contextualiza sua preocupação. Para ele, o último conflito armado em que repórteres cobriram livremente as zonas de batalha foi a Guerra do Vietnã. Desde então, inclusive pelo forte papel que a imprensa desempenhou para a opinião pública naquela oportunidade, o Pentágono tem controlado o acesso de jornalistas a batalhões, prisões militares e afins, além de restringir previamente, mediante autorização ou vedação, a divulgação de imagens feitas. $\mathrm{O}$ autor analisa a política do governo para a imprensa nos conflitos de Grenada (1983), Panama (1989), Golfo Pérsico (1991), Somalia (1992), Kosovo (1999), Afeganistão e Iraque (2002) - David Anderson, "Freedom of Press in Wartime”, pp. 53-64.
} 
de jornalistas em uma operação militar não é possível, em razão de justificativas concretas e específicas, deve ser garantida a eles uma "segunda melhor opção": entrevistas logo após operações, imagens em campo, etc. Ele reconhece que os direitos que propõe são limitados, mas entende que seu reconhecimento preservaria uma "influência jurídica positiva" ao contexto norte-americano ${ }^{101}$.

No entanto, "um direito constitucional à cobertura de guerra seria impossível de administrar se desse a toda a pessoa que pudesse plausivelmente argumentar que é um jornalista o direito de acompanhar tropas, questionar comandantes ou entrevistar prisioneiros. (...) isso sem mencionar qualquer um que possa vir com uma definição ampla o suficiente para incluir blogueiros ou outros que desempenhem alguma das funções da imprensa tradicional ${ }^{102 \%}$.

Por isso, Anderson considera que a proteção constitucional à imprensa produziria juízos de inconstitucionalidade apenas quando ações ou omissões colocassem em risco o papel estrutural da imprensa na sociedade. Isso ocorreria em casos de obstáculos que impedissem um fluxo relevante de informações sobre questões públicas - e não todas as vezes que uma determinada pessoa, ainda que membro da imprensa, buscasse proteção judicial para garantir sua capacidade de disseminar informações ${ }^{103}$.

Ele não se propõe, entretanto, a desenvolver essa abordagem institucional a partir de um conceito claro de imprensa: "eu argumento que as cortes devem definir os contornos do conceito constitucional de 'imprensa' gradativamente, em uma

\footnotetext{
101 David Anderson, "Freedom of Press in Wartime”, pp. 91-95. Ele cita como um de seus exemplos a tentativa frustrada - judicializada com resultado negativo em segunda instância e cujo recurso não foi aceito pela Suprema Corte - da revista Hustler de obter uma ordem judicial para autorizar seu repórter a acompanhar as tropas militares na invasão do Afeganistão em 2002, conflito no qual considera ter havido um controle agudo do fluxo de informações por parte do governo (p. 65).

${ }^{102}$ David Anderson, "Freedom of Press in Wartime", p. 95.

103 "Seria necessário em um cenário como esse um conceito constitucional capaz de reconhecer e enfrentar uma ameaça coordenada à imprensa. A jurisprudência de liberdade de imprensa até o momento não possui esse viés, mas a 'Press Clause' pode oferecer uma plataforma mais promissora para desenvolvê-lo do que a 'Speech Clause'. (...) A 'Press Clause' não deveria ser invocada para impedir todas as interferências à habilidade da imprensa de informar o público. Negar acesso a indivíduos, ou até mesmo a grupos inteiros da imprensa, não deveria ser tratado como violação à 'Press Clause' ipso facto. A 'Press Clause' deveria ser reservada para interferências que ameaçam seriamente a habilidade da imprensa de desempenhar suas funções históricas" - David Anderson, "Freedom of the Press", p. 525. No mesmo sentido: "Freedom of Press in Wartime", p. 96.
} 
análise caso-a-caso, assim como elas fazem com outros conceitos constitucionais, como 'discurso' ('speech') e religião. Em sua maior parte, meu argumento não necessita de uma definição precisa de imprensa. Para meus propósitos, é suficiente dizer que 'a imprensa' é qualquer entidade que possa plausivelmente ser considerada como referida pela 'Press Clause'" ${ }^{104}$.

No mais, se a constituição não demanda que se universalize os privilégios da imprensa, torna-se possível que regras infraconstitucionais modulem essas preferências de modo casuístico e com maior liberdade, por meio de regras que prevejam condutas e situações objetivas ${ }^{105}$.

Ele desenvolve esse argumento especificamente para o sigilo de fonte no contexto do direito americano. Para Anderson, "a melhor solução para o problema da confidencialidade de fontes seria uma que reconhece que a revelação forçada da fonte jornalística pode ameaçar a liberdade de imprensa de modo sério o bastante para ser inconstitucional, mas deixa o remédio para isso em grande medida com a legislação ou a common law" 106 .

Ou seja: ainda que o judiciário decida em determinados casos graves que obrigar um jornalista a revelar sua fonte é inconstitucional, quando for constatada uma ameaça relevante à função institucional da imprensa, apenas regras específicas definidas pela legislação ou common law podem dar conta de regulamentar diversos aspectos polêmicos sobre esse assunto.

\section{4.b.iv - Os argumentos de Paul Horwitz}

A abordagem institucional não significa necessariamente, entretanto, uma proteção exclusiva à imprensa "tradicional". Paul Horwitz mantém a defesa de uma abordagem institucional à liberdade de imprensa, mas busca diferenciar a proteção jurídica conferida por ela aos âmbitos institucionais da "imprensa tradicional" e da

\footnotetext{
${ }^{104}$ David Anderson, "Freedom of Press in Wartime", p. 52.

${ }^{105}$ David Anderson, "Freedom of the Press", p. 517.

${ }^{106}$ David Anderson, "Confidential Sources Reconsidered", p. 905.
} 
"blogsfera" - esta última também faria jus a essa proteção constitucional, mas de modo diferenciado se comparado à primeira.

Para Horwitz, blogs não terão necessariamente as mesmas proteções que a imprensa tradicional: "cada instituição deveria ser protegida em larga medida de acordo com suas normas internas - normas em evolução, no caso da blogsfera" ${ }^{107}$. Horwitz não se propõe a dar respostas práticas definitivas a essa questão, mas explicita que a definição do âmbito de proteção garantido pela "Press Clause" aos blogs deve levar em conta a maneira peculiar como esse meio contribui ao "discurso democrático" 108 .

Ele cita um exemplo: uma credencial de imprensa poderia ser negada a um blogueiro pelo poder público em um determinado evento, sob o argumento de que a maior parte dos blogs apenas reproduz o que é narrado pela "imprensa profissional convencional". Essa distinção nem sempre seria prejudicial: por outro lado, a jurisprudência em casos de difamação pode tornar-se mais favorável a esses veículos em consideração à facilidade de edição ou atualização de informações, à postagem de comentários por diversos usuários ou mesmo à prática de links mútuos entre diversas fontes e publicações ${ }^{109}$.

\section{4.c - A abordagem funcional}

Em 1972, o governo federal intimou o professor Samuel Popkin, da universidade de Harvard, a comparecer perante um grande júri e identificar as fontes que utilizou para escrever um artigo acadêmico sobre a guerra do Vietnã. A investigação relacionava-se à divulgação, então ainda recente, dos Pentagon

\footnotetext{
107 Paul Horwitz, “Or Of The Blog”, p. 20.

108 “(...) uma abordagem institucional para o tratamento de blogs sob a 'Press Clause' iria encorajar as cortes a considerá-los de modo mais consciente em seu contexto: dar a blogs uma autonomia substancial, enquanto monitora-se o desenvolvimento das normas de comportamento da blogsfera, e encorajar os blogs a desenvolverem regras de conduta que detenham o pior das condutas sociais que emergem nesse ambiente. Isso iria encorajar as cortes a desenvolverem um direito constitucional de blogging que permite que as normas legais relevantes emerjam das normas culturais que os blogs desenvolvem por conta própria. Nesse sentido, nosso direito constitucional, seja com relação aos blogs ou à imprensa, universidades, bibliotecas e outras instituições de Primeira Emenda, seria o produto de um diálogo orgânico sobre normas legais, constitucionais e culturais, tanto dentro quanto fora de nossas cortes" - Paul Horwitz, "Or Of The Blog”, pp. 31-32.

${ }^{109}$ Paul Horwitz, “Or Of The Blog”, pp. 25-32.
} 
Papers $^{110}$. Ele se recusou a fazê-lo sob o argumento de que suas fontes eram confidenciais e foi preso por dez dias - até o júri ser dissolvido, após impunações pelo seu advogado ${ }^{111}$. Sobre esse caso, Anthony Lewis indaga: "suponha que um professor visite o Vietnã durante a guerra, fale com oficiais americanos sobre o compromisso de que ele não iria revelar seus nomes e escreva um artigo acadêmico sobre o conflito - e seja então chamado perante um grande júri para identificar suas fontes. Se ele argumentar ter o direito de sigilo de fonte, isso não terá peso algum porque ele não é um membro da 'imprensa organizada'?" 112.

Essa indagação principal motiva um grupo de autores que defende como consistente a negativa da Suprema Corte em diferenciar direitos exclusivos para jornalistas com relação aos cidadãos em geral. Em linhas gerais, esse grupo concebe que a "liberdade de imprensa" deve ser compreendida como um direito individual, desde que esteja caracterizado um aspecto funcional, geralmente apresentado como a atividade de coleta e disseminação ao público de informações socialmente relevantes.

Para Scott Gant, "na verdade, o povo é a imprensa. Jornalismo é uma atividade, e não um título profissional. Qualquer um de nós pode se engajar nisso, a qualquer tempo, se assim escolhermos" ${ }^{113}$. A proteção constitucional à imprensa torna-se, sob essa conceção, uma proteção a uma determinada atividade: "se a Primeira Emenda dá à 'imprensa' quaisquer preferências, elas pertencem a qualquer um engajado em atividades de imprensa - o profissional e o novato, o bem pago e o voluntário, o desapaixonado neutro e o abertamente partidário" 114.

Anthony Lewis critica a possibilidade do que chama de "posição preferencial para a imprensa". Para ele, nem o texto constitucional americano, nem a própria história da proteção à liberdade de imprensa naquele país possibilitam que o Estado

\footnotetext{
${ }^{110}$ Sobre o caso Pentagon Papers, ver introdução do capítulo 3.

${ }^{111}$ Anthony Lewis, Liberdade para as ideias que odiamos, pp. 107-108. Ainda sobre o caso: "Popkin faces jail sentence in contempt of court case", The Harvard Crimson, reportagem publicada na edição de 22.3.1972, disponível em <http://theharvardcrimson.com/article/1972/3/22/popkin-faces-jailsentence-in-contempt/>

${ }^{112}$ Anthony Lewis, “A Preferred Position for Journalism?”, Hofstra Law Review 7 (1979), p. 602.

${ }^{113}$ Scott Gant, We're All Journalists Now, pp. 81-82.

${ }^{114}$ Scott Gant, We're All Journalists Now, p. 86. Para o autor, "devemos começar a avaliar as leis e políticas que expressa ou efetivamente criem preferências à mídia estabelecida com relação a outras, e garantir que elas não se afastem da letra ou do espírito da garantia constitucional à equidade" (p. 127).
} 
aja com base nessa diferenciação conceitual ${ }^{115}$. "Se os tribunais tiverem de definir, caso a caso, quem está qualificado para ter privilégio testemunhal e quem não, passarão a emitir algo semelhante às licenças para exercício da profíssão de jornalistas - que são exigidas em alguns países, mas são um completo anátema para a imprensa americana, que considera corretamente o licenciamento da imprensa uma forma de controle oficial" ${ }^{116}$.

Lewis entende, ainda, que essa diferenciação - além implicar um alto custo jurídico e político no debate social - é prejudicial à própria imprensa profissional, cujo sucesso depende não apenas de uma compreensão sobre suas funções, mas também de um consequente apoio público ${ }^{117}$. "Isso separaria a imprensa profissional do público que ela representa e aumentaria o risco da arrogância" ${ }^{118}$.

Mary Rose Papandrea rechaça a idéia de que é possível separar “jornalistas de verdade" dos "demais", pois isso seria um requisito análogo à exigência pelo Estado de diploma ou autorização para a profissão ${ }^{119}$. Do mesmo modo, ela afasta a idéia de que a informação deve ter sido divulgada em publicação com o intuito de lucro, pois seria um critério incompatível com a razão de ser da proteção constitucional à liberdade de expressão ${ }^{120}$.

\footnotetext{
${ }^{115}$ Para a crítica do autor especialmente voltada à defesa da imprensa institucional por Potter Stewart, ver: Anthony Lewis, “A Preferred Position for Journalism?”, Hofstra Law Review 7 (1979).

${ }^{116}$ Anthony Lewis, Liberdade para as ideias que odiamos, p. 114.

${ }^{117}$ Anthony Lewis, “A Preferred Position for Journalism?”, p. 609.

${ }^{118}$ Anthony Lewis, "A Preferred Position for Journalism?", p. 626.

119 "Alguns sugeriram que a pessoa afirmando seu direito deveria demonstrar algum tipo de 'credencial' ('bona fide'), como ser membro de algum grupo ou organização (cuja função seja obter informações com o propósito de disseminação ao público), ou talvez alguma educação formal, experiência e credenciais. Embora esse método tenha algum apelo como modo de diferenciar os "jornalistas reais" dos "diaristas de poltrona", é muito próximo à ideia de licença para imprensa para ser considerado constitucional" - Mary-Rose Papandrea, "Citizen Journalism and the Reporter's Privilege”, Minnesota Law Review 91 (2007), p. 575. De um modo geral, é a aversão histórica à licença prévia que motiva a tradição norte-americana pela inconstitucionalidade de eventual obrigatoriedade de diploma universitário para o exercício do jornalismo.

120 "Condicionar a prerrogativa à prova de que o indivíduo lucra com sua publicação é também injustificado. Um significado essencial da Primeira Emenda é que as publicações não fazem jus - nem são impedidas - de obter proteção da Primeira Emenda porque elas fazem ou não dinheiro. Quanto mais impopular é o discurso ("speaker"), menor será a probabilidade de que a pessoa possa lucrar com suas publicações. Muitas publicações legítimas, como jornais universitários ou publicações underground, em regra não fazem dinheiro algum, ou o fazem por anúncios publicitários e têm repórteres e editores que trabalham de graça" - Mary-Rose Papandrea, "Citizen Journalism and the Reporter's Privilege", p. 576.
} 
Sob esse ponto de vista, torna-se necessário avaliar se cada organização ou indivíduo engaja-se em uma atividade de jornalismo - ou seja, em uma atividade que pode ser compreendida como aquela constitui a razão de ser da proteção constitucional à imprensa. As distinções e privilégios promovidos pelo Estado, embora possíveis, devem ser embasadas em sólidas razões. O caráter profissional e o intuito de lucro, entretanto, tornam-se irrelevantes, pois o jornalismo deve ser compreendido não como uma profissão, mas sim como uma atividade, passível de ser exercida por qualquer um, em plataformas diversas (pesquisas acadêmicas, documentários, livros, blogs, etc). Em certa medida, essa visão é um dos pilares do voto do juiz White - acompanhado pela maioria de seus pares - no julgamento de Branzburg v. Hayes (1972) pela Suprema Corte americana ${ }^{121}$.

\section{4.c.i. - Apresentação de casos da jurisprudência norte-americana}

Já apontamos anteriormente que a aplicação ou negação do sigilo de fonte no direito americano é até hoje um assunto bastante controvertido ${ }^{122}$. No entanto, a apresentação de alguns casos selecionados ilustra a significativa receptividade de algumas decisões judiciais daquele país a uma abordagem funcional à liberdade de imprensa.

Em von Bulow v. von Bulow (1987) o tribunal do segundo circuito analisou o pedido de sigilo de fonte de Andrea Reynolds, uma escritora que recebeu uma ordem judicial para fornecer suas anotações do livro que escrevia sobre um crime de grande repercussão. O pedido havia sido feito pela família da vítima, no âmbito de uma ação indenizatória. A corte decidiu que o sigilo de fonte deveria ser concedido para todos que têm a intenção de disseminar informações ao público, desde o momento de sua coleta, independente de qualificação profisssional ou do meio de divulgação. No caso específico, contudo, a proteção foi negada a Andrea, por não ter comprovado que desde a época de sua pesquisa ela planejava divulgar as informações.

Esse precedente foi igualmente aplicado pelos tribunais do nono e do primeiro circuito. Em Shoen v. Shoen (1993), o tribunal do nono circuito aplicou a regra do

\footnotetext{
${ }^{121}$ A esse respeito, ver o capítulo 3 (item 3.c).

${ }^{122}$ Capítulo 3 (item 3.c.iv).
} 
caso von Bulow e reconheceu o sigilo de fonte para o escritor de um livro não fictício. "Autores de livros investigativos, assim como repórteres convencionais, têm historicamente desempenhado um papel vital em trazer à luz alguns fatos dignos de notícias sobre assuntos controversos de grande importância pública", aponta a decisão $^{123}$.

Em Cusumano v. Microsoft Corp (1998), o tribunal do primeiro circuito aplicou o precedente von Bulow para garantir o sigilo de fonte a professores universitários que tinham escrito um livro sobre a disputa corporativa entre Microsoft e Netscape. Para a decisão, os pesquisadores tinham o direito ao sigilo porque, "eles também pesquisam e disseminam informações. (...) Assim como jornalistas, que despidos de suas fontas teriam menos a escrever, um acadêmico, sem suas fontes, também forneceria menos análises".

Claramente, contudo, nem sempre os fundamentos da abordagem funcional à liberdade de imprensa são aceitos no âmbito judicial. Em 2001, a texana Vanessa Leggett, então professora universitária na área de justiça criminal, decidiu escrever um livro não fictício sobre o assassinato de uma socialite ocorrido em 1997, na cidade de Houston. Ela nunca havia escrito ou publicado nada anteriormente e não era uma jornalista profissional ${ }^{124}$.

Durante sua pesquisa, Vanessa entrevistou por diversas vezes Roger Angleton, cunhado da vítima, que estava preso após ser acusado de ser um dos autores do crime. Roger sucidiou-se posteriormente na prisão, deixando uma carta na qual confessava o crime. Mas como a polícia continuava a investigar o marido da vítima (Robert) - e Roger não mais podia testemunhar - as autoridades pediram a Vanessa que lhes fornecesse o material colhido durante suas entrevistas com Roger. Inicialmente, ela aceitou o pedido e entregou o conteúdo solicitado. No entanto, em uma oportunidade posterior, após receber uma ordem do júri a pedido das autoridades, ela se negou a fornecer as gravações com todas as entrevistas gravadas com terceiros com quem conversou a respeito de Robert. Vanessa não se negava a fornecer informações que

\footnotetext{
${ }^{123}$ A decisão cita os exemplos de Ralph Nader, Upton Sinclair, Bob Woodward, entre outros.

${ }^{124}$ Para um histórico sobre o caso: Anthony Lewis, Liberdade para as ideias que odiamos, pp. 113;

"Writer who was jailed in notes dispute is freed", The New York Times, reportagem publicada em 5.01.2002.
} 
tinha obtido durante suas entrevistas, mas argumentou que tinha o direito de proteger o sigilo de suas fontes. As autoridades argumentaram que o livro de Vanessa não tinha sido contratado por nenhuma editora, além do fato de ela não ser um "membro da imprensa". Com sua negativa, Vanessa ficou presa por 168 dias.

\section{4.c.ii - O caso Wikileaks}

Mencionado no capítulo introdutório deste trabalho, o caso do website Wikileaks é bastante emblemático para ilustrar a discussão "o que constitui jornalismo" no contexto da abordagem funcional à liberdade de imprensa.

Em 2010, o Wikileaks alcançou notoriedade global por ter publicado, em parceria com diversos veículos tradicionais de imprensa, comunicações sigilosas de representações diplomáticas norte-americanas ao redor do mundo ${ }^{125}$. O volume de informações coletado pela organização - cerca de 250 mil documentos - denota a extensão da variedade de assuntos, países e circunstâncias envolvidos, com diferentes graus de relevância ${ }^{126}$. Meses antes, esse veículo já havia divulgado em uma "coletiva de imprensa" um vídeo intitulado "Dano Colateral", em que demonstrava um ataque aéreo do exército americano a civis e jornalistas da agência de notícias Reuters em meio a uma batalha urbana. Em abril de 2011, o Wikileaks também foi responsável por divulgar documentos secretos do governo americano que veiculavam informações sobre prisões, investigações e acusações a que foram submetidos os detentos suspeitos de terrorismo da base militar de Guantánamo, em Cuba ${ }^{127}$.

\footnotetext{
${ }^{125}$ Para um relato detalhado sobre as atividades do Wikileaks: Yochai Benkler, A Free Irresponsible Press: Wikileaks and the Battle over the Soul of The Networked Fourth State, versão preliminar de artigo a ser publicado pela Harvard Civil Rights-Civil Liberties Law Review, pp. 4-15 <disponível em http://benkler.org/Benkler_Wikileaks_current.pdf, último acesso em 03.01.2013>.

126 A título exemplificativo, alguns jornalistas e analistas de relações internacionais anotaram que a publicação pelo Wikileaks de cabos diplomáticos americanos contendo relatos de corrupção no governo tunisiano de Ben Ali, somada à capacidade de articulação social por meio de redes de relacionamento na internet, desempenharam um papel auxiliar ao movimento popular que o derrubou do poder após 23 anos na presidência do país, diante de um quadro de forte crise econômica e desemprego entre jovens. A Tunísia forneceu o primeiro bem-sucedido exemplo revoltoso da chamada "Primavera Árabe".

${ }^{127}$ Embora o Wikileaks tenha sido responsável por uma parcela dessas publicações, parte desse material foi proveniente de outras fontes, sob condição de anonimato. Entre os jornais que publicaram o material em primeira mão, destacam-se New York Times, Washington Post, Miami Herald, The Guardian, Le Monde e a agência Associated Press. A esse respeito: "Classified Files Offer New Insights Into Detainees", New York Times, reportagem publicada em 24.04.2011.
} 
Não se discute apenas se o que esse website faz é jornalismo, mas também sobre se seus editores podem ser judicialmente compelidos a fornecerem suas fontes ou se têm o direito de invocar um direito de sigilo.

Boa parte desse debate ocorre no âmbito dos próprios veículos tradicionais de comunicação. Para Demetrio Magnoli, “o Wikileaks não é imprensa - e, num sentido crucial representa o avesso do jornalismo. O Wikileaks publica - ou ameaça publicar, o que dá no mesmo - tudo o que cai nas suas mãos. Assange pretende atingir aquilo que julga serem 'poderes malignos' (...). A imprensa não publica tudo o que obtém. $O$ jornalismo reconhece o direito à confidencialidade no intercâmbio normal de análises que circulam nas agências de Estado, nas instituições públicas e nas empresas"128.

Tim Bradshaw, por outro lado, aponta que "sua ênfase na verificação dos dados colhidos e na proteção de suas fontes é testemunho de uma tradição jornalística mais longa. Sua ascensão é concomitante à redução da capacidade dos jornais de investir em jornalismo investigativo, prejudicada pela queda na circulação e as dificuldades em ganhar dinheiro com a internet" ${ }^{129}$.

O debate sobre a natureza das atividades do Wikileaks perdura até o momento da elaboração desta dissertação. Ainda diante de um futuro incerto, discute-se se Julian Assange, o responsável por essa organização, deve ser tratado nos Estados Unidos como um jornalista ou como um inimigo de Estado, a ser enquadrado na Lei Anti-Espionagem (Espionage Act) de 1917.

Yochai Benkler debruçou-se sobre o caso Wikileaks de maneira detida e considera que essa organização deve ser compreendida como mais um componente próprio da esfera de debate público contemporânea, que é descentralizada e pautada pela informalidade - um "quarto poder em rede e sem eixo" ${ }^{130}$.

\footnotetext{
${ }^{128}$ Demétrio Magnoli, "Herói sem nenhum caráter", O Estado de S. Paulo, artigo publicado em 23.12.2010. Floyd Abrams argumenta em sentido parecido, traçando um paralelo com o caso Pentagon Papers, no qual atuou: "Why Wikileaks is Unlike the Pentagon Papers", The Wall Street Journal, artigo publicado em 29.12.2010.

${ }^{129}$ Tim Bradshaw, "Etos de site tem raiz em cultura dos hackers", Folha de S. Paulo, artigo publicado em 27.07.2010.

${ }^{130}$ Yochai Benkler, "A Free Irresponsible Press: Wikileaks and the Battle over the Soul of The Networked Fourth State", p. 37
} 
Ele anota que, diante das controvérsias que envolveram o Wikileaks ao longo de 2011 - o que incluiu, por exemplo, afirmações públicas de autoridades e parlamentares americanos de que o site era uma "organização terrorista" -, uma das estratégias de defesa assumida, entre outras, foi afirmar uma "identidade sóciopolítica de jornalismo" ${ }^{131}$. Adicionalmente, embora anote que a Lei Anti-Espionagem esteja formalmente em vigor nos Estados Unidos, considera que, sob uma ótica da “cultura constitucional”, invocá-la para reprimir uma expressão pública remete à aplicação da Sedition Act de $1789^{132}$.

Para Benkler, apenas uma abordagem funcional à liberdade de imprensa faz sentido diante da realidade contemporânea do debate público - e, em especial, diante das características promovidas pela massificação da internet. Sobre essa premissa, o Wikileaks deve ser considerado um veículo jornalístisco e, como corolário, ser reconhecida a ele a prerrogativa do sigilo de fonte. "O elemento crítico deve ser a intenção de distribuir informações no momento de sua colheita e a função desempenhada - e não o modo de disseminação. Ou seja, intenção de colher informações para disseminação pública. Simplesmente não há a mais remota dúvida de que o inteiro propósito do Wikileaks é colher informações para disseminação pública; e o uso dos veículos de mídia tradicionais para isso enfatiza esse fato, embora não seja constitutivo ou necessário para essa defesa" ${ }^{133}$.

Benkler entende que é exatamente o déficit de reconhecimento do Wikileaks como um membro legítimo do "quarto poder" que torna ainda mais necessária sua proteção constitucional como imprensa: “funcionalmente, é mais importante conceder

\footnotetext{
${ }^{131}$ Yochai Benkler, “A Free Irresponsible Press: Wikileaks and the Battle over the Soul of The Networked Fourth State”, p. 30.

${ }^{132}$ Yochai Benkler, "A Free Irresponsible Press: Wikileaks and the Battle over the Soul of The Networked Fourth State”, p. 22.

${ }^{133}$ Yochai Benkler, "A Free Irresponsible Press: Wikileaks and the Battle over the Soul of The Networked Fourth State”, p. 40. Em sentido contrário, Jonathan Peters entende que o Wikileaks não faz jus ao sigilo de fonte sob a atual jurisprudência norte-americana. Entre seus argumentos principais, ele diz que o website não desenvolve reportagens investigativas, mas sim apenas divulga documentos recebidos; além disso, não haveria preocupação editorial com consequências de interesse público, como risco a vida de terceiros - Jonathan Peters, "Wikileaks Would Not Qualify to Claim Federal Reporter's Privilege in Any Form”, Federal Communications Law Journal 63 (2011). Peters defendeu posteriormente, contudo, que a jurisprudência evolua para garantir o sigilo de fonte a websites como o Wikileaks, mas de modo mais limitado e relativo se comparado ao jornalismo tradicional - "Wikileaks shows need for a Legal 'Watchdog Privilege”, Wired, artigo publicado em 20.05.2011.
} 
proteção constitucional robusta aos membros mais fracos do quarto poder, que têm menos visibilidade pública e sofrem com as pressões das autoridades, do que é enfatizar os direitos dos membros da imprensa que são mais fortes sob critérios econômicos ou organizacionais" ${ }^{134}$.

\section{4.d - O julgamento do recurso extraordinário $n^{0} 511.961$ pelo STF e a} afirmação de argumentos tendentes a um modelo de imprensa aberta

Após a apresentação dos itens anteriores deste capítulo, torna-se conveniente invocá-los para promover uma análise da recente decisão do Supremo Tribunal Federal pela inconstitucionalidade da obrigatoriedade de diploma de jornalismo para seu exercício profissional, já apontada na introdução deste trabalho como um importante precedente para o direito constitucional brasileiro ${ }^{135}$. Conforme a leitura que será desenvolvida neste tópico, a lógica subjacente à decisão parece aproximar-se de um modelo de "imprensa aberta" (“open press"), nos moldes já expostos.

Inicialmente, vale ser feito um comentário preliminar. No Brasil, por razões bastante peculiares, não é possível debruçar-se sobre uma decisão isolada do STF por mais importante que seja - e a partir dela buscar extrair caminhos ou mesmo conclusões seguras sobre a jurisprudência constitucional. É possível dizer que, em regra, as decisões do STF não são resultados de uma deliberação coletiva prévia de seus ministros. Seus votos - mesmo quando majoritários ou unânimes frequentemente traduzem as colocações de um único magistrado; adicionalmente, ainda que em um mesmo julgamento, votos parecem não dialogar entre si. Um último fato preponderante contribui para uma falta de coerência decisória: as decisões do $\mathrm{STF}$, principalmente em processos importantes e rumorosos, com frequência transbordam as questões trazidas pelo caso concreto e levam os ministros a se dedicarem a longas argumentações doutrinárias e conceituais - o que costuma minimizar a clareza de suas razões de decidir e potencializar futuras contradições.

\footnotetext{
${ }^{134}$ Yochai Benkler, "A Free Irresponsible Press: Wikileaks and the Battle over the Soul of The Networked Fourth State", p. 38.

${ }^{135}$ Recurso Extraordinário no 511.961; julgamento em 17.11.2009, relator ministro Gilmar Mendes. O resultado foi por maioria de votos, vencido o ministro Marco Aurélio de Melo. O recurso decorre de uma ação civil pública proposta pelo Ministério Público Federal em primeira instância, em São PauloSP.
} 
Logo, não se pretende aqui conceder algum peso determinante à decisão do recurso extraordinário n. 511.911 - mas, tampouco, deixar de considerá-lo como um importante marco na concepção jurídica da liberdade de imprensa no país, conforme razões expostas a seguir.

A rigor, entender como inconstitucional a exigência de diploma para o exercício do jornalismo não é fator determinante para a adoção de um dos caminhos do debate entre as abordagens institucional e funcional. Nos Estados Unidos, por exemplo, a inexigência de diploma é uma constante histórica e, ainda assim, como visto anteriormente neste capítulo, subsiste um debate vigoroso naquele país. Ainda assim, o argumento pela inexigência do diploma é uma razão freqüentemente invocada por autores para sustentar a não possibilidade de distinção entre imprensa e cidadãos em geral naquele país.

Há uma razão para isso: em resumo, duas leituras distintas podem emergir a partir da oposição de concepções sobre quais direitos fundamentais são tratados e afetados pela decisão de se proibir a exigência de diploma para o exercício do jornalismo.

Por um lado, é possível compreender que a decisão diz respeito tão somente à liberdade profissional dos cidadãos. Segundo essa linha de raciocínio, a decisão não implica uma confusão de jornalistas profissionais com cidadãos em geral, pois apenas derruba um requisito jurídico e formal para que uma pessoa se integre àquela primeira categoria. A decisão do STF, assim, não guardaria diferenças em comparação à declaração de invalidade de requisitos para o exercício das profissões de policial, corretor de imóveis ou engenheiro, por exemplo.

Parece, contudo, que limitar uma análise sobre a questão apenas à liberdade profissional significa desconsiderar os argumentos mais relevantes que estão envolvidos. Ao contrário do que ocorre com restrições a outras profissões, como aquelas mencionadas acima, uma discussão sobre a obrigatoriedade do diploma de jornalismo implica diretamente uma discussão sobre o fluxo livre de informações em uma sociedade - tanto em seu aspecto quantitativo (mais pessoas podem exercer a 
função), quanto em seu aspecto qualitativo (haverá uma pluralidade maior de formações e pontos de vista incluídos no debate).

A motivação da decisão do STF expõe de modo bastante claro esse viés. Embora a liberdade profissional tenha sido um dos direitos fundamentais envolvidos no debate, a decisão claramente apoiou-se em razões materiais ligadas aos temas da liberdade de imprensa e de expressão.

Inicialmente, o voto do ministro relator Gilmar Mendes começa sua argumentação a partir da liberdade profissional (inciso XIII, do art. $5^{\circ}$ da CF), concluindo, em resumo, que a atividade do jornalismo não implica riscos inerentes de danos efetivos a terceiros, razão pela qual entende ser desproporcional que o Estado exija um diploma para seu exercício.

Logo em seguida, porém, a decisão passa a tecer considerações sobre como "não se trata apenas de verificar a adequação de uma condição restritiva para o exercício da profissão, mas de constatar que, num âmbito da livre expressão, o estabelecimento de qualificações profissionais é terminantemente proibido pela ordem constitucional".

E ainda: "o ponto crucial é que o jornalismo é uma profissão diferenciada por sua estreita vinculação ao pleno exercício das liberdades de expressão e informação. O jornalismo é a própria manifestação e difusão do pensamento e da informação de forma contínua, profissional e remunerada. Os jornalistas são aquelas pessoas que se dedicam profissionalmente ao exercício pleno da liberdade de expressão. O jornalismo e a liberdade de expressão, portanto, são atividades que estão imbricadas por sua própria natureza e não podem ser pensadas e tratadas de forma separada".

Por isso, conclui, a interpretação da liberdade profissional deve ser feita "impreterivelmente" em conjunto com "os preceitos do art. $5^{\circ}$, incisos IV, IX XIV, e do art. 220 da Constituição, que asseguram as liberdades de expressão, de informação e de comunicação em geral". 
Aproximando-se da tradição norte-americana, a decisão comenta que a proibição da obrigatoriedade da exigência de diploma é um corolário da proibição de censura prévia: “a exigência de diploma do curso superior para a prática do jornalismo - o qual, em sua essência, é o desenvolvimento profissional das liberdades de expressão e de informação - não está autorizada pela ordem constitucional, um impedimento, uma verdadeira supressão do pleno, incondicionado e efetivo exercício da liberdade jornalística, expressamente proibido pelo art. 220, parágrafo primeiro, da Constituição" ${ }^{136}$. Outras passagens reiteram o conceito de jornalismo como "umbilicalmente ligado às liberdades de expressão e de informação".

A decisão do STF invocou também um relevante precedente da Corte Interamericana de Direitos Humanos que, por meio de sua jurisdição consultiva, quando em análise de legislação da Costa Rica, já havia concluído, em sentido equivalente, que a obrigatoriedade de diploma universitário e de inscrição profissional para jornalistas é incompatível com o art. 13 da Convenção Americana de Direitos Humanos, referente à liberdade de expressão. Segundo a decisão, “o jornalismo é a manifestação primária e principal da liberdade de expressão do pensamento e, por essa razão, não pode ser meramente concebido como a prestação de conhecimento ou capacitação adquirida em uma universidade ou por quem está inscrito em um determinado órgão profissional - como poderia ocorrer com outras profissões - pois está vinculado à liberdade de expressão que é inerente a todo ser humano" ${ }^{137}$.

Ao adotar esses argumentos, a decisão do STF incorporou o cerne da racionalidade que justifica uma abordagem de "imprensa aberta" ("open press"), qual seja: caracterizar o jornalismo - ou a liberdade de informação - como uma atividade intimamente ligada à liberdade de expressão dos indivíduos. Realça-se sua dimensão opinativa, valorativa e ligada ao autogoverno, em oposição à caracterização de uma atividade técnica e objetiva. Em suma, são as razões que justificam uma séria desconfiança quanto à diferenciação entre cidadãos e jornalistas pelo Estado.

\footnotetext{
${ }^{136}$ Em outro trecho, a decisão menciona expressamente que a exigência de diploma configura "controle prévio que, em verdade, caracteriza censura prévia das liberdades de expressão e de informação, expressamente vedada pelo art. $5^{\circ}$, inciso IX, da Constituição".

${ }^{137}$ Corte Interamericana de Direitos Humanos, Opinião Consultiva ${ }^{\circ}$ 05, de 13 de novembro de 1985.
} 
É razoável avaliar que, ao incorporar esses argumentos, os ministros do STF não necessariamente quiseram levá-los até suas últimas conseqüências - até porque certamente, durante o julgamento daquele recurso extraordinário, o tema proposto por este trabalho não era algo que preocupava o tribunal. Mas, a rigor, a decisão justificase pelos fundamentos principais de um modelo de "imprensa aberta".

Ainda sob essa perspectiva, a decisão possui especial relevância porque é um marco que rompe com uma tradição jurídica - e social - que aceitava com certa naturalidade a formalização e categorização da imprensa profissional, através da concessão pelo Estado de diploma de jornalismo, sem maiores problematizações.

\section{4.e - Análise crítica sobre o debate}

Naturalmente, o debate apresentado neste capítulo quanto à oposição das abordagens institucional e funcional à liberdade de imprensa é em grande parte peculiar ao direito e ao contexto norte-americano.

Como visto, essa discussão intensificou-se naquele país a partir do momento em que jornalistas profissionais passaram a defender que a proteção à imprensa garantida pela Primeira Emenda implicava também o direito de sigilo de fonte. A estratégia de constitucionalização dessa prerrogativa nos tribunais desenrolou-se em um país que conta com um texto constitucional bastante sintético e que, quando reconhece tal status a um direito, coloca-o em posição extremamente privilegiada quando confrontado com interesses contrários. Esse reclamo, em especial, é descabido no Brasil, país no qual o texto constitucional - bastante extenso e amplo em seu caráter normativo - garante expressamente o sigilo de fonte aos profissionais.

De qualquer modo, a oposição entre as abordagens institucional e funcional à liberdade de imprensa mantém-se como pano de fundo de uma questão essencial: faz sentido o Estado categorizar as pessoas com a finalidade de lhes conceder mais ou menos recursos jurídicos para o exercício da liberdade de informação? 
Parece que a resposta para essa pergunta necessita de alguns elementos que estão além dos textos normativos ${ }^{138}$. Como ocorre em outros problemas jurídicos complexos, é necessário reconhecer que a própria interpretação sobre o direito positivo é condicionada por uma - declarada ou não - compreensão mais ampla que envolve o papel do Estado, suas características e seus limites em suas relações com os cidadãos, além de além de concepções, divergências e debates sobre o conteúdo de direitos fundamentais ${ }^{139}$. Por isso, para responder àquela indagação, torna-se necessário assumir e defender alguns fundamentos - o que se buscará fazer neste item, de modo a esclarecer algumas posições e compreensões do autor do trabalho.

As dificuldades que decorrem da abordagem institucional são evidentes. De um ponto de vista democrático, a abordagem institucional baseia-se na ideia de uma elite auto-eleita que argumenta representar o interesse público, mas de acordo com suas próprias normas e parâmetros corporativos.

Naturalmente, isso gera uma limitação não apenas aos pontos de vista que irão compor o debate público, mas também aos próprios temas e assuntos que estarão em sua pauta: a imprensa profissional foca sua atenção a problemas que atingem uma parcela ampla da população - ampla, ao menos, na mesma extensão dos consumidores que formam seu público-alvo. Como conseqüência, diversos fatos ou assuntos deixam de justificar uma cobertura jornalística - seja porque são muito peculiares a determinada comunidade ou localidade, ou porque dizem respeito apenas a um grupo, ainda que amplo, que não compõe o público-alvo de nenhuma publicação.

Por que não reconhecer igual importância jurídica ao livre fluxo de informações em comunidades mais restritas - como bairros ou ambientes

\footnotetext{
${ }^{138}$ No caso brasileiro, a proteção à "liberdade de informação jornalística" é prevista pelo art. $220, \S 1^{\circ}$, da Constituição. O texto constitucional também menciona o direito fundamental à "comunicação" (art. $5^{\text {a }}$, inciso IX), de "acesso à informação" (art. $5^{\circ}$, inciso XIV) e de "informação" (art. 220, caput). O termo "liberdade de imprensa" é utilizado marginalmente em dispositivo sobre o estado de sítio (art. $139)$.

${ }^{139} \mathrm{O}$ Estado pode diferenciar o reconhecimento de relações afetivas com base em orientações sexuais (eventual direito à igualdade)? O Estado deve tolerar o discurso do ódio na sociedade - e, se sim, até que ponto (eventual liberdade de expressão)? O Estado pode criminalizar ou impor condutas com relação ao consumo de drogas ou a práticas abortivas (eventual direito à liberdade)? São questões cujas respostas jurídicas também defendem necessariamente determinados parâmetros de relação entre o Estado e tais direitos fundamentais, façam isso abertamente ou não.
} 
universitários, por exemplo - que obviamente não costumam despertar interesse de jornalistas profissionais, mas podem constituir um universo tratado por publicações locais, ainda que amadoras ou sem interesse de lucro?

Ainda nesse sentido, uma visão institucional de imprensa limita em um nível jurídico - chancelado pelo Estado - quais interesses terão papéis predominantes para o fluxo de informações socialmente relevantes. Essa limitação torna-se injustificada se aceitarmos a premissa de que essas informações não surgem ao público espontaneamente; ao contrário, elas são detidas por inúmeros atores sociais, com interesses vários e distintos, que por alguma razão em particular decidem divulgá-las.

No limite, a abordagem institucional baseia-se na seguinte concepção: "o que é essencial não é que todo mundo fale, mas sim que tudo o que valha a pena ser dito seja dito" ${ }^{140}$ - o que, claro, levanta dúvidas sobre o que vale a pena ser dito e quem decide isso.

No mais, ao se basear em uma definição prévia e obscura sobre o que é ou não é protegido pela liberdade de imprensa - em regra, com o objetivo declarado de afastar a universalização desse direito -, essa abordagem desconsidera de antemão condutas que estão relacionadas com esse direito constitucional e desvincula-se do encargo de fornecer argumentos para negar proteção constitucional àqueles que a invocam. Nesse sentido, parece adotar a defesa de um suporte fático restrito para esse direito fundamental e torna-se uma concepção bastante problemática de se sustentar

\footnotetext{
${ }^{140}$ Alexander Meiklejohn, Political Freedom: The constitutional powers of the people. Westport, Connecticut: Greenwood Press, 1979, p. 26. A frase é notória no debate norte-americano sobre liberdade de expressão. Meiklejohn escreveu essa influente obra para fazer uma contundente defesa de um caráter "absoluto" da liberdade de expressão, apresentada como corolário do auto-governo de cidadãos em uma democracia, ainda em uma época de perseguição a opiniões políticas de esquerda no início da Guerra Fria (o texto original é de 1948). A frase citada insere-se em passagem na qual o autor defende ser necessário que o Estado regule o debate entre cidadãos: “A Primeira Emenda, portanto, não é a guardiã da falação desordenada. Ela não requer que, em todas as ocasiões, todos os cidadãos tomem parte no debate público. Nem assegura que todos terão essa oportunidade. Se por exemplo, em uma audiência pública ('town meeting'), vinte cidadãos que pensem de modo semelhante se tornarem um 'partido', e se um deles ler aos demais presentes os argumentos com os quais todos de seu grupo concordaram, seria ridículo permitir que cada um deles insistisse em repeti-los. Nenhum moderador competente poderia tolerar essa perda de tempo em uma discussão livre. O que é essencial não é que todo mundo fale, mas sim que tudo o que valha a pena ser dito seja dito".
} 
se for adotada como procedente a premissa de que direitos fundamentais são princípios jurídicos, concebidos como mandamentos de otimização ${ }^{141}$.

\section{4.e.i. - Relevância jurídica versus relevância de fato}

Parece ser mais apropriado defender a premissa de uma titularidade difusa para o exercício da liberdade de informação, o que garante, ao menos em um nível jurídico, um ponto de partida igualitário para o desempenho dos atores no "marketplace" de ideias e informações.

A ressalva de "ao menos em um nível jurídico" não é à toa. Uma discussão no nível de argumentos constitucionais necessariamente trata apenas do potencial exercício de um direito fundamental. Com isso se quer ressaltar que uma concepção ampla da titularidade da liberdade de imprensa ou de informação não significa uma percepção ingênua de que a imprensa profisssional não possui ou passa a perder seu papel proeminente na formação da opinião pública. Um cidadão munido de um blog certamente não terá o mesmo poder de fato do que um jornal consagrado, obviamente.

Se opinar na internet é barato quase ao ponto de um "custo zero", esse não é o caso da produção de reportagens investigativas sólidas. Há razões pelas quais os veículos profissionais são capazes de fazê-las: um repórter experiente deve dedicar bastante tempo e recursos durante sua apuração - como viagens, entrevistas, análise de documentos -, quase sempre sem garantia de que sua pista inicial irá terminar com um texto publicável. Em resumo: fazer jornalismo é caro, e em regra apenas uma estrutura corporativa e profissional possui as condições de fazê-lo. Mas reconhecer que essa seja a regra geral não desmerece o argumento de que, eventualmente, um autor solitário de um livro-reportagem ou de um documentário não deva ser visto como detentor de iguais direitos e prerrogativas.

Essa diferença de "relevância de fato" possui também implicações simbólicas. É natural imaginar que uma ordem judicial de busca e apreensão que deva ser cumprida na redação de um jornal consagrado - para eventual superação do sigilo de

\footnotetext{
${ }^{141}$ Conforme conceitos apresentados na apresentação dos pressupostos teóricos deste trabalho, em sua introdução.
} 
fonte, por exemplo - cause sérias resistências com fundamento na defesa da liberdade de imprensa. Pode-se até dizer que dificilmente um juiz emitiria tal ordem, assim como é excepcional uma ordem similar ser determinada nas dependências de um escritório de advocacia.

Muito mais natural é imaginar uma ordem de busca e apreensão a ser cumprida na residência de um autor ou de um blogueiro, que não conta com a dimensão simbólica da imprensa institucional. E ainda que essa ordem judicial busque confiscar material relativo a alguma publicação, há uma dificuldade natural em imaginar que ela possa ser contestada como uma ofensa à liberdade de informação - o próprio local seria uma residência, e não uma redação jornalística reconhecida. Essa estranheza, no entanto, não merece prosperar: se a liberdade de imprensa é concebida como uma atividade ou função, não haveria razões para desmerecer uma defesa feita sob esse direito constitucional, tanto como naquele outro caso ${ }^{142}$.

\section{4.e.ii- Jornalismo como atividade}

Faz mais sentido, portanto, compreender a imprensa ou o jornalismo como uma atividade. Esse pressuposto é coerente com o conceito de que a proteção constitucional à imprensa relaciona-se não a um conjunto de atores ou a uma corporação, mas sim à importância de uma atividade que promove o livre fluxo de informações socialmente relevantes.

A adoção de uma abordagem funcional à liberdade de imprensa, entretanto, não supera os problemas relacionados ao seu significado - ela apenas os desloca. "A questão é se definir a imprensa como função jornalística é menos problemático do que

\footnotetext{
${ }^{142}$ Nos Estados Unidos, coerente com sua postura de não diferenciar os jornalistas de cidadãos comuns, a Suprema Corte decidiu em Zurcher v. Stanford Daily (1978) que não havia qualquer proteção constitucional que criasse obstáculo a buscas e apreensões em redações de jornais. Naquele caso, uma ordem havia sido emitida contra o jornal estudantil da Universidade de Stanford, porque a polícia suspeitava que seus jornalistas estivessem em posse de fotografias feitas em um protesto no centro médico local, dias antes. Desde então, tanto na esfera federal quanto estadual, leis criaram regras que restringem bastante a possibilidade de decisões nesse sentido, prevendo exceções no caso de repórteres suspeitos de crimes ou em casos de ameaça a vidas - David Anderson, "Freedom of The Press in Wartime”, p. 67; Anthony Lewis, “A Preferred position for journalism?”, p. 607.
} 
defini-la pelas formas de mídia" ${ }^{143}$. Em outras palavras: "o que é notícia e o que é jornalismo?" 144 .

As novas perguntas que surgem a partir de uma abordagem funcional não podem ser consideradas pouco complicadas. Se tomarmos como ponto de partida o conceito de que jornalismo diz respeito às informações de interesse público, por exemplo, devemos nos perguntar: o que é um assunto de interesse público? Apenas temas sobre instituições públicas oficiais? Nesse caso, há interesse público na cobertura de empresas, atores econômicos privados ou instituições financeiras? Reportagens sobre moda, consumo e cultura possuem importância política ou de interesse público? E como aplicarmos esses critérios a conteúdos que transitam entre os campos da informação e do entretenimento?

Para Anderson, “o que está em jogo, é claro, é se acreditamos que alguns tipos de informações são mais importantes do que outras, e se estamos preparados para deixar algum poder governamental decidir o que é importante" ${ }^{145}$. A discussão, portanto, necessariamente chega a um ponto no qual é necessário discutir o que é jornalismo, o que o torna mais valoroso do que outros tipos de informação e quais são os critérios necessários para identificá-lo.

Aqui, novamente, o conceito de direitos fundamentais como princípios jurídicos fornece algumas diretrizes relevantes. Talvez o maior risco para esse debate seja uma tentativa de se definir previamente critérios jurídicos para se diferenciar o que é jornalismo legítimo - ou, em outras palavras, liberdade de informação constitucionalmente protegida. Nesse caso, a delineação de "limites imanentes" ou algo próximo a isso provocaria críticas análogas às feitas acima com relação a uma abordagem institucional.

\footnotetext{
${ }^{143}$ David Anderson, "Freedom Of The Press", p. 446. O autor continua: "Se 'imprensa' significa jornalismo, as proteções constitucionais especiais que emanam da Press Clause (se é que elas existem), extenderiam-se apenas para quaisquer atividades que sejam contempladas pelo termo 'jornalismo', e o resto das atividades da mídia receberia proteção apenas da Speech Clause. Benefícios não constitucionais (como subsídios, facilidades de acesso, entre outros privilégios) iriam para aqueles que convencessem os legisladores e outras autoridade que eles os merecem, mas essas autoridades presumivelmente iriam favorecer os candidatos engajados na atividade de jornalismo pelas mesmas razões que eles atualmente favorecem certas formas de mídia".

${ }^{144}$ David Anderson, "Freedom Of The Press", p. 445.

${ }^{145}$ David Anderson, "Freedom Of The Press", p. 435.
} 
Compreender a liberdade de informação à luz da teoria dos princípios - ou seja, como mandados de otimização - contribui para transferir o foco de uma tentativa de definição prévia de situações juridicamente protegidas para uma ênfase na necessidade de se justificar as eventuais restrições jurídicas impostas ${ }^{146}$. Em outras palavras: devemos considerar como protegidas a priori pela liberdade constitucional de informação todas as condutas que sejam relacionadas com o âmbito temático desse direito. Como já apontado no capítulo 1, isso não quer dizer que esse direito fundamental irá determinar o resultado final de um problema jurídico, já que isso dependerá das circunstâncias fáticas e jurídicas de um caso. Mas reforça-se que não há uma necessidade de se partir de um conceito estanque ou definido de jornalismo legítimo ou de "informação constitucionalmenteo protegida" em caráter definitivo.

É incontroverso que a proteção constitucional à imprensa (compreendida como atividade ou função) justifica-se pelo livre fluxo de informações de interesse público. "Interesse público" é um termo praticamente impossível de se definir, pois em regra analisa-se qual é o interesse público em uma determinada situação, sob múltiplos enfoques. Exatamente por isso, se compreendermos esse direito fundamental como um mandamento de otimização, é possível considerar que quanto mais robusto for o interesse público contido na disseminação de informações, mais contundente terá que ser a motivação de uma eventual restrição sobre essa liberdade.

Não se trata apenas de um jogo de palavras: isso garante que não se exclua previamente a proteção constitucional da liberdade de informação jornalística a relatos feitos, por exemplo, sobre pessoas que não ocupam cargos públicos, sobre assuntos empresariais internos ou outros assuntos de temas que não são costumeiramente ligados às razões que justificam uma proteção ao jornalismo. Tampouco se exclui dessa proteção os relatos feitos por livros, documentários, pesquisas acadêmicas ou blogs, por exemplo.

\footnotetext{
${ }^{146}$ A esse respeito: Virgílio Afonso da Silva, Direitos Fundamentais: conteúdo essencial, restrições e eficácia, pp. 130 e ss.
} 
Ainda assim, após essas considerações, é necessário ressaltar alguns aspectos que caracterizam o âmbito temático da proteção constitucional à imprensa, compreendida como função. Isso porque não faz sentido igualar esse direito fundamental com qualquer tipo de divulgação de informações ou de dados. Um serviço de previsão metereológica ou uma enciclopédia, a rigor, também disseminam informações ao público - mas claramente não são compreendidos como jornalismo por algumas razões. A seguir, serão elencados alguns aspectos que nos parecem cruciais para compreender o que constitui essa atividade em especial.

\section{4.e.iii - Julgamento editorial e objetividade jornalística}

Randall Bezanson parece ter razão ao dizer que o "julgamento editorial" constitui a ideia central de proteção constitucional à liberdade de imprensa, que ele caracteriza como a "atividade que reflete uma escolha independente de informações e opiniões atualmente relevantes, direcionada ao interesse público e motivada por propósitos que não sejam interesses próprios" ${ }^{147}$. Note-se que esse conceito é plenamente aplicável, sob uma compreensão funcional da liberdade de imprensa, a divulgações de informações que não são tradicionalmente consideradas jornalismo como documentários, livros, pesquisas acadêmicas, e etc.

Além de apontar os evidentes elementos de coletas de informações destinadas ao público, essa definição é especialmente interessante pelo seguinte motivo: ela reconhece que a liberdade de imprensa relaciona-se à pretensão de um relato fático $\mathrm{e}$ verídico, mas não adota esse aspecto como uma característica total. Ou seja: a seleção de fatos e os recortes operados durante a narrativa são resultados de um processo editorial que, no limite, é opinativo. A hierarquização de notícias, os termos utilizados, o espaço que é destinado a cada texto, entre outros fatores, são resultados que, embora muitas vezes pautadas por parâmetros profissionais consagrados, não deixam de resultar de vieses valorativos. Não é por outro motivo que um "mesmo fato" pode merecer coberturas tão diversas de diferentes veículos ou repórteres. Essa

\footnotetext{
${ }^{147}$ Randall Bezanson, “The Developing Law of Editorial Judgment”, Nebraska Law Review 78 (1999), pp. 857 e ss. Para ele, "a imprensa não pode ser bem descrita em termos insitucionais. Seus produtos não podem ser facilmente distinguidos apenas pelo conteúdo. Nenhum conjunto de procedimentos ou referëncias, compreendidos de modo estrito, podem adequadamente capturar a ideia específica mas generosa de imprensa livre”. Para uma crítica sobre esse posicionamento, ver: David Anderson, "Freedom Of The Press", pp. 452 e ss.
} 
dimensão - crítica, opinativa, comumente associada à liberdade de expressão - é inescapável.

Essa definição parece se opor a um argumento muito comum de obras jurídicas brasileiras sobre "liberdade de imprensa" ou "liberdade de informação", que costumam relacioná-las a relatos puramente objetivos sobre fatos, plenamente diferenciáveis de manifestações subjetivas do pensamento humano. Nesse sentido, por exemplo: Luís Roberto Barroso ${ }^{148}$, Luis Gustavo Gradinetti Castanho de Carvalho ${ }^{149}$ e Vidal Serrano Nunes Júnior ${ }^{150}$.

Os posicionamentos desses autores parecem presumir um conceito forte demais de objetividade jornalística, que diferencia de modo absoluto os relatos de fatos, por um lado, de manifestações de opiniões, por outro. É verdade que determinadas afirmações - a depender de suas pretensões - podem ser confirmadas ou desmentidas. É possível, por exemplo, dizer que uma cadeira não é igual a um cachorro. Mas dificilmente textos narrativos podem se arvorar sobre uma pretensão de serem puramente objetivos. Eles podem se permitir mais ou menos impressões

\footnotetext{
148 "A doutrina brasileira distingue as liberdades de informação e de expressão, registrando que a primeira diz respeito ao direito individual de comunicar livremente fatos e ao direito difuso de ser deles informado; a liberdade de expressão, por seu turno, destina-se a tutelar o direito de externar idéias, opiniões, juízos de valor, em suma, qualquer manifestação do pensamento humano" (Luís Roberto Barroso, "Liberdade de expressão versus direitos da personalidade. Colisão de direitos fundamentais e critérios de ponderação", Temas de direito constitucional: Tomo III. Rio de Janeiro: Renovar, 2 ed., 2005, p. 103).

${ }^{149} \mathrm{O}$ autor chega a propor um "direito difuso à informação verdadeira", que poderia ensejar o ajuizamento de ações judiciais de tutela coletiva para compelir "órgãos de comunicação" a publicar um "informe verdadeiro", a ser "descoberto" ou "demonstrado" no âmbito de um processo judicial. Segundo Carvalho, "tão grave quanto deturpar é dar a opinião ou a propaganda como notícia" (p. 101). E ainda: "uma vez optando o órgão da imprensa pela publicação da matéria jornalística, surge para o leitor um direito: o direito à informação verdadeira" (p. 91); "concretamente apresenta-se cabível a ação civil pública para postular do Poder Judiciário a inserção compulsória de notícia verdadeira, sempre que se demonstre que a informação dada pelo órgão da imprensa não tenha sido exata, independentemente da alegação de prejuízo moral ou patrimonial" (p. 114) - Luis Gustavo Grandinetti Castanho de Carvalho, Liberdade de Informação e o Direito Difuso à Informação Verdadeira. Rio de Janeiro: Renovar, 2 ed., 2003.

150 "O que se afirma, portanto, é que a notícia, quando veiculada sem agregação da crítica, é isenta de valores. Dessa maneira, ao seu emissor nunca se poderá imputar comportamento calunioso ou injurioso, posto que este pressupõe juízo de desvalor da vítima (que, mesmo em tese, só seria possível em eventual abuso do direito de crítica) " - Vidal Serrano Nunes Júnior, Direito e Jornalismo. São Paulo: Verbatim, 2011, p. 55.
} 
opinativas, mas no limite expressam recortes, pré-julgamentos e escolhas de termos ${ }^{151}$ que revelam vieses valorativos, decorrentes da liberdade editorial ${ }^{152}$.

Nesse sentido, a definição do verbete objetividade pelo Manual de Redação do jornal Folha de S. Paulo: "não existe objetividade em jornalismo. Ao escolher um assunto, redigir um texto e editá-lo, o jornalista toma decisões em larga medida subjetivas, influenciadas por suas posições pessoais, hábitos e emoções. Isso não o exime, porém, da obrigação de ser o mais objetivo possível”"153.

A divergência não é desprezível: como visto no capítulo anterior, a defesa de características técnicas e objetivas do jornalismo facilita uma diferenciação jurídica dessa atividade nos termos propostos pelo modelo de "imprensa livre". Em contrapartida, o reconhecimento de algum grau opinativo ou valorativo implica uma aproximação ao modelo de "imprensa aberta".

\section{4.e.iv- Independência ou isenção jornalística?}

Outro aspecto frequentemente discutido em associação ao jornalismo é a questão da "independência" ou "isenção" do veículo. Seriam requisitos ou características necessárias à atividade jornalística?

Para David Anderson, a independência ainda é mencionada como uma premissa crucial ao jornalismo. Ainda assim, "ninguém espera que o jornalista opere independentemente de quaisquer limitações, obedecendo apenas à sua própria crença jornalística. Em sua maior parte, jornalistas cobrem aquilo que os editores lhes mandam cobrir e cedem às suas decisões sobre o que será publicado ou transmitido". Repórteres e editores, por outro lado, entendem que há limitações decorrentes do controle proprietário - inclusive em casos de cobertura da vida pessoal do publisher, seus negócios ou processos que o envolvam, por exemplo ${ }^{154}$.

\footnotetext{
${ }^{151}$ O grupo de sem-teto promove uma "invasão" ou uma "ocupação" de propriedade privada? Uma ação armada é "revolucionária" ou "terrorista"? Um chefe de Estado é "presidente" ou "ditador"?

${ }^{152}$ Para um debate constitucional sobre a objetividade jornalística, à luz de um precedente da Suprema Corte norte-americana, ver: Kathy Roberts Forde, Literary Journalism on Trial - Masson v. New Yorker and the First Amendment. Amherst: University of Massachusetts Press, 2008.

${ }^{153}$ Folha de S. Paulo: Manual de Redação. São Paulo: Publifolha, 8a ed., 2001.

${ }^{154}$ David Anderson, "Freedom Of The Press ", p. 453.
} 
Para problematizar essa questão, Anderson tece considerações sobre como as mudanças do modelo econômico do jornalismo interferem diretamente sobre ela. Ao longo do século $\mathrm{XX}$, a maior parte dos veículos de imprensa eram propriedades familiares. Sob esse cenário, decisões judiciais - inclusive da Suprema Corte reconheciam que as empresas de mídia diferenciavam-se significativamente de outras em razão de seu objetivo social de coleta e disseminação de informações ao público.

Contudo, desde os anos 1990, muitas empresas deixaram de ser controladas por famílias, após serem compradas por grandes conglomerados econômicos, inclusive de capital aberto ${ }^{155}$. O próprio jornalismo, portanto, passa a ser exercido no interior de grupos com diversos - e por vezes muitos mais economicamente relevantes - outros interesses. Isso causa uma série de consequências: "controle financeiro imposto pela empresa-mãe determina mudanças no tamanho e qualidade da equipe editorial, de conteúdo, prioridades de cobertura, segmentação de marketing", além de "focar em decisões de curto prazo e limitar a habilidade dos jornais de investir em um noticiário original e uma relação de longo prazo com seus leitores"156.

Anderson fornece uma interessante indagação: "periódicos publicados por associações privadas ou grupos de lobby" não recebem credenciais de imprensa no Congresso em função de seus interesses privados. "Por que os jornalistas da $\mathrm{ABC}$, NBC e CBS são diferentes? Nós devemos aceitar suas palavras de que eles não irão utilizar suas prerrogativas de imprensa para promover outros interesses de seus proprietários? Em caso positivo, porque não aceitamos garantias semelhantes de quem escreve para a ‘Consumer Reports'ou 'Petroleum News'?’ 157.

De um modo geral, Anderson busca reafirmar a concepção de que o jornalismo pressupõe um nível de independência e de busca do interesse público acima de interesses empresariais próprios. Ainda assim, aponta que "se o novo padrão de controle de empresas irá ou não distorcer os julgamentos jornalísticos, eles ao

\footnotetext{
${ }^{155}$ David Anderson, "Freedom Of The Press", p. 455. Alguns exemplos: a General Eletric é proprietária da NBC, a Walt Disney Co. é dona da ABC, a Viacom Inc. controla a CBS, etc.

${ }^{156}$ David Anderson, "Freedom Of The Press", p. 458.

${ }^{157}$ David Anderson, "Freedom Of The Press", p. 456.
} 
menos requerem a reconsideração da ideia de que os proprietários da imprensa são diferentes de proprietários de outros negócios" ${ }^{158}$.

A questão da "isenção" também é abordada pela análise de Benkler sobre o Wikileaks. O autor busca refutar o argumento de que aquele website não produz “jornalismo legítimo" porque teria o propósito declarado - e de certo modo militante - de dificultar o funcionamento de governos, fragilizando suas redes de comunicação entre órgãos internos através da exposição de segredos constrangedores. Segundo a "ideologia" declarada do Wikileaks, isso minaria os poderes do Estado e, por consequência, sua capacidade de oprimir os cidadãos. Benkler considera que "o propósito de se proteger a imprensa é sistêmico e funcional - e serve para obter um público mais esclarecido, o que é uma pré-condição para uma democracia que funcione bem. A motivação que leva qualquer indivíduo a esse objetivo é completamente irrelevante à questão essencial. (...) Um repórter que opera por suas convicções políticas é tão protegido quanto um repórter que quer apenas ganhar dinheiro, virar uma celebridade ou humildemente servir ao interesse público" ${ }^{159}$.

Não há dúvidas de que é possível avaliar o desempenho de um determinado veículo de imprensa tomando por base comparativa uma "isenção" desejada ou possível - isso poderia, inclusive, ser feito através dos melhores critérios consagrados pelo jornalismo profissional. A credibilidade de um veículo é um dos componentes relevantes que constróem seu grau de influência sobre a opinião pública. No limite, contudo, até mesmo essa isenção possível é circunstancial: pode depender de momentos, de assuntos ou até de acertos ou erros de julgamento editorial.

No mais, reconhecer um desempenho ideal como virtude não significa tomá-lo como condição para caracterizar ou reconhecer uma atividade. Se a ideia de objetividade jornalística pura (compreendida como mero relato factual objetivo) não é crível, Benkler tem razão ao apontar que tampouco a imparcialidade é condição necessária para que uma atividade informativa mereça proteção constitucional.

\footnotetext{
${ }^{158}$ David Anderson, "Freedom Of The Press", p. 460.

${ }^{159}$ Yochai Benkler, "A Free Irresponsible Press: Wikileaks and the Battle over the Soul of The Networked Fourth State”, p. 41. O autor complementa: “a Fox News não seria menos merecedora da liberdade de imprensa se fossem achados vários memorandos internos que revelassem que seu objetivo principal é minar a capacidade do presidente Obama de governar, mais do que informar o público".
} 
Se a proteção constitucional à imprensa demanda algum tipo de "independência", trata-se da independência da liberdade editorial com relação ao Estado (uma verdadeira liberdade intelectual, ou de expressão) - e não uma "isenção" do discurso ou relatos de pessoas, profissionais e empresas que se engajam em uma atividade informativa.

\section{4.f. Considerações finais do capítulo}

Este capítulo buscou apresentar de modo detido os argumentos que caracterizam as abordagens institucional e funcional à liberdade de imprensa, a partir do debate travado no direito norte-americano. Buscou-se também assumir e defender alguns fundamentos em uma perspectiva crítica, que se revelou favorável à abordagem funcional.

De qualquer modo, a rigor, discutir se uma atividade é informativa e jornalística não se confunde com discutir se ela faz jus à prerrogativa do sigilo de fonte.

Diferentes sistemas jurídicos podem ou não reconhecer a existência dessa prerrogativa - e isso dependerá das próprias regras jurídicas que compõem esse sistema, normalmente criadas por decisões do legislativo. É possível vislumbrar uma atividade suis generis que exerça um papel jornalístico para a sociedade, mas que não atinge todos os critérios jurídicos elencados por uma regra para utilização do privilégio do sigilo de fonte. Nos Estados Unidos, por exemplo, as chamadas shield laws existem apenas em âmbitos estaduais e disciplinam a questão de modo diverso para cada território.

Essa distinção de problemas, no entanto, é praticamente relevada se for considerada inconstitucional uma eventual restrição imposta pela legislação, a partir de uma concepção funcional da liberdade de imprensa. Esse aspecto será analisado à luz do direito brasileiro no capítulo 5, a seguir. 


\section{Capítulo 5 - O sigilo de fontes jornalísticas}

A proteção ao sigilo de fonte não é a única prerrogativa da qual se valem os jornalistas no exercício de suas atividades. Repórteres tradicionalmente possuem facilidades de acesso às informações que não costumam ser franqueadas ao público em geral. Essa distinção às vezes possui base em alguma regra legal ou administrativa, mas muitas vezes decorre apenas de práticas e costumes consagrados.

O poder público, por exemplo, não apenas fornece credenciais que garantem acesso exclusivo ou privilegiado a eventos, entrevistas coletivas, reuniões e afins, mas também custeia salas de imprensa em suas dependências, para garantir espaços e equipamentos a jornalistas. Equipes de assessoria de imprensa são mantidas para atender aos pedidos dos profissionais, feitos nas mais variadas formas possíveis. É razoável dizer, por exemplo, que um jornalista possui mais chances de obter informações de autoridades policiais do que um cidadão que se dirige a uma delegacia, ainda que a maior parte das investigações seja pública ${ }^{160}$.

Ainda assim, a proteção ao sigilo de fonte certamente é o caso mais extremo e controverso - entre as prerrogativas dos jornalistas, pelos motivos que serão desenvolvidos a seguir.

A racionalidade do sigilo de fonte é bastante direta: sem receber uma garantia de anonimato por parte de jornalistas, muitas fontes deixariam de transmitir informações diante dos riscos a que estariam submetidas - fossem de ordem pessoal, profissional, de responsabilização jurídica ou afins. Argumenta-se que, sem esse mecanismo, a imprensa não poderia desenvolver a contento seu papel na sociedade, especialmente com relação aos casos de exposição de corrupção, ilegalidades, segredos oficiais e outros ${ }^{161}$.

\footnotetext{
${ }^{160}$ A lei federal $\mathrm{n}^{\mathrm{o}} 12.527 / 2001$ - conhecida por Lei de Acesso à Informação - pretende, de certo modo, superar a dificuldade de qualquer cidadão de obter informações públicas.

${ }^{161}$ Nas palavras de Alexander Bickel, em parecer oferecido à Suprema Corte americana, quando do julgamento do caso Branzburg v. Hayes: “(...) não há sequer um paradoxo superficial na proposição de que para resguardar um direito público ao recebimento de informações é necessário assegurar aos repórteres um direito de reter informações. Claramente, o propósito de proteger um repórter contra a divulgação forçada da identidade de uma fonte é possibilitar que ele obtenha e publique as informações
} 
Em um primeiro momento, a garantia de sigilo é um compromisso moral assumido pelo jornalista perante sua fonte - e a visão predominante de "ética jornalística" prescreve que ele deverá manter esse compromisso, a despeito de sofrer qualquer pressão ou sanção. Revelar a identidade de uma fonte após o compromisso de sigilo é considerado odioso, uma bala de prata para a credibilidade do jornalista ${ }^{162}$.

No cenário internacional, muitas publicações possuem regras internas para a utilização do sigilo de fonte. Em alguns casos, o repórter deve compartilhar as informações sigilosas com seu superior (o editor, por exemplo), que afiança a conveniência do uso da informação. Nos Estados Unidos, esse tipo de controle interno foi adotado por diversos veículos após casos em que repórteres produziram textos fantasiosos creditando suas informações a fontes sigilosas inexistentes - como o célebre caso do jornalista Jayson Blair ${ }^{163}$, do New York Times.

A concessão de uma blindagem jurídica ao jornalista fornece a segurança legal necessária para a manutenção do compromisso. Pode-se dizer que é uma prerrogativa bastante consolidada nos países democráticos ${ }^{164}$, ao ponto de se discutir se ela ela decorre diretamente da proteção constitucional conferida à "liberdade de imprensa" ou "liberdade de informação".

que de outro modo não viriam à tona (...). Assim, a informação 'off-the-record' obtida por um repórter em confiança é de suma importância para sua função. Frequentemente constitui o cenário de fundo que o permite reportar de maneira inteligente. Isso permite pistas que levam a notícias publicáveis e ao entendimento sobre eventos passados e futuros". Citado por Floyd Abrams: Speaking Freely: Trials of the First Amendment. New York: Penguin Books, 2005, p. 5.

${ }^{162}$ Discute-se se o jornalista pode abrir mão de seu compromisso de confidencialidade em casos excepcionais - como quando se descobre posteriormente que a fonte que lhe pediu sigilo divulgava informações que sabia serem falsas para prejudicar terceiros, por exemplo. Os casos em que jornalistas abdicam do sigilo de fonte são sempre controversos e bastante expostos e discutidos pelo próprio meio profissional.

${ }^{163}$ Em 2003, Jayson Blair pediu demissão de seu cargo de repórter, após o jornal descobrir que diversas reportagens suas eram plágios de jornais menores ou meras invenções, sempre creditadas a fontes sob sigilo.

164 "Em diversas nações européias, incluindo Alemanha, França e Austria, não há circunstâncias nas quais um jornalista deva ser levado a quebrar sua palavra dada às fontes confidenciais. Em outros países, como Japão, Canadá e Nova Zelândia, a regra é a de que fontes confidenciais são protegedias, com as exceções sendo poucas e limitadas. Na Suécia, por exemplo, não apenas as fontes confidenciais são protegidas, mas constitui uma ilegalidade um jornalista relevar suas identidades" - Floyd Abrams, Speaking Freely: Trials of the First Amendment, p. 280. 
A Corte Européia de Direitos Humanos, por exemplo, consolidou uma linha jurisprudencial protetora ao sigilo de fonte como garantia decorrente da liberdade de informação disposta pelo artigo 10 da respectiva Convenção, a despeito da existência de qualquer previsão específica naquele texto. A esse respeito, por exemplo: Goodwin v. Reino Unido (1996) ${ }^{165}$, Roemen e Schmit v. Luxemburgo $(2003)^{166}$ e Ressiot v. França $(2012)^{167}$.

A proteção ao sigilo de fonte no direito norte-americano já foi abordada em detalhes no capítulo 3. No caso brasileiro, sua proteção decorre expressamente de uma regra do texto constitucional, cujos principais aspectos serão analisados no próximo item 5.iii.

\section{5.a - A dimensão de "imunidade legal"}

Apontamos acima que a proteção ao sigilo de fonte certamente é o caso mais controverso e extremo entre as prerrogativas dos jornalistas.

${ }^{165}$ Em Goodwin v. Reino Unido (1996), a Corte julgou o recurso de um jornalista-trainee contra decisão judiciária inglesa que lhe obrigava a revelar a fonte de uma matéria na qual revelava um plano confidencial de reorganização financeira de uma companhia privada. A Câmara dos Lordes britânica havia julgado que a notícia colocava em risco a saúde financeira da empresa e os empregos de seus funcionários. Para a Corte Européia, "pela relação que possui com a importante proteção ao sigilo de fonte para a liberdade de imprensa em uma sociedade democrática e em razão de seus potenciais efeitos, uma ordem de quebra de sigilo não pode ser compatível com o artigo 10 da Convenção a não ser que justificada por um preponderante critério de interesse público".

${ }^{166}$ Em Roemen v. Schmit v. Luxemburgo (2003), um jornalista recorreu àquela Corte após ter tido expedido contra si mandados de busca e apreensão para serem cumpridos em sua residência e no escritório de seu advogado. Ele havia publicado uma matéria na qual revelou que um ministro de governo havia sido condenado a pagamento de multas por evasão fiscal, após ter acesso a documentos sigilosos vazados pelo órgão fazendário. $\mathrm{O}$ ministro requereu uma investigação criminal para descobrir qual servidor público havia vazado as informações. A Corte reconheceu que os mandados de busca e apreensão possuíam formal fundamento legal e que visavam a efetividade de uma investigação criminal e a manutenção da ordem pública. No entanto, decidiu que as autoridades nacionais não demonstraram um preponderante critério de interesse público para motivar suas ações e que, diante dos interesses em jogo, a decisão pecava pela ausência de proporcionalidade.

${ }^{167}$ Ressiot v. França (2012) condenou aquele país a indenizar quatro jornalistas que, em 2005, sofreram medidas de busca e apreensão em suas casas e nas redações onde trabalhavam. No ano anterior, eles publicaram reportagens em jornais esportivos contendo informações sigilosas de uma investigação da polícia francesa sobre dopping em provas de ciclismo - incluindo transcrições de escutas telefônicas. Foi a própria polícia que pediu autorização judicial para a medida, sob o argumento de investigar os vazamentos. A Corte considerou que "os meios usados não foram razoavelmente proporcionais às finalidades legítimas, considerando o interesse de uma sociedade democrática em assegurar e manter a liberdade de imprensa. Assim, houve uma violação do artigo 10 [da Convenção]". 
É possível dizer isso apenas pelo fato de que o sigilo de fonte é usado para levar ao público uma informação cuja publicidade certamente desagrada alguém caso contrário, o sigilo não seria necessário. Isso é importante compreender porque a informação repassada sob sigilo quase sempre é causa ou consequência de um conflito entre os atores envolvidos. O vazamento da informação, em regra, é um ato calculado pela fonte para otimizar seus interesses ou prejudicar interesses contrários ${ }^{168}$. O jornalismo, nesse aspecto, vale-se da miríade de interesses atuantes na sociedade para obter informações de interesse público que, de outro modo, permaneceriam ocultas.

Disso já decorre um sério problema: o uso do sigilo potencializa situações em que uma pessoa se sinta atingida pela informação publicada - potencialmente incorreta, falsa ou difamatória - e tenha interesse em submetê-la a escrutínio, o que normalmente implica revelar sua fonte.

No entanto, o caráter mais controverso do sigilo de fonte decorre da lógica de imunidade legal que está ligada à sua aplicação: uma imunidade que facilmente pode se tornar um obstáculo à investigação de crimes e demais ilegalidades, por exemplo.

Realizar uma interceptação telefônica sem autorização judicial ou violar um segredo de justiça, por exemplo, são condutas que constituem crime ${ }^{169}$. Se um jornalista receber o conteúdo de uma conversa gravada ilegalmente ou de um documento processual sigiloso e concluir que há interesse público em sua divulgação, ele não apenas irá potencializar os efeitos do crime (e os interesses de seu autor, eventualmente), mas também poderá colocar-se como um obstáculo para uma investigação, negando-se a relevar sua fonte. Decorre do próprio conceito da prerrogativa o corolário de que o jornalista não responde pela ilicitude na obtenção da informação pela sua fonte - exceto, é claro, se dela participou. Sob esse aspecto, ainda que não haja uma responsabilização jurídica direta do repórter, parece bastante

\footnotetext{
${ }^{168}$ O termo "interesse" deve ser compreendido em seu significado mais amplo possível: interesses financeiros, partidários, politicos, corporativos, relacionados à imagem pública de uma pessoa ou de um grupo, decorrentes de relações pessoais em suas mais diversas formas ou mesmo de um dever moral concebido por uma pessoa que deseja expor ao público algo que considera incorreto. Ao jornalista, segundo concepção corrente, cabe avaliar o interesse público contido nessa informação e publicá-la, ainda que isso, em segundo plano, atenda aos interesses privativos da fonte.

${ }^{169}$ Artigo 10 da lei 9.296/1996, que comina a pena de dois a quatro anos de reclusão, além de imposição de multa.
} 
evidente que a prerrogativa do sigilo de fonte, como regra jurídica, favorece a obtenção ilegal de informações.

Isso pode ser compreendido com uma "imunidade legal" na medida em que os cidadãos em geral possuem a obrigação de testemunharem sobre o que sabem quanto ao cometimento de um delito, sob pena de, eles próprios, cometerem o crime de falso testemunho ${ }^{170}$. É essa dimensão de "exceção legal" que faz do sigilo de fonte o caso mais extremo de diferenciação dos jornalistas em comparação com os cidadãos em geral.

Outras profissões também possuem sigilo profissional - $\operatorname{advogados}{ }^{171} \mathrm{e}$ médicos ${ }^{172}$, por exemplo. Seu uso nesses âmbitos, no entanto, é muito menos propenso a causar conflitos jurídicos com outros direitos fundamentais ou gerar situações tão controversas. Primeiro, porque os efeitos do sigilo se mantêm restritos a uma esfera privada de relação entre o cliente e o profissional, sem exposições públicas que contrariem os interesses de terceiros. Segundo, porque embora haja sigilo sobre seu conteúdo, a relação entre o cliente e o profissional em regra é pública. Por fim, provavelmente pela natureza mais privativa desse sigilo profissional, ele é considerado um dever de segredo pelo direito - daí que nao se pode compará-lo ao sigilo de fonte, que possui a dimensão de "imunidade legal": se um advogado ou médico desrespeitá-lo, será considerado incurso no crime de violação do segredo profissional ${ }^{173}$. Esse crime não se aplica ao sigilo jornalístico de fonte por ser considerado uma prerrogativa do próprio repórter, que pode dela abdicar, segundo suas convicções e critérios ${ }^{174}$.

\section{5.b- Prerrogativa absoluta ou relativa?}

\footnotetext{
${ }^{170}$ Artigo 342 do Código Penal.

${ }^{171}$ Artigo 34 do Estatuto da Ordem dos Advogados do Brasil (lei no 8.906/94).

${ }^{172}$ Artigo 11 do Código de Ética Médica (resolução no 1.246/88 do Conselho Federal de Medicina).

${ }^{173}$ Artigo 154 do Código Penal.

${ }^{174}$ No mesmo sentido: Maria Cecília Labate Maiolini Rebello Pinho, O sigilo da fonte como garantia da liberdade de informação jornalística. Dissertação de mestrado apresentada à Faculdade de Direito da Universidade de São Paulo em 2007, p. 46; Benedito Luiz Franco, Proteção constitucional do sigilo da fonte na comunicação jornalística. São Paulo: Celso Bastos, 1999, p. 118.
} 
Por se tratar de uma regra de "excepcionalidade" do sistema legal, torna-se naturalmente relevante indagar se o sigilo de fonte é uma prerrogativa absoluta ou relativa.

O debate sobre a relativização do sigilo de fonte sempre resulta de um embate entre "buscas pela verdade" que são juridicamente protegidas. Como aponta Linda Berger, "o objetivo da proteção ao sigilo de fonte é a defesa do processo de apuração e disseminação de informações necessárias ao autogoverno. Qualquer limitação a isso deve sopesar dois tipos de buscas pela 'verdade' - o direito do público a um livre fluxo de informações que levam à verdade e o direito do público aos depoimentos de testemunhas que levam à verdade" ${ }^{175}$.

Em regra, essa questão se apresenta quando uma reportagem divulga um ato ou esquema criminoso, o que costuma motivar policiais e promotores a intimarem o repórter para que, mediante testemunho, forneça as informações que viabilizem a persecução penal - e evitem, assim, uma situação de impunidade e imagem de incompetência das autoridades, amplificadas pela divulgação dos fatos ${ }^{176}$. Esse raciocínio costuma ignorar que nesses casos as investigações oficiais costumam surgir exatamente em função da publicação das reportagens que se valem de fontes sigilosas - e que, portanto, relativizar essa prerrogativa pode minar para casos futuros o próprio mecanismo que permitiu a divulgação dos fatos, em um primeiro momento, e a decorrente investigação, em um segundo. Como regra geral, é a situação padrão na qual se invoca e se aplica a proteção jurídica ao sigilo de fonte.

\footnotetext{
${ }^{175}$ Linda L. Berger, "Shielding the Unmedia: using the process of journalism to protect the journalist's privilege in an infinite universe of publication", Houston Law Review 39 (2003), p. 37.

${ }^{176}$ A situação é recorrente. No Brasil, em 2005, os jornais divulgaram que um procurador do Ministério Público Federal discutia com seus colegas em uma rede interna a possibilidade de quebrar o sigilo telefônico de quatro jornalistas nos autos de uma investigação pelo crime de "insider trading" ("Procurador tenta contestar sigilo de fonte", Folha de S. Paulo, reportagem publicada em 30.11.2005). Em 2011, na Inglaterra, o jornal The Guardian publicou uma série de reportagens que levaram ao fechamento do tablóide News of the World, após comprovar que várias de suas matérias tinham sido feitas com o uso de escutas ilegais, inclusive com participação de policiais. A chefia da Scotland Yard chegou a pedir ao judiciário - sem sucesso - o direito de obter dos jornalistas suas fontes, com o objetivo de punir seus servidores. Logo depois, a chefia policial desistiu da estratégia ("Metropolitan Police drop action against the Guardian", The Guardian, reportagem publicada em 20.09.2011).
} 
Dito isso, o caso Farber, ocorrido nos Estados Unidos, é um bom exemplo para ilustrar como a aplicação do sigilo de fonte pode ser ainda mais problemática do que naquelas situações, em especial quando confrontada por demais direitos fundamentais.

Myron Farber era repórter do New York Times em 1975, quando escreveu uma série de textos sobre mortes ocorridas em um hospital de New Jersey. As reportagens sugeriam que os médicos locais suspeitavam que um colega - chamado de Dr. X havia evenenado pacientes. Após as publicações, as investigações foram reabertas e o médico Mario Jascalevich foi indiciado por cinco homicídios, o que o levava à possibilidade de ser condenado à pena de morte.

No curso de seu julgamento criminal, seu advogado solicitou que as anotações de Farber fossem incluídas como provas no processo. Seu objetivo declarado era saber o que as fontes de Farber haviam dito para ele para que pudesse confrontar as informações com as provas processuais, incluindo testemunhos. $\mathrm{O}$ juiz deferiu o pedido da defesa técnica - e como Farber negou-se a cumpri-lo, sob o fundamento do sigilo de fonte ${ }^{177}$, foi condenado a seis meses de prisão pelo delito de desobediência.

O estado de New Jersey já possuía à época uma lei que garantia o sigilo de fonte para jornalistas, mas a suprema corte estadual decidiu que deveria prevalecer o direito constitucional do réu de ter acesso a quaisquer provas que pudessem comprovar sua inocência ${ }^{178}$. Farber ficou preso por 40 dias, até ser beneficiado por

\footnotetext{
${ }^{177}$ Farber e o New York Times argumentaram que a ordem para entrega das anotações não deveria ter sido emitida sem que o acusado tivesse demonstrado que elas eram relevantes ao julgamento, considerando informações que poderiam ser obtidas por outros meios. O juiz, então, determinou que as anotações fossem fornecidas em uma audiência privativa, para que ele apreciasse o pedido detalhadamente. Foi esse pedido que foi desobedecido pelo jornal e pelo repórter. Anthony Lewis, "A Preferred Position for Journalism?", Hofstra Law Review 7 (1979), pp. 610-611.

${ }^{178}$ A corte entendeu que, em regra, seria possível ao juízo realizar uma análise privativa da informação sob sigilo para decidir sobre sua manutenção, mas apontou que, naquele caso, por se tratar do direito constitucional de ampla defesa, esse procedimento sequer era necessário - Anthony Lewis, "A Preferred Position for Journalism?", p. 611. Para Floyd Abrams, que atuou como advogado do jornal e de seu repórter, "as decisões judiciais nesse caso foram absurdas. Um juiz chegou ao ponto de concluir que Farber serviu como 'um braço investigativo do Estado', que sua decisão de escrever um livro sobre o caso significava que ele atua 'sobre o altar da ganância' e, acima de tudo, de que ele tinha 'feito o mal'. Outro juiz concluiu que o Times havia 'lavado e alterado seus arquivos'. Ambos os juízes estavam errados sobre tudo; ambos pareciam para mim à época e ainda agora serem inadvertidamente parciais contra Farber e o Times" (Floyd Abrams, Speaking Freely: Trials of the First Amendment, pp. 289-290).
} 
um indulto concedido pelo governador. O médico, ao final do julgamento, foi absolvido.

Comentando o caso Farber, Ronald Dworkin fornece um interessante ponto de vista sobre o conflito entre o sigilo de fonte e direitos fundamentais. Para Dworkin, a maioria das análises sobre o caso partiu de uma premissa equivocada, segundo a qual o sigilo de fonte deveria ser compreendido como um princípio jurídico em colidência com outros princípios jurídicos. Segundo essas análises, deveria haver um balanceamento, cujo exato ponto de conciliação gerava divergência entre os intérpretes $^{179}$.

Dworkin propõe uma leitura diversa do problema. Para ele, "a prerrogativa reinvidicada por Farber não tem nenhuma relação com o direito político de expressão ou de publicação livre de censura ou restrições. Nenhuma autoridade ordenou-lhe que não investigasse ou não publicasse o que queria, nem ameaçou prendê-lo pelo que de fato publicou" ${ }^{\prime 180}$. Ele rejeita, portanto, que o sigilo de fonte seja uma implicação direta da Primeira Emenda.

Dworkin parte da distinção de normas jurídicas fundamentadas por princípios ou por razões de política ("policies"). Os princípios dizem respeito aos direitos constitucionais que, em função de um determinado fundamento moral, prevalecem com a característica de trunfos perante outras normas jurídicas, exceto se em conflito com outros princípios - também direitos constitucionais. É o caso, por exemplo do direito à igualdade e, como corolário, a proibição de discriminação ${ }^{181}$.

As normas fundamentadas por razões de política, por outro lado, justificam-se porque promovem um benefício para toda a coletividade, atingindo determinada finalidade social. Para Dworkin, esse é o caso, por exemplo, tanto de subsídios governamentais concedidos a fazendeiros quanto do sigilo de fonte para jornalistas ${ }^{182}$.

\footnotetext{
${ }^{179}$ Ronald Dworkin, "O caso Faber", Uma questão de principio. São Paulo: Martins Fontes, 2001, p. 558.

${ }^{180}$ Ronald Dworkin, "O caso Faber”, Uma questão de princípio, p. 558.

${ }^{181}$ Ronald Dworkin, "O caso Faber", Uma questão de principio, p. 558

182 "Sem dúvida é valioso para o público que os repórteres tenham acesso a informações confidenciais. Mas não é uma questão de direitos de ninguém". Ronald Dworkin, "O caso Faber", Uma questão de principio, pp. 558-559.
} 
A consequência mais importante dessa distinção é a seguinte: quando em conflito, as normas que veiculam princípios jurídicos devem prevalecer sobre as normas que veiculam razões para o bem-estar social (policies). Como Dworkin classifica o sigilo de fonte como policy, ele entende que essa prerrogativa não pode prevalecer sobre o direito constitucional do acusado à ampla defesa ${ }^{183}$.

A análise de Dworkin acerta ao evidenciar como a regra de proteção ao sigilo de fonte é instrumental à promoção da liberdade de informação. Não se trata de um valor em si, mas de uma prerrogativa - prevista por opção legislativa, no caso brasileiro - que fortalece o exercício daquele direito fundamental.

No entanto, com o objetivo de desenvolver em que medida o sigilo de fonte é ou não absoluto, é conveniente apontar que as categorias de normas jurídicas com que Dworkin trabalha não nos parecem as mais apropriadas ${ }^{184}$. Neste ponto, cabe invocar que proposta de Robert Alexy de distinguir as normas jurídicas entre regras e princípios serve para explicar de maneira mais completa tanto as consequências da proteção jurídica expressa ao sigilo de fonte, quanto os problemas decorrentes de sua superação ou relativização. Essa distinção já foi abordada na introdução deste trabalho, sendo desnecessário repetir aqueles argumentos.

Cabe aqui, porém, pontuar que o estabelecimento de regras jurídicas pelo legislador pode ser encarado como o resultado de um sopesamento de princípios jurídicos. Ou seja: no caso brasileiro, a proteção constitucional ao sigilo de fonte é uma decisão legislativa que expressamente opta por um arranjo normativo que privilegia a liberdade de informação, concedendo-lhe força significativa por meio de uma prerrogativa que favorece o livre fluxo de informações na sociedade, a despeito inclusive do eventual caráter ilícito de sua origem. Em outras palavras, o legislador constitucional já definiu em larga medida qual dos lados deve prevalecer nos casos de

\footnotetext{
${ }^{183}$ Ronald Dworkin, “O caso Faber”, Uma questão de princípio, p. 559.

${ }^{184}$ A classificação de Dworkin pressupõe a ideia de que, em caso de conflito, as normas de direitos fundamentais (princípios) irão sempre prevalecer sobre as normas que veiculam policies. Isso desconsidera que esse último tipo de norma tem como fundamento a implementação de um outro direito fundamental - ou seja, também há argumentos de "princípios" daquele lado da disputa - além de não dar o devido peso ao fato de que a "policy" é resultado de um sopesamento dotado de legitimidade democrática (porque feito pelo legislador) entre os princípios jurídicos envolvidos.
} 
"buscas pela verdade" juridicamente protegidas, como quando autoridades buscam obrigar repórteres a fornecer informações para suas investigações oficiais.

Por se tratar de uma regra constitucional, a questão sobre se o sigilo de fonte é absoluto ou não adquire alguns contornos específicos - e bastante problemáticos. A proteção ao sigilo é absoluta apenas na medida em que regras jurídicas o são. Como já exposto anteriormente, as regras jurídicas possuem a característica de veicularem direitos e deveres definitivos aos casos nos quais sejam consideradas aplicáveis. Nessa medida, é seguro afirmar que para a quase totalidade de casos a imunidade do sigilo de fonte deverá prevalecer, com a segurança que decorre de regra expressa pelo texto constitucional.

A questão se torna mais complexa diante da seguinte possibilidade: uma regra pode deixar de ser aplicada a um caso concreto se estiver em conflito com um princípio constitucional? Essa indagação por si só justifica trabalhos voltados exclusivamente a ela ${ }^{185}$. Para a finalidade desta dissertação - e com o objetivo específico de discutir o caráter absoluto ou relativo do sigilo de fonte - basta apontar que é possível admitir que uma regra jurídica deixe de produzir efeitos em um caso, mediante o entendimento que sua aplicação fere de maneira desproporcional um princípio jurídico que, à luz das circunstâncias fáticas e jurídicas analisadas, deva prevalecer.

Em termos mais concretos: pode-se dizer que uma análise sobre eventual afastamento da regra de proteção ao sigilo deverá levar em conta o quanto o princípio da liberdade de informação, no caso sob exame, promove um valor que deva prevalecer sobre outros valores constitucionais. Isso pode ser mais bem explicado com um contra-exemplo: suponha-se que um jornalista profissional publique uma reportagem que invada de modo inconteste a privacidade de uma celebridade. Por exemplo: expondo aspectos de sua vida íntima, no interior de sua residência, com uso de imagens e informações apresentadas sob o sigilo de fonte.

\footnotetext{
185 Para Virgílio Afonso da Silva, esse é "talvez o ponto mais complexo e menos explorado da teoria dos princípios" (Direitos Fundamentais: conteúdo essencial, restrições e eficácia, p. 51). Para uma análise dedicada a essa questão, ver: Rafael Scavone Bellem de Lima, Otimização de princípios, separação de poderes e segurança jurídica: o conflito entre princípio e regra. Dissertação de mestrado apresentada à Faculdade de Direito da Universidade de São Paulo em 2012.
} 
A celebridade se sente atingida pela publicação e argumenta, em resumo, que ela fere de modo injustificado seu direito à privacidade. Pode-se argumentar que o sigilo de fonte seria irrelevante nesse cenário, caso a celebridade quisesse apenas processar o veículo que divulgou as imagens e informações. Mas pode haver também um interesse legítimo em saber, por exemplo, quem entrou em determinada residência sem autorização (com cumplicidade de terceiros) ou furtou objetos, imagens ou dados pessoais, o que constituiria crime.

Se o argumento da celebridade é aceito, a regra do sigilo de fonte é superada pela preponderância, no caso concreto, do direito fundamental à privacidade. Para efetuar esse raciocínio, porém, é estritamente necessário avaliar se o uso do sigilo de fonte atende às razões que levam à proteção da liberdade de informação, intuitivamente ligada à noção de informações pública e socialmente relevantes. Quanto menor o interesse público em sua divulgação, mais chance de prosperar o argumento pela preponderância do direito fundamental colidente com a liberdade de informação.

Sob esse prisma, a decisão do caso Farber faz sentido e aparenta ser válida, diante da necessidade de garantir ao acusado em um processo criminal todos os meios de produção de prova que possam auxiliar sua defesa técnica ${ }^{186}$.

A justificativa pela preponderância do princípio jurídico sobre a regra, no entanto, deve ser forte o suficiente para desconsiderar, como medida de absoluta excepcionalidade, a opção expressa feita pelo legislador, no exercício de suas atribuições dotadas de legitimidade democrática. É necessário reconhecer um peso bastante relevante à capacidade decisória do legislador, sob pena também de erosão

\footnotetext{
${ }^{186}$ No mesmo sentido, a análise de Anthony Lewis: "O direito e o bom senso rejeitam a noção de que na sociedade apenas os jornalistas possuem um trunfo constitucional de sigilo. $\mathrm{O}$ interesse deles é bastante importante. Mas, no mundo real, ele irá inevitavelmente ser sopesado com outros interesses. Isso é evidente se pensarmos como as cortes considerariam - como o próprio público consideraria, de fato - se diversas partes tentassem obter a exata mesma informação de Farber. O sopesamento de interesses iria variar" - Anthony Lewis, "A Preferred Position for Journalism?", p. 614. Para Lewis, ainda, como a imprensa americana possui um alto nível de proteção em casos de difamação (por exemplo: New York Times Co. v. Sullivan), não pode esperar que possua também direito absoluto de sigilo de fonte, sob pena de inviabilizar ações judiciais de reparação em caso de ataques infundados. "A solução não é prender, mas supor que não houve tal fonte", abordagem que tem sido usada em vários estados (Anthony Lewis, Liberdade para as ideias que odiamos, p. 117).
} 
da expectativa de segurança jurídica e da legitimidade democrática. Em resumo, tratase de uma hipótese reservada apenas para casos expecionais ${ }^{187}$.

É claro que, formulada nesses termos, trata-se apenas de uma proposição prescritiva que busca dar sentido a uma determinada teoria de normas jurídicas. Esse problema depende muito mais do quanto as decisões judiciais manterão tais possibilidades retritas a casos muito específicos, que demonstrem um alto ônus argumentativo para a superação de regras. A proteção ao sigilo de fonte, como ocorre com qualquer outra regra jurídica, depende de como o judiciário em suas decisões fortalece ou relativiza essa prerrogativa - assim como depende de como essas decisões são recebidas e avaliadas pela sociedade.

No limite, torna-se uma questão de discutir o quanto as prescrições jurídicas são definitivas e previsíveis e, em um contexto mais amplo, saber se o judiciário é capaz de agir com sensibilidade e autocontenção para não se arvorar na condição de editores que decidem quais tipos de reportagens constituem jornalismo legítimo.

\section{5.c - A proteção ao sigilo de fonte na Constituição brasileira: uma} proposta interpretativa sob a abordagem funcional à liberdade de imprensa

O que em 1988 parecia o endosso constitucional de um instrumento favorável à democracia e à livre circulação de informações, vinte e cinco anos depois pode ser compreendido como uma regra datada e alheia às dificuldades contemporâneas de se determinar "quem é" a imprensa ou seu profissional ${ }^{188}$. Se forem aceitos como

\footnotetext{
${ }^{187}$ Ainda nesse contexto, a Corte Européia de Direitos Humanos, ao mesmo tempo em que reconhece a prerrogativa do sigilo de fonte como decorrência direta da liberdade de informação (tornando dispensável sua previsão por uma regra nacional), permite-se avaliar diretamente a proporcionalidade da medida estatal que visa restringi-la, quando um determinado caso apresenta uma colisão entre a liberdade de informação e outro princípio jurídico. Essa linha jurisprudencial afasta a necessidade de regras legislativas "criarem" a prerrogativa do sigilo de fonte e impõe um ônus argumentativo à atuação estatal que com ela colida. Ao mesmo tempo, a Corte relaciona-a costumeiramente à "liberdade de imprensa em uma sociedade democrática", sem se atentar às dificuldades de se diferenciar quem é parte desse grupo.

${ }^{188}$ Esse marco cronológico não é exclusivamente brasileiro; como visto no capítulo 2 (item 2.c), a segunda metade do século XX marca o auge da demanda da imprensa profissional por prerrogativas próprias. A constitucionalização do "sigilo profissional" para "a imprensa" também pode ser observada nas Constituições de Portugal (1976) e Espanha (1978). Curiosamente, a Constituição de Portugal trata em dispositivos diversos das liberdades de "informar, de se informar e de ser informado" (art. 37) e da "liberdade de imprensa" (art. 38), prevendo a proteção constitucional ao sigilo profissional neste último dispositivo. A Constituição da Espanha, por sua vez, prevê separadamente em seu art. 20 a
} 
procedentes os argumentos favoráveis à abordagem funcional da liberdade de imprensa - conforme perspectiva crítica apresentada no capítulo anterior -, é possível adotar o fundamento de que o critério "profissional/não profissional" constitui uma discriminação injustificada.

A regra constitucional de proteção ao sigilo de fonte profissional integra o texto original promulgado em 1988 e não pode ser considerada inconstitucional. Mas a defesa de uma abordagem funcional à liberdade de informação implica o seguinte problema: em que medida pode ser considerada injustificada (desproporcional) a recusa em se estender o sigilo de fonte a atividades que constituem (ou se equiparam) ao jornalismo, tradicionalmente assim reconhecido? Os jornalistas profissionais fariam jus a uma proteção que decorre de regra disposta pelo texto constitucional. Por outro lado, um cidadão comum que exerce uma atividade análoga poderia pleitear esse benefício em virtude de uma extensão dessa regra, decorrente de uma interpretação constitucional calcada na ideia de vedação à discriminação injustificada.

Nesse sentido, propõe-se uma abordagem similar à análise de Virgílio Afonso da Silva com relação à inclusão de posições jurídicas no âmbito de proteção de um direito fundamental, por meio de criação de regras jurídicas decorrentes de construção interpretativa e/ou jurisprudencial.

Para Silva, em alguns casos nos quais há uma colisão entre uma regra e um princípio, "é necessário incluir uma conduta, um estado ou uma posição jurídica na proteção de um direito fundamental", ainda que essa ampliação ultrapasse os limites previstos pela regra aplicável. Ele fornece como exemplo as decisões judiciais que reconheciam o direito de levantar os valores do Fundo de Garantia do Tempo de Serviço também quando o dependente do tiular era portador de HIV - a despeito de a legislação prever essa hipótese apenas para o caso de o próprio titular possuir a doença. O exemplo narra, segundo ele, uma aparente colisão entre tal regra legal e o direito constitucional à vida. Nesse caso, a jurisprudência teria criado uma nova regra

liberdade de "expressar e difundir livremente os pensamentos, idéias e opiniões mediante a palavra, a escrita ou qualquer outro meio de reprodução" e a liberdade de "comunicar ou receber livremente informação verdadeira por qualquer meio de difusão. A lei regulará o direito à cláusula de consciência e ao sigilo profissional no exercício dessas liberdades". 
jurídica, excepcionando a regra literal proibitiva (ou "não permissiva"), que passaria a valer também para os futuros casos semelhantes ${ }^{189}$.

Não se ignora que no caso proposto aqui a regra "a ser expandida" por aplicação de um princípio constitucional também possui esse nível de hierarquia normativa. Contudo, essa característica não constitui qualquer impeditivo, caso seja mantida a convicção de que uma situação diversa implica uma discriminação injustificada.

Em sentido análogo, também no âmbito de regras e princípios constitucionais, a vedação à discriminação injustificada parece ser o agumento central da decisão do Supremo Tribunal Federal que expandiu a proteção prevista por regra do texto constitucional a uniões estáveis homoafetivas ${ }^{190}$, ainda que diante de um comando que faz referência literal e textualmente restritiva à união "entre o homem e a mulher" $\left(\right.$ art. 226, $\left.\S 3^{\circ}\right)$.

\section{5.d - Critérios para a expansão do sigilo de fonte}

Ainda assim, subsiste um aspecto que por si só é apto a gerar controvérsias: a necessidade de construção de critérios que permitam avaliar se eventual conduta sob exame merece ser incluída no âmbito de proteção do sigilo de fonte.

Embora bastante ligados aos dispositivos legais locais, dois importantes precedentes norte-americanos, apresentados a seguir, ilustram essa questão: os casos O'Grady v. Superior Court of Santa Clara (Corte de Apelações da California) e Too Much Media LLC v. Hale (Suprema Corte de Nova Jersey) ${ }^{191}$.

\footnotetext{
${ }^{189}$ Virgílio Afonso da Silva, Direitos Fundamentais: conteúdo essencial, restrições e eficácia, pp. 5456.

${ }^{190}$ Ação direta de inconstitucionalidade $\mathrm{n}^{\circ} 4.227$ e arguição de descumprimento de preceito fundamental $\mathrm{n}^{\circ}$ 132; julgadas conjuntamente em 5 de maio de 2011, relator ministro Carlos Ayres Britto. A votação foi unânime.

${ }^{191}$ No capítulo 4 (item 4.c.i) já foram apresentados alguns casos da jurisprudência norte-americana para ilustrar a aceitação de uma abordagem funcional da liberdade de imprensa por cortes daquele país, sempre com relação à aplicação ou não do sigilo de fonte. As decisões a seguir, contudo, justificam-se nesse espaço por permitirem maior ênfase quanto ao uso de critérios decisórios para a resolução desses problemas jurídicos; além disso, são decisões recentes que se situam no contexto específico da liberdade de informação massificada pelo uso da internet.
} 


\section{5.d.i - O'Grady v. Superior Court of Santa Clara (2006)}

Em 2006, a Corte de Apelações da Califórnia decidiu o caso $O$ 'Grady v. Superior Court of Santa Clara. A empresa Apple havia processado dois websites especializados em notícias de tecnologia, bem como seus servidores de e-mail, por terem divulgado os planos de lançamento de um mecanismo de gravação de áudio digital - ainda inédito. A empresa objetivava descobrir as fontes que vazaram seus segredos industriais (provavelmente empregados da empresa, todos submetido a regime de sigilo).

Em seus argumentos, a Apple sustentou que Jason O'Grady, um dos editores do website PowerPage: (a) não praticava jornalismo legítimo quando obteve as informações confidenciais; (b) não estava incluído na classe de pessoas protegidas pela legislação estadual de proteção ao sigilo de fonte ${ }^{192}$.

A corte terminou por reconhecer o direito de sigilo de fonte a ambos, em virtude de ter interpretado que websites deveriam ser compreendidos como "publicações periódicas" - o que, segundo a legislação estadual, garantia-lhes o sigilo de fonte. Nesse ponto, a decisão reconheceu como plenamente aplicável a regra vigente, mas o fez sobre uma analogia entre os websites e as publicações da imprensa tradicional $^{193}$.

\footnotetext{
${ }^{192}$ No texto original da Constituição da California: "A publisher, editor, reporter, or other person connected with or employed upon a newspaper, magazine, or other periodical publication... shall not be adjudged in contempt... for refusing to disclose the source of any information procured while so connected or employed for publication in a newspaper, magazine or other periodical publication, or for refusing to disclose any unpublished information obtained or prepared in gathering, receiving or processing of information for communication to the public".

${ }_{193}$ "A corte concluiu ao final que os autores dos websites eram de fato 'publishers'. Ela afirmou que websites destinados a notícias, como o dos peticionários, são 'como' um jornal ou uma revista para tais propósitos. A corte atingiu essa decisão e declarou que o website estava dentro da categoria definida pela legislação da California como 'revistas e outras publicações periódicas'. Ao chegar a essa decisão, a corte analisou os seguintes fatores: (1) definição de 'e-zines'; (2) a inclusão de 'outras publicações periódicas' no texto legal; (3) a extensão pela qual o website dos peticionários é 'altamente análoga às publicações impressas: que consite predominantemente em texto em 'páginas' que o leitor 'abre', lê em seu próprio ritmo, e 'fecha'; (4) a potencial distinção entre websites e 'blogs' (embora a corte tenha evitado usar a palavra 'blog' por causa de sua 'rápida transformação e significado atual amórfico'); e (5) a freqüência da publicação" - Carol J. Toland, "Internet Journalists and the Reporter's Privilege: Providing Protection for Online Periodicals", The Kansas Law Review 57 (2008), p. 476.
} 
Dois fundamentos subsequentes também foram determinantes para a decisão, no sentido de manter a linha jurisprudencial que prevê a superação judicial do sigilo apenas para casos excepcionais: primeiro, o fato de que a Apple havia falhado em demonstrar que não poderia identificar as fontes dos vazamentos por outros meios investigativos menos gravosos, que não resultassem na obrigação dos editores de abrirem mão do sigilo de suas fontes. A empresa deixou de entrevistar seus próprios empregados sob o dever legal de testemunho verdadeiro e também não forneceu relatórios sobre acesso aos arquivos eletrônicos em seus sistemas internos. Em segundo lugar, a corte enfatizou que, ainda que essa demonstração tivesse sido feita, poderia considerar que a informação era dotada de relevância pública suficiente para não ordenar a quebra do sigilo.

Em um exemplo pertinente da adoção de modelo de "imprensa aberta", os juízes, em decisão unânime, adotaram expressamente o fundamento do "livre mercado de idéias": "nós declinamos o convite implícito para que nos debrucemos sobre questões sobre o que constitui ‘jornalismo legítimo'. A lei de proteção ao sigilo de fonte pretende proteger a apuração e disseminação de notícias, e é isso o que os peticionários fizeram aqui. Nós não podemos imaginar nenhum teste ou princípio funcional que iria distinguir notícias 'legítimas' de 'ilegítimas'. Qualquer tentativa de uma corte de delinear essa distinção iria colocar em perigo o propósito fundamental da Primeira Emenda, que é identificar as ideias mais importantes, mais valiosas e melhores não por alguma fórmula econômica ou sociológica, regra jurídica ou processo de governo, mas por meio da dura competição do mercado de ideias".

\section{5.d.ii - Too Much media LLC v. Hale (2011)}

Em 2011, a Suprema Corte de Nova Jersey decidiu o caso Too Much Media $L L C$ v. Hale. Tratava-se de um processo de difamação daquela empresa contra Shelle Hale - que, em um fórum de discussão na internet ("bulletin board"), havia postado comentários contra a empresa e seus diretores, ligando-os a práticas ilícitas. Instigada a comprovar suas denúncias, Hale invocou o sigilo de fonte garantido pela legislação estadual, sob o argumento de que havia recebido informações sob sigilo. Hale possuía também um blog pessoal, além de operar dois websites. Ela havia declarado que pretendia lançar um website dedicado a publicar as notícias sobre práticas ilícitas da 
indústria pornográfica, na qual atuava a empresa autora - mas isso não chegou a acontecer.

Embora a corte tenha decidido que Hale, naquele caso, não poderia fazer uso do sigilo de fonte, a decisão reverteu expressamente os fundamentos de uma instância judicial inferior, que havia decidido que o sigilo de fonte aplicava-se somente a jornalistas profissionais credenciados por veículos tradicionais ou que aderissem aos parâmetros profissionais consagrados.

A Suprema Corte de Nova Jersey afastou a prerrogativa de sigilo de fonte de Hale porque a legislação estadual, a seu ver, demanda que a liberdade de informação seja exercida por meio de uma publicação - online ou impressa - de conteúdo similar ao jornalismo tradicional. Nesse ponto, foi considerado que comentários em um fórum de discussões na internet não alcançam esse requisito: "embora a lei de proteção ao sigilo de fonte não limite sua aplicação às fontes de notícias tradicionais, ela especificamente requer que os outros meios de disseminação de notícias sejam 'similares' aos jornais, revistas e afins". A corte decidiu, ainda, ser irrelevante o caráter profissional do indivíduo: "independendemente, a lei determina uma conexão entre a mídia ('news media') e o propósito de apurar e disseminar notícias; ela não limita o privilégio a jornalistas profissionais que seguem certas normas".

A princípio, essa decisão também se vale de uma abordagem funcional à liberdade de imprensa, nos termos acima. Embora a corte tenha se manifestado pela irrelevância de normas jurídicas federais ao caso (incluindo-se a Constituição), em virtude da existência de uma lei estadual sobre o sigilo de fonte, um ponto fundamental do julgado gira em torno do significado do termo news media - que pode, nesse contexto, ser compreendido como "imprensa": "a existência de uma nova tecnologia apenas amplia o possível espectro do que a lei de proteção ao sigilo de fonte pode abarcar - do jornalismo diário impresso, a websites como o drudgereport.com, a salas de chat, blogs pessoais, e afins. Mas esses formatos expandidos são simplesmente o mecanismo para entrega de informações. A forma por 
si só não nos diz se um método particular de disseminação caracteriza-se como imprensa ('news media') sob a legislação" ${ }^{194}$.

Ao final, a decisão propôs uma expansão "cautelosa" do sigilo de fonte para "não profissionais": "no caso de um jornal com laços com a mídia tradicional, a certificação poderia facilmente ser demonstrada prima facie. Um advogado da parte contrária normalmente teria muita dificuldade em contestar essa certificação de um jornal tradicional ou de um repórter de televisão, por exemplo. No entanto, jornalistas auto-intitulados ou entidades com pouco histórico que reclamem o privilégio do sigilo demandam um maior escrutínio. Como a corte de apelações apontou, a popularidade da internet resultou em milhões de bloggers que não têm nenhuma conexão com a mídia tradicional. (...) Qualquer um deles, assim como qualquer um com uma conta no Facebook, poderia reclamar o uso do privégio. Nesses casos, uma audiência de instrução seria provavelmente necessária para determinar se o privilégio se aplica (...). As audiências não devem desenvolver indagações extensas sobre o processo editorial, intelectual ou de escrita do autor. E, do mesmo modo, devem evitar a exposição do material que o sigilo de fonte visa proteger".

\section{5.d.iii - Propostas doutrinárias}

As decisões expostas nos itens anteriores demonstram que, ainda que se assuma uma abordagem funcional de imprensa como fundamento dos direitos fundamentais envolvidos, subsiste a necessidade de construção de critérios que permitam avaliar se uma eventual conduta sob exame merece ser incluída no âmbito de proteção do sigilo de fonte.

\footnotetext{
${ }^{194}$ Alguns precedentes de reconhecimento de sigilo de fonte são citados pela decisão para justificar a pertinência dessa abordagem funcional: (a) caso Ávila, referente a um tablóide gratuito em língua espanhola que, embora não alcançasse os requisitos para ser considerado um "jornal" nos termos da lei (porque sua edição não era vendida), era "suficientemente similar" para ser considerado como integrante da "news media"; (b) um material de filmagem de um pronto-socorro, para ser utilizado em um "reality show" da televisão, também foi considerado como integrante desse conceito; (c) caso O'Grady v. Superior Court, já mencionado acima; (d) um caso referente ao website Drudge Report que, embora tenha começado como uma coluna de fofocas sobre celebridades, evoluiu para o que a corte considerou um veículo de notícias não convencional, como semelhanças suficientes aos órgãos tradicionais da "news media".
} 
Uma primeira possibilidade é utilizar a imprensa profissional e consagrada como parâmetro. No direito norte-americano, Linda Berger - que também promove uma defesa da abordagem funcional da liberdade de imprensa - trilha esse caminho.

Ela defende que a prerrogativa do sigilo de fonte seja reconhecida para qualquer cidadão, desde que a função informativa desempenhada adote alguns critérios consagrados pela imprensa profissional: “o processo jornalístico protegido juridicamente pode ser definido como o trabalho que demonstra um compromisso com a disseminação regular e pública de 'verdade jornalística'. De um modo geral, alguns componentes ou ferramentas universalmente aceitos de processo jornalístico podem ser identificados. Três componentes parecem ser razoavelmente suscetíveis a uma análise objetiva, que não leve as cortes a invadirem o processo editorial ou interferirem sobre a indepedência jornalística: (1) o registro histórico de publicações passadas; (2) a presença de mecanismos de verificações internas e (3) a disponibilidade de informações que permitam aos leitores avaliar a independência do veículo" ${ }^{195}$.

Para Berger, conceder sigilo de fonte aos profissionais é algo muito limitado; concedê-lo a qualquer um que dissemine notícias é muito subjetivo - e concedê-lo baseado no meio da publicação é irrelevante ${ }^{196}$. Em síntese, Berger busca nos parâmetros da imprensa profissional algumas balizas que garantam uma demonstração de estabilidade e credibilidade da atividade como condições para a concessão do sigilo.

Berger entende ainda que não é possível o judiciário decidir pela proteção ou não do sigilo de fonte com base no conteúdo da informação. Para ela, juízes não podem passar a decidir o que deve ou não deve ser notícia, sob pena de se tornarem eles próprios editores das informações e guardiões do "bom gosto" público. Além

\footnotetext{
${ }^{195}$ Linda Berger, "Shielding the Unmedia: using the process of journalism to protect the journalist's privilegile in an infinite universe of publication", 39 Houston Law Review (2003), pp. 33-34. Com relação a esses três critérios, Berger exemplifica algumas questões: "(1) As informações são disseminadas com regularidade? São disseminadas publicamente? Elas são usualmente verdadeiras?"; "(2) Existem mecanismos internos para avaliar e checar informações antes de serem distribuídas ao público?”; (3) Quem é o proprietário ou financiador da publicação? Para quem os publishers e repórteres trabalham? Quais são os padrões editoriais reconhecidos e seguidos pelo veículo?"(p. 38).

${ }^{196}$ Linda Berger, "Shielding the Unmedia", p. 33.
} 
disso, uma análise desse tipo "erra o alvo: é a apuração da informação e não sua publicação que está sendo protegida. Mandados judiciais em casos criminais são normalmente emitidos antes que haja qualquer publicação" 197.

Mary-Rose Papandrea igualmente defende uma abordagem funcional de liberdade de imprensa que garanta a proteção do sigilo de fonte de maneira ampla e genérica.

Para Papandrea, contudo, Berger está equivocada em sua proposta por duas razões principais: (i) primeiro, porque presume que a proteção do sigilo de fonte só deve ser concedida àquelas pessoas cujas atividades aproximem-se de um "jornalismo ideal”, que reflete os cânones da mídia tradicional. Ela lembra que mesmo alguns jornalistas profissionais se afastam dos critérios defendidos por Berger; ademais, autores de livros ou de documentários teriam dificuldade em articular quais são seus "princípios editoriais"; (ii) em segundo lugar, a proposta de Berger criaria um risco de ingerência inconstitucional de juízes no processo editorial, por se tratar de uma consequência imediata de sua exigência ${ }^{198}$.

Após analisar os precedentes judiciais sobre o tema, Papandrea conclui, em síntese, que no sistema norte-americano o sigilo de fonte deve ser um "privilégio qualificado" presumido a qualquer cidadão que dissemine informações ao público. Esse privilégio pode ser superado se: (i) a informação buscada for crítica para um interessado formular sua defesa, seu pedido em juízo ou para fazer prova de um fato; (ii) a informação não puder ser obtida por meios alternativos; (iii) há um interesse público preponderante na obtenção da informação sob reclamo de sigilo que supera o interesse público no fluxo livre de informações ${ }^{199}$.

Papandrea propõe ainda a seguinte regulamentação para o reconhecimento do sigilo como "privilégio qualificado": (i) a proteção também incide para réus em ações por difamação no direito americano; (ii) a proteção não se aplica para testemunhas ou

\footnotetext{
${ }^{197}$ Linda Berger, "Shielding the Unmedia", pp. 36-37.

${ }^{198}$ Mary-Rose Papandrea, "Citizen Journalism and the Reporter's Privilege”, pp. 583-584.

${ }^{199}$ Mary-Rose Papandrea, "Citizen Journalism and the Reporter's Privilege", p. 584. Nesse aspecto, a proposta de Papandrea é bastante próxima ao voto do juiz Potter Stewart, acompanhado de outros dois juízes, no caso Branzburg v. Hayes, conforme exposto no capítulo 3 (item 3.c).
} 
partícipes de um crime; ${ }^{200}$ (iii) aplica-se uma exceção à proteção em caso de risco iminente e direto à segurança nacional ou de possibilidade de ameaça à integridade física ou à vida de alguém; (iv) aplica-se uma exceção aos casos em que a publicação - especialmente na internet - tiver sido feita com indícios de tentar evitar uma ordem judicial $^{201}$.

Por fim, Papandrea entende que o sigilo de fonte não é conseqüência do interesse público constante na informação, por se tratar de conceito extremamente indeterminado e cuja avaliação, se restrita a assuntos de governo ou política, coloca em risco noções basilares de democracia e autogoverno ${ }^{202}$.

\section{5.d.iv - Perspectiva crítica e propostas}

A partir dos argumentos de Berger e Papandrea e à luz de outros debates expostos anteriormente, torna-se conveniente apresentar e defender alguns critérios que norteiem a aplicação da regra constitucional do sigilo de fonte, conforme a interpretação constitucional proposta neste capítulo.

(1) A princípio, a proposta de Berger de utilizar os cânones do "jornalismo profissional ideal" para a aplicação do sigilo de fonte teria um possível argumento adicional no caso brasileiro, já que se trata de critério expressamente previsto pela regra constitucional protetiva, o que poderia justificar seu uso como parâmetro comparativo.

Nesse ponto, contudo, Papandrea parece ter razão em sua crítica. A proposta de Berger parte de uma premissa equivocada de que os próprios veículos profissionais observam sempre tais critérios - o que certamente não constitui uma perspectiva realista. Tampouco os critérios profissionais predominantes são homogêneos ou

\footnotetext{
${ }^{200}$ Papandrea especifica que, segundo sua própria proposta, o repórter Paul Branzburg - que nomeia o respectivo caso da Suprema Corte - não faria jus ao sigilo, pois a reportagem em questão fazia uma cobertura da atividade ilícita de consumo de haxixe. A esse respeito: capítulo 3 (item 3.c).

${ }^{201}$ Mary-Rose Papandrea, "Citizen Journalism and the Reporter's Privilege", pp. 585-590.

202 "Alguns acadêmicos sugeriram que o sigilo de fonte deveria ser aplicado apenas àqueles que publiquem informações que envolvam assuntos de interesse público, típicos de governo ou de política. Embora essa visão seja tentadora, as dificuldades práticas e teóricas de tal regra são insuperáveis" Mary-Rose Papandrea, "Citizen Journalism and the Reporter's Privilege", p. 578.
} 
estáveis. No mais, é exatamente a restrição que esse padrão impõe - ainda que por regra constitucional - que se contesta neste trabalho, ao considerar sua utilização uma discriminação injustificada à luz dos fundamentos de uma abordagem funcional.

(2) Faz sentido, por outro lado, avaliar se uma determinada atividade é realizada com a intenção de gerar uma disseminação de informações relevantes ao público, de modo amplo e indistinto. Isso poderia ser avaliado tanto pelo histórico de uma pessoa ou organização (i.e., existência de publicações anteriores) quanto por outros tipos de evidências (i.e, comprovação de que uma pesquisa em andamento destina-se a futura publicação de um livro). Esse critério exclui atividades que tenham uma finalidade de destinação privativa e puramente comercial - como venda de banco de dados ou divulgação de pesquisas e informações a clientes restritos.

(3) Berger suscita um aspecto importante ao sugerir que uma determinada publicação deve transparecer quem é seu proprietário ou financiador.

Se a objetividade jornalística pura não é crível $^{203}$ e, como corolário, a isenção tampouco é condição necessária ou realista ao jornalismo ${ }^{204}$, um cidadão só pode avaliar uma atividade informativa e seus potenciais vieses se ele puder conhecer quem responde ou toma decisões em seu nome. Um blog anônimo, por exemplo, não alcançaria esse critério - o que, no mais, estaria em consonância com a regra constitucional que veda o anonimato (art. $5^{\circ}$, inciso IV).

(4) Ao contrário do que propõe Papandrea, não se pode afastar de plano a proteção do sigilo de fonte em casos de investigação criminal no qual um jornalista é uma potencial testemunha. Conforme argumentação exposta anteriormente ${ }^{205}$, a prerrogativa é uma espécie de imunidade quanto ao dever legal de testemunho - e superar essa proteção demanda uma excepcionalidade jurídica que não pode ser aplicada como regra geral.

\footnotetext{
${ }^{203}$ Capítulo 4 - item 4.e.iii

${ }^{204}$ Capítulo 4 - item 4.e.iv.

${ }^{205}$ Capítulo 5 - itens 5.a e 5.b.
} 
(5) Feitas essas considerações, parece acertada a proposta de Papandrea de reconhecer como aplicável a priori a prerrogativa do sigilo de fonte para qualquer atividade reconhecida, sob um aspecto funcional, como liberdade de informação jornalística. Quanto a esse ponto, reiteram-se os argumentos exposto no item “jornalismo como atividade", no capítulo anterior ${ }^{206}$.

Ou seja: a prerrogativa deve ser presumida para qualquer atividade abarcada pelo âmbito de proteção daquele direito fundamental - o que, ademais, implica reconhecer que circunstâncias fáticas e jurídicas podem apontar para a superação da prerrogativa, no momento de uma solução jurídica definitiva.

\section{5.e - A possibilidade de criação de regras pelo legislativo}

Ainda que se defenda a expansão da proteção do sigilo de fonte para não profissionais no âmbito da interpretação constitucional, considerando os fundamentos já apresentados, é necessário ressaltar também o papel legislativo de criação de regras jurídicas nesse tema.

Como visto ao longo dos últimos capítulos, o sigilo de fonte pode suscitar inúmeros e intricados problemas jurídicos. Nesse sentido, a decisão feita em 1988 de constitucionalizar essa prerrogativa não impede que haja uma regulamentação legislativa sobre o tema - a exemplo do que também pode ocorrer, por exemplo, com o "direito de resposta" (artigo $5^{\circ}$, inciso V).

Se, por um lado, a ausência dessa regulamentação não impede a plena aplicação da regra constitucional, é possível afirmar que há espaço para regras legistivas que desenvolvam parâmetros práticos mais específicos.

De fato, essa regulamentação chegou a existir por meio do art. $7^{\circ}$ da Lei de Imprensa (lei $\mathrm{n}^{\circ}$ 5.250/67), declarada pelo STF em 2009 como não recepcionada pela

\footnotetext{
${ }^{206}$ Capítulo 4 (item 4.e.ii).
} 
Constituição de $1988^{207}$. Tal regra previa: “será (...) asssegurado e respeitado o sigilo quanto às fontes ou origem de informações recebidas ou recolhidas por jornalistas, radiorrepórters ou comentaristas". A própria inclusão da categoria de "comentaristas" nesse rol denota a dificuldade de se diferenciar quem é ou não "imprensa" - afinal, qualquer um pode comentar sobre qualquer assunto, inclusive em caráter eventual.

Esse exemplo histórico - embora não mais vigente - demonstra como qualquer eventual regulamentação legislativa também poderia sofrer objeções constitucionais com fundamento em uma abordagem funcional à liberdade de imprensa, na linha dos argumentos já apresentados. Afinal, caso aquela lei ainda fosse aplicável, poderia se buscar uma extensão da proteção que “jornalistas, radiorrepórteres e comentaristas" expressamente possuíam também para documentaristas, escritores, videorrepórteres e afins.

De qualquer modo, uma possível regulamentação poderia ser mais adequada para lidar com as preocupações expostas por este trabalho: regras legislativas podem deixar clara a possibilidade de aplicação do sigilo de fonte para não-profissionais ou estabelecerem alguns critérios funcionais para o reconhecimento da liberdade de informação jornalística - a exemplo do que fazem algumas legislações estaduais americanas $^{208}$.

Ou seja: ainda que se entenda como corretos os fundamentos de uma abordagem funcional à liberdade de imprensa, resta uma considerável margem de criação para o legislativo regular a matéria ${ }^{209}$.

\section{5.f - Considerações finais do capítulo}

\footnotetext{
${ }^{207}$ A decisão do STF na arguição de descumprimento de preceito fundamental no 130 declarou inválida a Lei de Imprensa porque, segundo a maioria dos ministros, ela possuía um viés autoritário e conflitante com as liberdades constitucionais democráticas.

${ }^{208}$ Por exemplo, os casos O'Grady v. Superior Court of Santa Clara (item 5.iv.a) e Too Much media LLC v. Hale (item 5.iv.b), mencionados neste capítulo 5.

${ }^{209}$ É interessante anotar que a própria decisão Too Much Media LLC v. Hale insta o poder legislativo a se debruçar sobre o assunto: "A legislação é livre para expandir a cobertura legal como uma medida de política ('policy'). Em uma era de tecnologia em constante transformação, com novos e modificáveis modos de comunicação, a legislação pode escolher reconsiderar quem é um jornalista e adicionar critérios à lei de proteção do sigilo de fonte. Nós não estamos fechando essa discussão na data de hoje; estamos simplsmente interpretando uma lei existente".
} 
O sigilo de fonte de jornalistas é uma prerrogativa amplamente aceita em regimes democráticos. E, como visto no início deste capítulo, é uma prerrogativa apta por si só a gerar consideráveis controvérsias. Inicialmente, busquei apresentar os aspectos jurídicos relevantes e polêmicos, próprios a qualquer discussão sobre o sigilo de fonte.

Feitas essas considerações, propûs-me a analisar a regra constitucional brasileira e defender parâmetros interpretativos para sua aplicação, à luz das questões propostas inicialmente pela pesquisa e dos argumentos desenvolvidos nos capítulos anteriores. 


\section{Conclusões gerais}

Ao longo deste trabalho, foram feitas considerações finais em cada capítulo, com o objetivo de explicitar a relevância de suas respectivas argumentações e de conectá-los conjuntamente com o tema proposto. Neste tópico final, apresento as conclusões finais e gerais que sintetizam o término da pesquisa.

O ponto de partida do trabalho foi a regra constitucional de proteção ao sigilo de fonte para profissionais. Como apresentado desde o capítulo introdutório, a ruptura de um modelo vertical e centralizado de comunicação, causado pelas recentes condições tecnológicas, gera dúvidas naturais quanto à aplicação do sigilo. No caso brasileiro, o tema torna-se alvo de indagações também em função da recente decisão do STF que declarou inconstitucional a exigência obrigatória do diploma de jornalismo para a profissão.

O pano de fundo do trabalho, portanto, é uma discussão sobre a possibilidade de o Estado diferenciar jornalistas de demais cidadãos, em especial para a concessão de prerrogativas jurídicas.

O direito norte-americano mostrou-se extremamente fértil para esse debate. Em um país notório por propagar a retórica da liberdade de imprensa, sua Suprema Corte possui, ao menos até hoje, uma posição clara de esvaziar o sentido tradicional ou ao menos intuitivo - desse conceito, ao não diferenciar cidadãos quanto ao exercício e prerrogativas de liberdade de informação ou de expressão.

De qualquer modo, a jurisprudência norte-americana é provavelmente uma exceção ao modo tradicional de refletir sobre a liberdade de imprensa- o que a torna especialmente interessante. No mais, a existência desse debate por décadas nos Estados Unidos demonstra como as reflexões propostas por esta pesquisa não são causadas pelos avanços tecnológicos e pela internet - embora possam ser intensificadas ou mais relevantes por causa delas. 
Como visto, a jurisprudência da Suprema Corte não é isenta de críticas. A apresentação das abordagens "institucional" e "funcional" à liberdade de imprensa buscou demonstrar essa polêmica, instalada no âmbito acadêmico. Essas duas concepções parecem ser inconciliáveis, levando a uma encruzilhada interpretativa. O trabalho buscou demonstrar os melhores argumentos de cada lado, fiel à pesquisa bibliográfica. O julgamento do recurso extraordinário 511.961 pelo STF foi analisado à luz desses argumentos.

Contudo, para possibilitar uma análise da regra constitucional do sigilo de fonte no Brasil, foi inevitável assumir alguns fundamentos jurídicos. Nesse sentido, deixei clara uma predileção pela visão funcional de imprensa (ou de "jornalismo"), recorrendo, entre outros argumentos apresentados pelos autores citados, à teoria dos direitos fundamentais como princípios jurídicos.

Compreender a liberdade de imprensa (ou "jornalismo") como atividade parece se aproximar de uma visão dogmática que preza pela proteção a priori de direitos fundamentais e enfatiza a necessidade de se apresentar ônus argumentativos para justificar restrições. Uma visão institucional de imprensa, por outro lado, parece decorrer da ideia de um suporte fático restrito para esse direito fundamental.

A partir dessas considerações, busquei propor parâmetros interpretativos para compreender e aplicar a regra constitucional do sigilo de fonte, diante das questões levantadas por este trabalho. Essa análise foi feita em um nível abstrato, a partir de precedentes judiciais norte-americanos, bem como de argumentos doutrinários.

Embora alguns episódios no Brasil já tenham criado consideráveis polêmicas após divulgação de informações sigilosas por indivíduos na internet ${ }^{210}$, nenhum deles,

\footnotetext{
${ }^{210}$ Em fevereiro de 2011, o blog pessoal do jornalista profissional Fabio Pannunzio divulgou um vídeo que mostrava delegados da Corregedoria da Polícia Civil de São Paulo despindo à força uma investigadora de polícia, suspeita de receber propina para evitar prisões em flagrantes. Pouco depois, o vídeo também foi divulgado em telejornal da TV Bandeirantes, onde o jornalista trabalha. O vídeo, feito pela própria Corregedoria, integrava um procedimento sigiloso daquele órgão. $\mathrm{O}$ vazamento do vídeo motivou ampla cobertura da imprensa e provocou a troca da chefia da Corregedoria.

Em março de 2011, o jornal Folha de S. Paulo publicou reportagem na qual narrava que um sociólogo que integrava a equipe da Secretaria de Segurança Pública de São Paulo possuía uma empresa de consultoria que, em seus contratos, fornecia a clientes dados públicos mantidos oficialmente sob sigilo. A reportagem valia-se de sigilo de fonte para documentar sua narrativa. Dias depois, o blog do
} 
até onde sei, deu causa a processos judiciais cujos argumentos pudessem ser pesquisados.

Espero, de um modo geral, que as reflexões propostas sejam originais e instigantes àqueles que se interessam pelos temas da liberdade de expressão, liberdade de imprensa ou interpretação constitucional. Quando abordam esses direitos fundamentais, em especial, as obras jurídicas brasileiras costumam adotar um tom laudatório e estéril. Talvez os argumentos apresentados aqui sirvam para resolver casos concretos nessa temática. Mas creio que cumprirão seu papel se motivarem uma reflexão singular sobre as visões e fundamentos possíveis para as liberdades constitucionais de imprensa e de informação.

radialista João Alkmin divulgou um vídeo feito pelo circuito interno de filmagem de um shopping na Capital, que revelava um encontro, dias antes da publicação da reportagem, entre o repórter responsável e o secretário de Estado de Segurança Pública. Esse material teria sido solicitado ao shopping por policiais civis e vazou rapidamente para blogs da internet. A publicação desse vídeo dava a entender que o próprio secretário havia repassado ao jornal o material que comprometia seu subordinado. Essa segunda revelação trouxe ao público a comprovação de que havia uma disputa de bastidores ao redor do controle da Secretaria de Segurança Pública, que envolvia grupos da polícia civil ligados ao atual e ao ex-secretário da pasta. 


\section{Bibliografia}

Abrams, Floyd. "The Press is Different: Reflections on Justice Stewart and the Autonomous Press", Hofstra Law Review 7 (1979): 563-593.

. Speaking Freely: Trials of the First Amendment. New York: Penguin Books, 2005.

. "Why Wikileaks is unlike the Pentagon Papers", The Wall Street Journal, artigo publicado em 29.12.2010.

Anderson, David. "The Origins of the Press Clause", University of California Law Review 30 (1983): 455-541.

. "Freedom of the Press", Texas Law Review 80 (2002): 429-530.

. "Freedom of the Press in Wartime", University of Colorado Law Review 77 (2006): 49-99

. "Confidential Sources Reconsidered", Florida Law Review 61 (2009): 883-

910.

Alexy, Robert. Teoria dos direitos fundamentais. São Paulo: Malheiros, 2008.

Allen, David. "The Institutional Press and Professionalization: Defining the Press

Clause in Journalist's Privilege Cases", The Free Speech Yearbook 34 (1997): 49-62.

Balkin, Jack M. "How Rights Change: Freedom of Speech in the Digital Era”, Sidney Law Review 26 (2004). 
Barroso, Luís Roberto. "Liberdade de expressão versus direitos da personalidade. Colisão de direitos fundamentais e critérios de ponderação", Temas de direito constitucional: Tomo III. Rio de Janeiro: Renovar, 2a edição, 2005: 79-129.

Benkler, Yochai. "A Free Irresponsible Press: Wikileaks and the Battle Over the Soul of the Networked Fourth State". Versão preliminar de artigo a ser publicado pela Harvard Civil Rights - Civil Liberties Law Review. Disponível em $<$ http://www.benkler.org/Benkler_Wikileaks_current.pdf $>$; último acesso em 03.01.2013.

Berger, Linda L. "Shielding the Unmedia: using the process of journalism to protect the journalist's privilege in an infinite universe of publication", Houston Law Review 39 (2003): 1373-1411.

Bezanson, Randall. "The Developing Law of Editorial Judgment", Nebraska Law Review 78 (1999): 754-857.

Blackstone, William. Commentaries on the Laws of England. Charles River Editors (versão digital), 2012. Originalmente publicado entre 1765 e 1769.

Blocher, Joseph. "Institutions in the Marketplace of Ideas", Duke Law Journal 57 (2008): 822-889.

Bollinger, Lee C. Images of a Free Press. Chicago: University of Chicago Press, 1994. 
Bradshaw, Tim. "Etos de site tem raiz em cultura dos hackers", Folha de S. Paulo, artigo publicado em 27.07.2010.

Carvalho, Luis Gustavo Grandinetti Castanho de. Liberdade de informação e o direito difuso à informação verdadeira. Rio de Janeiro: Renovar, 2 ed., 2003.

Conselho Editorial, "Protecting the New Media: Application of the Journalist's Privilege to Bloggers", Harvard Law Review 120 (2007): 996-1004.

Cook, Timothy E. "Introductory Essay", in: Timothy E. Cook (org.), Freeing the Presses: The First Amendment in Action. Baton Rouge: Louisiana State University Press, 2006: 1-26.

Dworkin, Ronald. Uma questão de princípio. São Paulo: Martins Fontes, 2001.

Filho, Octávio Frias. "7 vidas do jornalismo", Folha de S. Paulo, artigo publicado em 23.05.2011.

Forde, Kathy Roberts. Literary Journalism on Trial-Masson v. New Yorker and the First Amendment. Amherst: University of Massachusetts Press, 2008.

Fortuna, Felipe. "John Milton e a Liberdade de Imprensa", in: John Milton, Aeropagítica: discurso pela liberdade de imprensa ao Parlamento da Inglaterra. Rio de Janeiro: Topbooks, 1999. 
Franco, Benedito Luiz. Proteção constitucional do sigilo da fonte na comunicação jornalística. São Paulo: Celso Bastos, 1999.

Gant, Scott. We're All Journalists Now: The Transformation of the Press and Reshaping of the Law in the Internet Age. New York: Free Press, 2007.

Horwitz, Paul. “Or Of The Blog”, Nexus 11 (2006): 1-33.

Keller, Bill. "All the aggregation that's fit to aggregate”, New York Times Magazine, artigo publicado em 10.03.2011.

Levy, Leonard W. Emergence of a Free Press. Chicago: Ivan R Dee, 2004.

Lewis, Anthony. “A Preferred Position for Journalism?”, Hofstra Law Review 7 (1979): 595-627.

Make No Law: The Sullivan Case and the First Amendment. New York: Vintage Books, 1992. . Liberdade para as ideias que odiamos. São Paulo: Aracati, 2011.

Lima, Rafael Scavone Bellem de. Otimização de princípios, separação de poderes e segurança jurídica: o conflito entre princípio e regra. Dissertação de mestrado apresentada à Faculdade de Direito da Universidade de São Paulo em 2012.

Logan, David. A. "A reporter's privilege for Twitterers", The Boston Globe, artigo publicado em 26.09.2006. 
Lustosa, Isabel. O nascimento da imprensa brasileira. Rio de Janeiro: Jorge Zahar Editor, 2003.

Magnoli, Demétrio. "Herói sem nenhum caráter", O Estado de S. Paulo, artigo publicado em 23.12.2010.

Martin, Robert. W. T. The Free and Open Press: The Founding of American Democratic Press Liberty, 1640-1800. New York: New York University Press, 2001.

Meiklejon, Alexander. Political Freedom: The constitutional powers of the people. Westport, Connecticut: Greenwood Press, 1979.

Milton, John. Aeropagítica: discurso pela liberdade de imprensa ao Parlamento da Inglaterra. Rio de Janeiro: Topbooks, 1999. Originalmente publicado em 1644.

Mindich, David. Just the facts: how 'objectivity' came to define American journalism. New York: New York University Press, 1998.

Morozov, Evgeny. The Net Delusion: the dark side of internet freedom. New York: Public Affairs, 2011.

Nunes Júnior, Vidal Serrano. Direito e jornalismo. São Paulo: Verbatim, 2011.

Papandrea, Mary-Rose. "Citizen Journalism and the Reporter's Privilege”, Minnesota Law Review 91 (2007): 515-591. 
Peters, Jonathan. "Wikileaks Would Not Qualify to Claim Federal Reporter's Privilege in Any Form”, Federal Communications Law Journal 63 (2011), 668-694. . "Wikileaks show need for a legal 'Watchdog Privilege', Wired, artigo $\begin{array}{lllll}\text { publicado } & \text { em } & \text { 20.05.2011, em }\end{array}$ <http://www.wired.com/threatlevel/2011/05/oped-wikipriviledge>

Pilagallo, Oscar. História da imprensa paulista. São Paulo: Três Estrelas, 2012.

Pinho, Maria Cecília Labate Maiolini Rebello. O sigilo da fonte como garantia da liberdade de informação jornalística. Dissertação de mestrado apresentada à Faculdade de Direito da Universidade de São Paulo em 2007.

Schauer, Frederick. "Towards an Institutional First Amendment", Minnesota Law Review 89 (2005): 1256-1279. . "Principles, Institutions and First Amendment", Harvard Law Review 112 (1999): 84-120.

Silva, Carlos Eduardo Lins da. Mil dias: seis mil dias depois. São Paulo: Publifolha, 2005.

Silva, José Afonso da. Curso de Direito Constitucional Positivo. São Paulo: Malheiros, $20^{\mathrm{a}}$ edição, 2002.

Silva, Virgílio Afonso da. Direitos fundamentais: conteúdo essencial, restrições e eficácia. São Paulo: Malheiros, 2008. 
Stewart, Potter. "Or Of The Press", Hastings Law Journal 26 (1975): 631-637.

Toland, Carol J. "Internet Journalists and the Reporter's Privilege: Providing Protection for Online Periodicals", The Kansas Law Review 57 (2008): p. 461-490. 